UNIVERSIDADE DE SÃO PAULO

FACULDADE DE FILOSOFIA, LETRAS E CIÊNCIAS HUMANAS DEPARTAMENTO DE GEOGRAFIA PROGRAMA DE PÓS-GRADUAÇÃO EM GEOGRAFIA FÍSICA

\title{
UM ENSAIO METODOLÓGICO SOBRE A QUALIDADE DE VIDA NO DISTRITO DE CACHOEIRINHA, ZONA NORTE DA CIDADE DE SÃO PAULO - SP.
}

Marilia Araujo Roggero 
UNIVERSIDADE DE SÃO PAULO

FACULDADE DE FILOSOFIA, LETRAS E CIÊNCIAS HUMANAS

DEPARTAMENTO DE GEOGRAFIA

PROGRAMA DE PÓS-GRADUAÇÃO EM GEOGRAFIA FÍSICA

\section{UM ENSAIO METODOLÓGICO SOBRE A QUALIDADE DE VIDA NO DISTRITO DE CACHOEIRINHA, ZONA NORTE DA CIDADE DE SÃO PAULO - SP.}

Dissertação apresentada ao Programa de PósGraduação em Geografia Física, do Departamento de Geografia da Faculdade de Filosofia, Letras e Ciências Humanas da Universidade de São Paulo, para a obtenção do título de Mestre.

Orientador: Prof. Dr. Ailton Luchiari

Marilia Araujo Roggero 
Para meus queridos pais

Luiz Attilio Roggero

Ilsa Araujo Roggero 


\section{AGRADECIMENTOS}

Agradeço do Professor Ailton Luchiari pela orientação, confiança depositada, compreensão e apoio nos trabalhos de campo.

Ao Cnpq pelo auxílio financeiro.

À minha família por acreditar em mim, me incentivando e apoiando em todos os momentos da minha vida.

À amiga Taiane pela revisão do Abstract, pelo apoio nos momentos difíceis, pela amizade sincera.

Aos amigos Amanda e Ben pela revisão do Abstract.

À amiga Renata pela leitura, apontamento de sugestões e apoio principalmente na parte inicial do presente estudo.

À amiga Rosi, pelo apoio e amizade sinceros e revisão final do trabalho.

Ao pessoal da Consultoria Paulista pela confiança depositada e pelo apoio.

À Rúbia, colega com quem esclareci muitas das dúvidas no início da pesquisa.

Ao Eric, colega que me concedeu algumas fotografias e material pesquisado da área de estudo.

Aos funcionários da seção de alunos da pós-graduação, sempre prestativos.

Ao meu primo Rodrigo por ter me acompanhado nos trabalhos de campo.

À amiga Mariana, por ter me ajudado na formatação final do trabalho. 


\section{LISTA DE FIGURAS}

Figura 1: Esquema da utilização da matemática para resolução do problema $\quad 7$

Figura 2: Arquitetura de um sistema de informações geográficas (SIG) 12

Figura 3: Árvore de decisões $\quad 23$

Figura 4: Intervenções na Paisagem Urbana de São Paulo 29

Figura 5: Estrutura, fonte de dados e indicadores para o Índice de Qualidade de Vida Urbana 40

Figura 6: Comparação dos índices de habitação tipo cômodo na Cachoeirinha e 54

na Cidade de São Paulo.

Figura 7: Comparação dos índices de domicílios alugados na Cachoeirinha e 56

na Cidade de São Paulo.

Figura 8: Comparação dos índices de domicílios quitados na Cachoeirinha e 57

na Cidade de São Paulo.

Figura 9: Comparação entre o abastecimento de água na Cachoeirinha e

60

na Cidade de São Paulo.

Figura 10: Comparação entre o esgotamento sanitário na Cachoeirinha e

na Cidade de São Paulo.

Figura 11: Comparação entre a coleta de lixo na Cachoeirinha e

na Cidade de São Paulo.

Figura 13: Comparação entre a porcentagem dos chefes de família alfabetizados

na Cachoeirinha e na Cidade de São Paulo.

Figura 14: Comparação entre a porcentagem dos chefes de família

com ensino fundamental completo na Cachoeirinha e na Cidade de São Paulo. 


\section{LISTA DE FOTOS}

Foto 1: Operação Defesa das águas 19/07/2007 52

Foto 2: Córrego do bispo - Bairro Jardim Peri, limite com o Parque Estadual da Cantareira 52

Foto 3: Córrego do bispo - Bairro Jardim Peri, do lado direito da foto as autoconstruções 53

e do lado esquerdo as árvores da APA.

Foto 4: Conjunto Habitacional da Vila Nova Cachoeirinha ao fundo (Prédios Azuis). 83

Foto 5: Prédio do condomínio Localizado na Avenida Santa Inês 84

Foto 6: Conjunto Residencial Brasil 1

Foto 7: Casas Maiores em uma rua tranqüila (Rua Angola) do distrito de Cachoeirinha 85

Foto 8: Vista das casas desta zona residencial (Av. Inajar de Souza) 86

Foto 9: Vista dos prédios da Cohab Jardim Antártica 87

Foto 10: Casas da Rua Caiena próximo à Rua Antônio Amorim 88

Foto 11: Sobrados antigos que fazem parte dessa zona residencial localizados na pracinha 89 da Rua Maracaia próximos à Rua dos Patis

Foto 12: Sobrados da Rua Almir Rodrigues 90

Foto 13: Edifícios que compõem essa zona residencial homogênea. Foto tirada da 91 esquina da Rua dos Patis x Rua Franklin Amaral

Foto 14: Favela localizada na beira do córrego, bem próximo à base da Serra da Cantareira, 92 vista ao fundo da fotografia 


\section{LISTA DE MAPAS}

Mapa 1: Distrito de Cachoeirinha - São Paulo, Imagem Ikonos $2002 \quad 16$

Mapa 2: Localização da Área de Estudo na Região Metropolitana de São Paulo 47

Mapa 3: Localização da Área de Estudo no município de São Paulo 48

Mapa 4: Localização dos Bairros no Distrito de Cachoeirinha 49

Mapa 5: Uso do Solo e Cobertura Vegetal $\quad 80$

Mapa 6: Proporção de Casas e Edifícios no Distrito de Cachoeirinha 81

Mapa 7: Zonas Residenciais Homogêneas e seus códigos 93

Mapa 8: Resultado da primeira análise de agrupamento 99

Mapa 9: Zonas Residenciais agrupadas, segundo os critérios demonstrados na metodologia $\quad 100$

Mapa 10: Agrupamentos Zonas Residenciais e Setores Censitários 101

Mapa 11: Síntese Final elaborada após as análises multivariadas 102 


\section{LISTA DE TABELAS E GRÁFICOS}

Tabela 1: Principais características das Imagens IKONOS II 15

$\begin{array}{ll}\text { Tabela 2: Metodologias e seus respectivos indicadores voltados ao } & 68\end{array}$ mapeamento da Qualidade de Vida

Tabela 3: Indicadores construídos a partir de variáveis do censo demográfico $\quad 70$

Tabela 4: Indicadores selecionados para a análise fatorial 72

Tabela 5: Total da Variância Explicada $\quad 94$

Tabela 6: Componentes da Matrix Rotacionada $\quad 95$

$\begin{array}{ll}\text { Tabela 7: Distribuição dos Clusters } & 97\end{array}$

Tabela 8: Distribuição dos Clusters - final 98

$\begin{array}{ll}\text { Gráfico 1: Tamanho dos Clusters gerados } & 97\end{array}$

Gráfico 2: Tamanho dos Clusters gerados - final 98 


\section{SIGLAS}

CONAMA - CONSELHO NACIONAL DE MEIO AMBIENTE

IBGE - INSTITUTO BRASILEIRO DE GEOGRAFIA E ESTATÍSTICA

IDH - ÍNDICE DE DESENVOLVIMENTO HUMANO

IDH-M - ÍNDICE DE DESENVOLVIMENTO HUMANO MUNICIPAL

lex - ÍNDICE DE EXLUSÃO/INCLUSÃO SOCIAL

IPPUC - INSTITUTO DE PESQUISA DE PLANEJAMENTO URBANO

IPRS - ÍNDICE PAULISTA DE RESPONSABILIDADE SOCIAL

IPVS - ÍNDICE PAULISTA DE VULNERABILIDADE SOCIAL

IQVU - ÍNDICE DE QUALIDADE DE VIDA URBANA

ISSa - ÍNDICE SOCIOAMBIENTAL

ISSQV - ÍNDICE SINTÉTICO DE SATISFAÇÃO DA QUALIDADE DE VIDA

IVS - ÍNDICE DE VULNERABILIDADE SOCIAL

PIB - PRODUTO INTERNO BRUTO

PUC - SP PONTIFÍCIA UNIVERSIDADE CATÓLICA - SÃO PAULO

PNUD - PROGRAMA DAS NAÇÕES UNIDAS PARA O DESENVOLVIMENTO

ONU - ORGANIZAÇÃO DAS NAÇÕES UNIDAS

SEADE - SISTEMA ESTADUAL DE ANÁLISE DE DADOS

SIG - SISTEMAS DE INFORMAÇÕES GEOGRÁFICAS

SVMA - SECRETARIA DO VERDE E MEIO AMBIENTE

UNESP - UNIVERSIDADE PAULISTA JÚLIO DE MESQUITA FILHO 


\section{RESUMO}

A qualidade de vida urbana tem sido estudada pelas mais diversas áreas do conhecimento e é uma temática complexa. O tema qualidade de vida envolve questões multidisciplinares apresentadas por meio de perspectivas diferenciadas, de acordo com a relevância do momento histórico, das condições sociais, bem como da ideologia dominante a partir dos objetivos propostos. Isso posto, a abordagem adotada no presente estudo está focada na satisfação das necessidades básicas da população, de modo a garantir o pleno desenvolvimento físico, mental e social. Para isso, foram abordadas quatro dimensões: condições de saneamento, situação socioeconômica e demografia, por meio da utilização dos dados censitários (IBGE, 2000) e as zonas residenciais homogêneas, por meio de técnicas de interpretação de imagens de satélite com alta resolução espacial. Para a espacialização e processamento dos dados quantitativos e qualitativos foram utilizadas técnicas de Geoprocessamento, por meio do uso de um Sistema de Informação Geográfica e técnicas estatísticas, que garantiram a distribuição espacial dos dados levantados. A partir dos resultados alcançados por meio dessas técnicas, foi possível elaborar o mapa síntese da qualidade de vida do distrito da Cachoeirinha, zona norte da cidade de São Paulo.

\section{PALAVRAS - CHAVE}

Qualidade de vida, Sistemas de Informações Geográficas, Estatística multivariada, Zonas residenciais homogêneas, Geoprocessamento. 


\begin{abstract}
The quality of urban life has been studied in various areas of academic specialization and is a complex theme. The subject's quality of life involves multidisciplinary questions presented with different perspectives, according to the relevance of the historical moment, social conditions, as well as the dominant ideology shaping the objectives in question. The approach adopted in the present study is focused on the satisfaction of the basics needs of the population, in order to guarantee complete physical, mental and social development. For this, four dimensions were considered: conditions of sanitation; the socioeconomic situation and demography; using data of the last demographic Census in 2000 (IBGE, 2000); and homogeneous residential zones, by means of technical interpretation of satellite images with high spatial resolution. For the spatial results and processing of quantitative and qualitative data, techniques of Geoprocessing had been used, using Geographic Information System and statistical techniques, which had guaranteed the spatial distribution of the listed data. From the results obtained with these techniques, it was possible to elaborate the map synthesis of the quality of life of Cachoeirinha District, northern zone of São Paulo, Brazil.
\end{abstract}

\title{
KEY - WORDS
}

Quality of life, Geographic Information System, Multivariate statistics, Homogeneous residential zones, Geoprocessing. 


\section{SUMÁRIO}

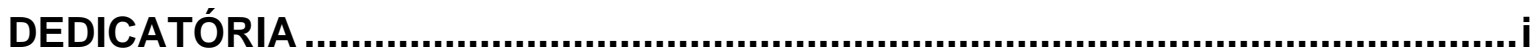

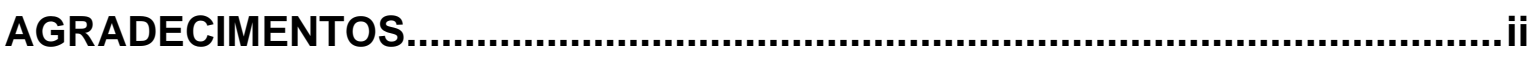

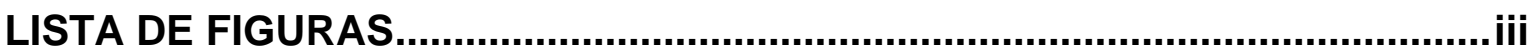

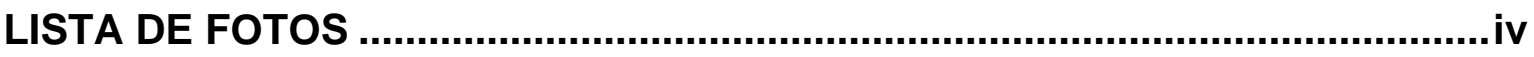

LISTA DE MAPAS ............................................................................................

LISTA DE TABELAS E GRÁFICOS............................................................vi

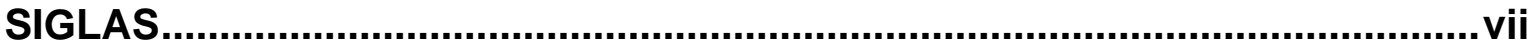

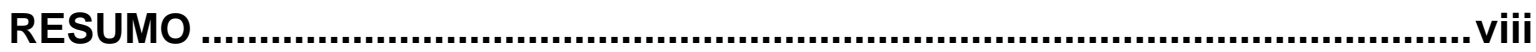

ABSTRACT

CAPÍTULO 1

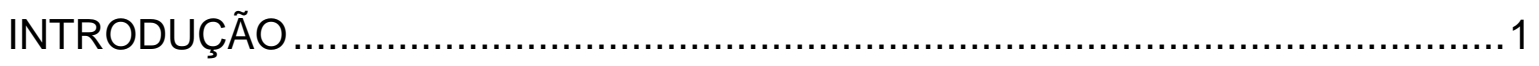

CAPÍTULO 2

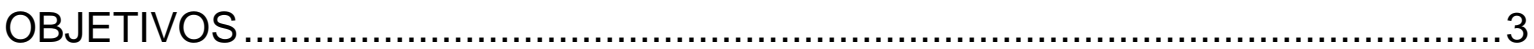

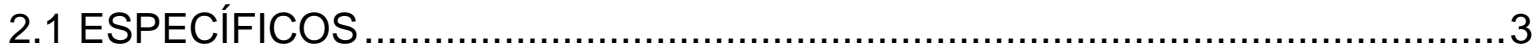

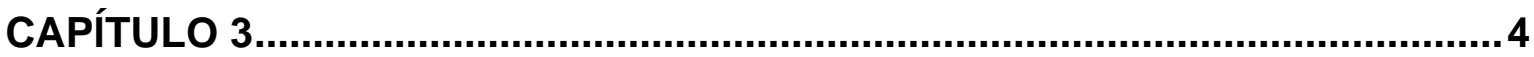

FUNDAMENTAÇÃO TEÓRICA E METODOLÓGICA …................................ 4

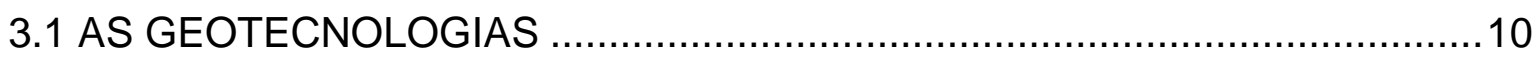

3.1.1 SISTEMAS DE INFORMAÇÕES GEOGRÁFICAS (SIG)...................10

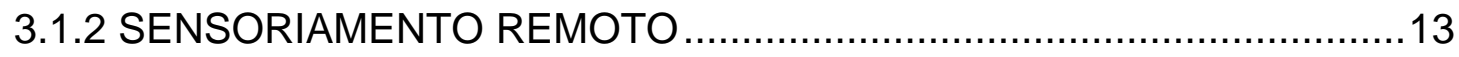

3.1.3 IMAGENS DE SATÉLITE: IKONOS II ............................................14

3.1.4 SENSORIAMENTO REMOTO E ESTUDOS INTRA-URBANOS..........17

3.2 ESTUDOS URBANOS E A CIDADE DE SÃO PAULO …..............................24

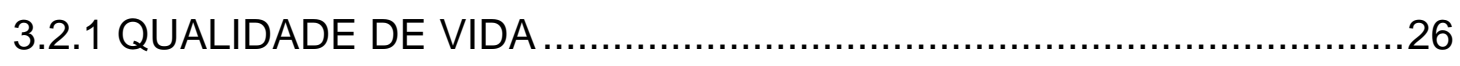

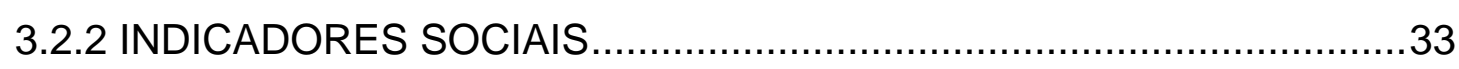

3.2.3 EVOLUÇÃO DEMOGRÁFICA DA CIDADE DE SÃO PAULO E OS

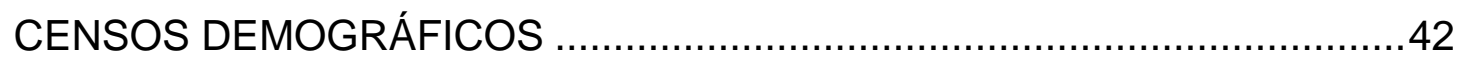

CAPÍTULO 4

ÁREA DE ESTUDO

4.1 CARACTERÍSTICAS DO DISTRITO DE CACHOEIRINHA, SEGUNDO

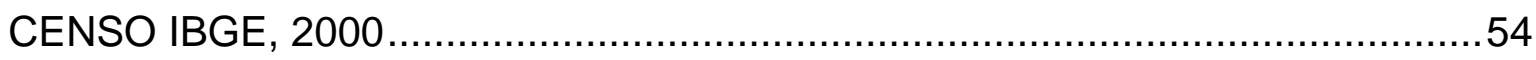

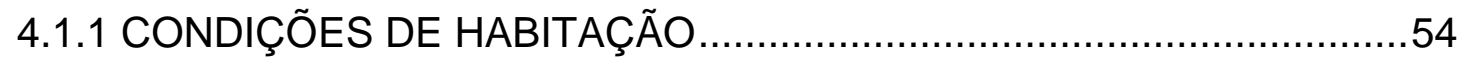

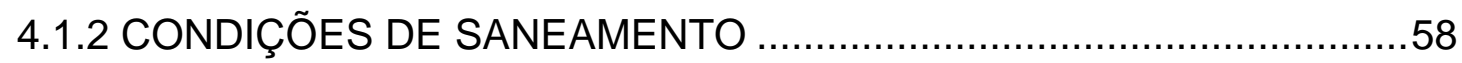

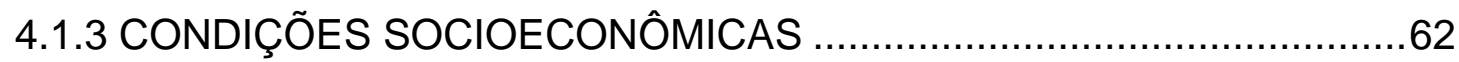




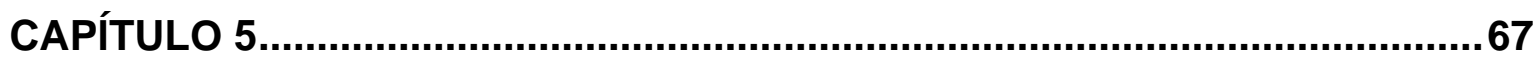

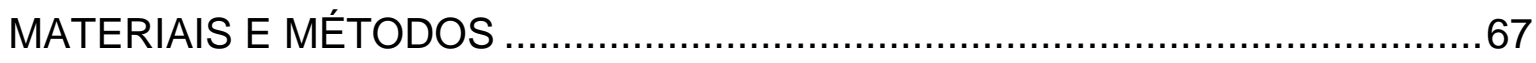

5.1 METODOLOGIA

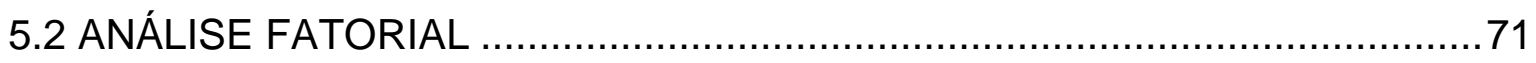

5.2.1 ANÁLISE DE AGRUPAMENTO (CLUSTERS ANALYSIS) …..............72

5.3 INTERPRETAÇÃO VISUAL DAS IMAGENS IKONOS ……..........................73

5.3.1 ELABORAÇÃO DE CHAVES DE INTERPRETAÇÃO …......................74

5.3.2 DETERMINAÇÃO DAS ZONAS RESIDENCIAIS HOMOGÊNEAS ......76

5.3.3 A ANÁLISE DE AGRUPAMENTO FINAL ……..............................77

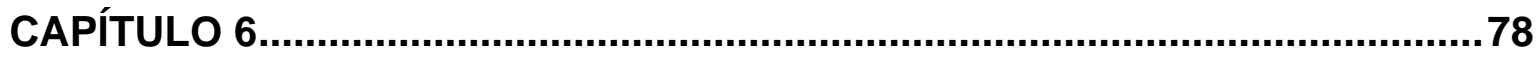

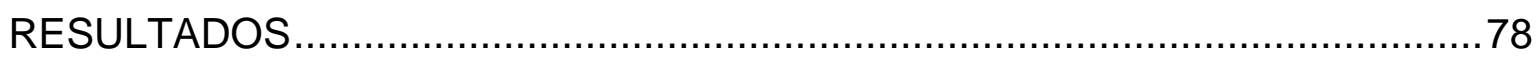

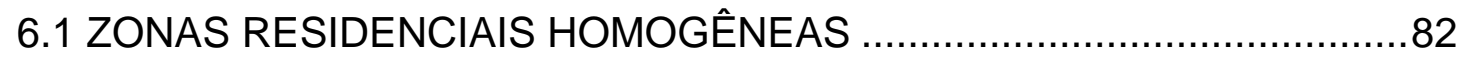

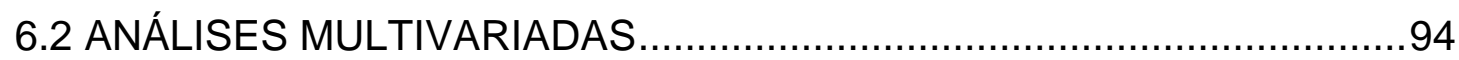

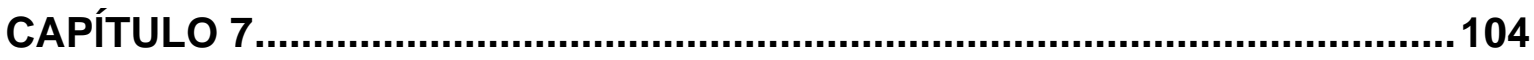

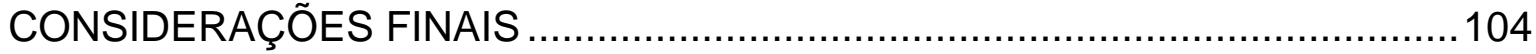

CAPÍTULO 8

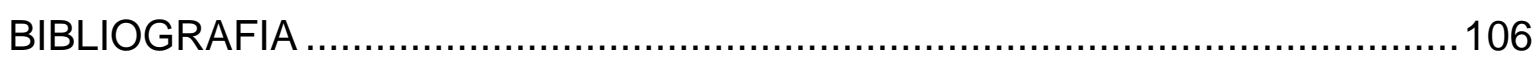

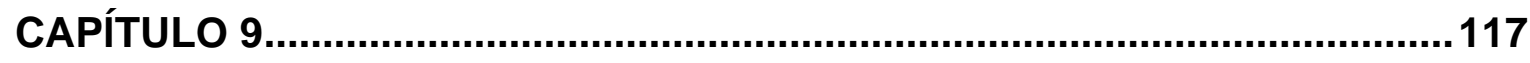

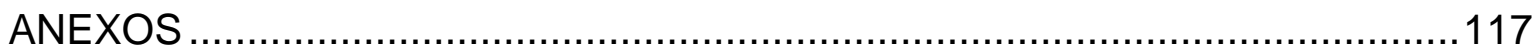




\section{CAPÍTULO 1}

\section{INTRODUÇÃO}

O espaço urbano é o local onde grupos sociais vivem, se reproduzem e o reproduzem, ou seja, um espaço dinâmico em constante transformação. Deste modo, as formas criadas no interior urbano condizem com as funções que necessitam ser realizadas nas mesmas como moradias, serviços, indústrias e comércio. É certo também que através da dinâmica urbana estas formas sofrem diversas transformações em seu uso: isto é, moradias viram escritórios, indústrias transformam-se em centro culturais e assim por diante. A identificação das formas urbanas através do agrupamento pode definir zonas dentro das cidades tais como: zonas residenciais, comerciais e industriais.

As modificações na metrópole em geral geram transformações no tecido urbano que podem ser representadas através dos mapas. De acordo com Luchiari (2005), os geógrafos têm preocupações acerca destas representações que estão diretamente relacionadas com a distribuição dos fenômenos que ocorrem na superfície da Terra.

O Sensoriamento Remoto e suas técnicas vêm constituindo um instrumento imprescindível para os profissionais que como o geógrafo estuda o espaço urbano. A interação entre sistemas de Informações geográficas (SIG) e sensoriamento remoto faz-se também indispensável, pois hoje se exige a atualização periódica de bases de dados que representem a situação atual. Dados básicos para o planejamento precisam ser atualizados constantemente e na medida do possível com qualidade na resolução. Isso significa que um mapa digital hoje se torna desatualizado se o mesmo não representar uma junção da situação presente, fundida com uma base de dados também atualizada.

As bordas urbanas conforme a região da área de estudo do distrito de Cachoeirinha, que assim é considerada devido à barreira física representada pela Serra da Cantareira e sua área de preservação, apresentam mais do que qualquer outra parte das metrópoles uma dinâmica de crescimento populacional e expansão urbana diversificadas. O aumento da segregação residencial em São Paulo está diretamente relacionado a questões de fronteira urbana, denominada 
por Torres (2005) como uma categoria de análise das ciências sociais não inédita, principalmente na área ligada ao planejamento urbano. O autor questiona o fato de não designarmos essas áreas apenas como periferias ou áreas periurbanas, e que embora na cidade de São Paulo sejam áreas predominantemente externas, ou seja, que extrapolam os limites da região metropolitana de São Paulo, entende-se neste estudo que a região da Cachoeirinha insere-se diretamente em área de fronteira urbana, inserida no município de São Paulo, mas que encontra sua expansão limitada pela barreira física representada pelo Parque Estadual da Cantareira. De acordo com Marques (2005) essa região periférica, denominada de fronteira urbana, cresceu de 1990 até 2000 passando a atingir 30\% da mancha urbana com quase cinco milhões de habitantes. A região de periferia definida por Torres (2005) como fronteira urbana da Região Metropolitana de São Paulo, continua a receber migrantes, a crescer a taxas aceleradas e a apresentar uma estrutura fundiária precária com expansão de favelas e loteamentos clandestinos. Além de todas as questões apresentadas acima, essas áreas apresentam problemas ambientais, caracterizados por áreas de riscos sendo, portanto prejudiciais para a população que lá vive.

As áreas periféricas das grandes cidades brasileiras apesar de serem foco das mais diversas pesquisas, pouco têm sido analisadas com relação a sua qualidade de vida. Sendo o Censo Demográfico realizado de dez em dez anos, com um orçamento oneroso, por volta de quinhentos milhões de reais (IBGE, 2000); envolvendo grande quantidade de recursos humanos e materiais nos levantamentos, na análise dos dados, e tendo enfoques também em outros aspectos que não à qualidade de vida, torna-se necessário do ponto de vista do planejamento, mais especificamente do Urbano, levantamentos mais freqüentes e de baixo custo. As zonas periféricas por serem mais carentes e uma das mais dinâmicas das cidades merecem uma atenção maior e, portanto, foi escolhida para testar o potencial das técnicas e instrumentos de sensoriamento remoto, geoprocessamento e sua aplicabilidade ao estudo da qualidade de vida.

O presente estudo pretende também colaborar para a tomada de decisões de políticas públicas municipais que já utilizam como unidade de análise os distritos, justificando assim, o recorte espacial feito na pesquisa. 


\section{CAPÍTULO 2}

\section{OBJETIVOS}

O objetivo central deste trabalho foi desenvolver uma metodologia para analisar a qualidade de vida urbana do distrito de Cachoeirinha, visando a construção de um mapa síntese. Essa metodologia foi desenvolvida com o auxílio de técnicas de Sensoriamento Remoto e Estatística Multivariada.

\subsection{ESPECÍFICOS}

- Avaliar as informações que podem ser extraídas das imagens IKONOS II coloridas, para análise de uma região periférica, como é considerada a área de estudo.

- Analisar o potencial das técnicas e instrumentos de sensoriamento remoto e a estatística multivariada na construção de um mapa síntese de qualidade de vida, voltado ao planejamento Ambiental/Urbano.

- Analisar a metodologia desenvolvida para análise da qualidade de vida urbana e compará-la a outras metodologias pesquisadas. 


\section{CAPÍTULO 3}

\section{FUNDAMENTAÇÃO TEÓRICA E METODOLÓGICA}

A metodologia desenvolvida na presente pesquisa baseou-se na linha de pesquisa da Geografia Teorética, essa linha de pesquisa em Geografia é também conhecida como Geografia Quantitativa e está inserida no contexto da Nova Geografia.

Segundo Carlos (1994), a preocupação com o espaço permeia e sempre permeou os estudos geográficos, mas nem sempre o espaço foi conceituado e estudado do mesmo modo pelos geógrafos. Estas concepções diferentes, segundo a autora, por vezes desemboca na noção de espaço como palco da atividade humana, algo comum no movimento da Nova Geografia. Nesse sentido, a preocupação com a fundamentação teórico-metodológica precisa se impor. $\mathrm{Na}$ Geografia, estudos principalmente urbanos, certamente já ultrapassaram a barreira monográfica da descrição. O espaço geográfico não é mais visto como algo inerte, eterno ou natural ele é um produto concreto das relações sociais historicamente determinadas.

Ao tentarmos construir indicadores para analisar um fenômeno que se concretiza no espaço geográfico, tal como o da qualidade de vida urbana, a dimensão do espaço como palco da vida humana não é pertinente. Nosso olhar geográfico, capturado por meio de interpretação de imagens, análise de dados, nos permite compreender o modo como a sociedade organiza seu espaço, sua vida e como estes se apresentam de maneira contraditória, sem perder de vista a relação homem-meio, tendo o primeiro como o produtor desse espaço.

Na Geografia, as raízes da quantificação segundo Chilson (1975, apud in Santos, 2002) não estão apoiadas apenas na estatística moderna, mas sim, na ciência cartográfica. Após a Segunda Guerra Mundial as ciências sofreram transformações e, conseqüentemente, a Geografia também sofreu esse impacto. A emergência de novas discussões e reflexões oriundas das mais variadas disciplinas e dos mais diversos discursos, impulsionou a origem de uma Nova Geografia, manifestada principalmente por meio da quantificação. Foi nos anos 70 que se iniciou a propagação da Nova Geografia no Brasil a partir de instituições 
como IBGE, Universidade Federal do Rio de Janeiro e Universidade Paulista Júlio de Mesquita Filho - Rio Claro (UNESP). O IBGE, em 1972, publica um texto onde enfatiza a importância da formulação de hipóteses e do embasamento estatístico para validá-las por meio de um conjunto de técnicas computacionais.

Para Faissol (1972), trata-se de um novo paradigma regional resultante dos conflitos teóricos e metodológicos enfrentados pela ciência Geográfica. Já Santos (2002) afirma que neste aspecto, paradigma e método são indissociáveis, pois, os geógrafos sempre procuraram apoiar suas afirmações em estatísticas ou inquéritos elaborados por eles mesmos. Segundo Archela (2007), o tratamento matemático e estatístico dos dados refletiu em novas modalidades de representação cartográfica, já que trabalhos que utilizam tais métodos apresentam resultados baseados em gráficos e mapas um tanto complexos, que exigem leitura do texto além de conhecimento matemático e estatístico para a sua compreensão.

De acordo com Evangelista, (2006) a Geografia quantitativa significou uma alteração no próprio sentido de se conceber a Geografia. Para esse mesmo autor, muitas das transformações pelas quais a Geografia brasileira passou nos últimos anos, dentre as quais a busca por novas concepções teóricas e metodológicas, foi semeada pela Geografia Quantitativa.

O desenvolvimento de uma visão sistêmica também foi de grande importância para o desenvolvimento da Geografia Quantitativa, tendo em vista a necessidade de modelos. Os modelos são instrumentos de auxílio à análise da abordagem sistêmica, eles representam características do sistema. Nos estudos das cidades, os modelos são de fundamental importância para se conceber a situação atual, antecipar cenários futuros antes de qualquer intervenção de planejamento.

De acordo com Gerardi \& Silva (1981), a revolução quantitativa iniciada na Geografia nos anos cinqüenta é hoje melhor disseminada na ciência; e aliada ao conhecimento da natureza do problema pesquisado, deve estimular o pesquisador a propor de maneira clara e objetiva suas hipóteses de modo a coletar e triar os dados que são mais relevantes para testá-las.

Quando o geógrafo se propõe a trabalhar com dados, o volume de informação a ser considerado de informação é geralmente grande, levando à necessidade de manipulação e compreensão dos dados além da transformação 
da massa de informação, por meios propiciados pela análise quantitativa. A quantificação é uma diretriz metodológica que permite não só a explicação de um problema em questão como também o enriquecimento teórico-conceitual e conseqüentemente generalizações em etapas posteriores do trabalho. A quantificação é um meio e não um fim para chegar a conclusões.

Câmara et al. (2000), relata que a base da Geografia Quantitativa é a busca da aplicação nos estudos geográficos do método hipotético-dedutivo que caracteriza as ciências naturais. A lógica desse método é a de que existe uma realidade externa à nossa existência e que esta pode ser capturada de forma aproximada através dos princípios da lógica e da matemática. A Geografia sob a ótica da escola teorética, propõe a construção de modelos a serem utilizados nas análises geográficas. Esses modelos devem ser validados e verificados com levantamentos realizados em campo e a partir de técnicas estatísticas; isso posto, a escola da Geografia Quantitativa demonstra grande ênfase em técnicas de análise espacial e Geoestatística (Bailey and Gattrel 1995 apud in Câmara, 2000).

Harvey (1969) é quem detalha de forma elucidativa o método hipotéticodedutivo abordado por Câmara et. al (2000), o autor exemplifica o método como sendo um sistema que captura como a realidade se estrutura, para depois capturar imagens dessa realidade e posteriormente identificar modelos. O consenso básico é a elaboração de um critério que pode ser desenvolvido com respeito à explicação em Geografia, tendo em vista analisar as várias maneiras com as quais nós podemos assegurar uma explicação consistente dessa ciência. Para o autor é também tarefa da Geografia considerar a aplicação de um critério para explicar um fenômeno geográfico conforme pode ser verificado no quadro a seguir: 
Figura 1: Esquema da utilização da matemática para resolução do problema.

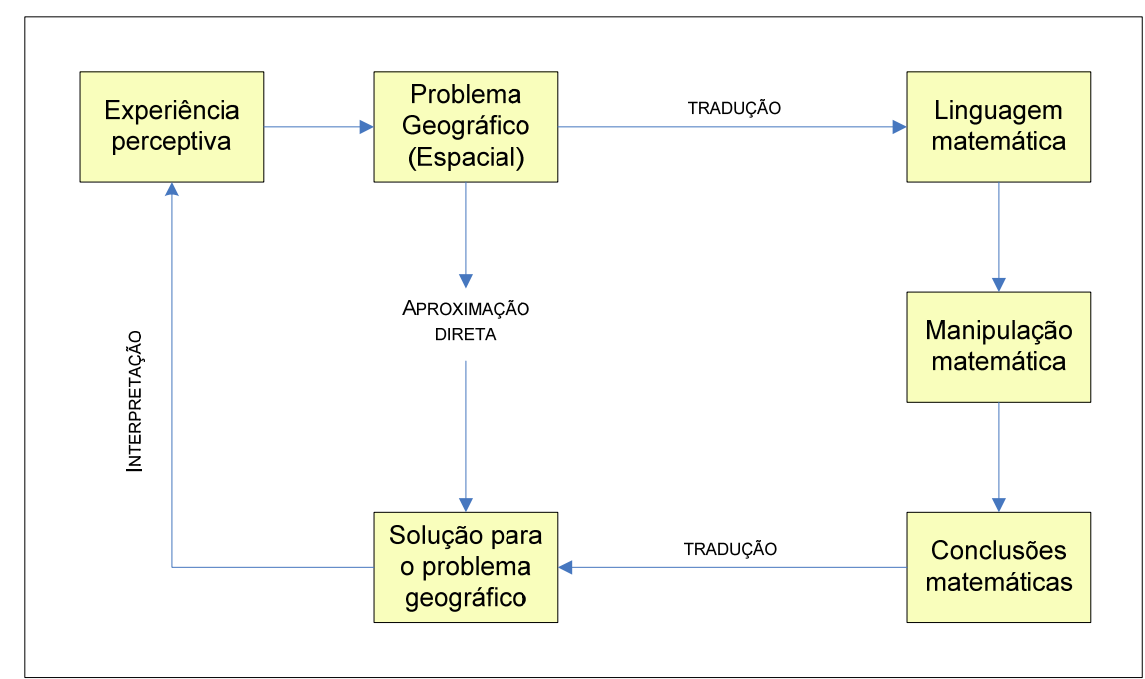

Fonte: Extraído do livro Explanation in Geography, página 184.

De acordo com Lacoste (1976), a Geografia deve estar consciente de que analisando o espaço, na verdade os geógrafos ( $\mathrm{sic}^{\star}$ ) devem estar conscientes, pois, ao analisarmos o espaço, fornecemos informações que nos permitem agir sobre os homens que vivem nesse espaço. A contradição é expressa pelo autor da seguinte maneira: quanto mais uma pesquisa estiver em condições de apreender as realidades, mais ela perceberá as diversas contradições existentes, e complementa, quanto maior o valor científico de uma análise, maior a quantidade de informações preciosas que lhe permitirão agir de forma eficiente sobre o grupo estudado, mas complementa afirmando que isso nem sempre ocorre.

Outra corrente teórica que embasou o presente estudo foi a Ecologia Humana que tem como sua hipótese fundamental a existência de uma correlação entre a ordem social e a distância física e entre a igualdade social e a proximidade residencial (Palem, 1975 apud in Souza 2004).

A Ecologia Humana é uma corrente teórica da Sociologia, proveniente da Escola de Chicago, que estuda processos de competição e as relações que deles provenham de homem para homem, de grupos humanos para grupos humanos e de instituições para instituições e como estas se revelam por índices físicos, isto é, no espaço. (Pierson, 1948)

O maior expoente dessa corrente teórica é Park (apud in Pierson, 1948), que considera a cidade não somente em seus aspectos físicos e mecânicos, mas 
sobretudo, como produto da natureza humana, na qual apresenta-se envolvida com os processos vitais, que são a organização do meio, as ocupações e a cultura.

Com relação à distribuição dos indivíduos e, consequentemente, seus reflexos nas morfologias das cidades, a Teoria da Ecologia Humana traz estudiosos de destaque, alguns dos quais apresentados a seguir.

Corrêa (1995 apud in Souza, 2004) identificou que o sociólogo Ernest W. Burgess efetuou uma das primeiras tentativas de aplicar princípios teóricos da Ecologia Vegetal e animal ao estudo das comunidades urbanas, baseando-se no estudo de grupos e não de indivíduos. A Ecologia Humana dentro da sociologia tem seu foco voltado para as questões de adaptação ao habitat através da organização social. Burgess demonstrou em seu trabalho, segundo Amorim Filho (2005) que a questão social e a questão da moradia estavam de certa forma relacionadas dentro da estrutura espacial da cidade.

O modelo de Burgess das cinco zonas concêntricas demonstra a importância dada para aos aspectos econômicos, sociológicos e demográficos, com algumas referências a determinadas funções e a aspectos específicos da morfologia urbana.

O economista Homer Hyot valeu-se em seu esquema teórico-conceitual de análise de várias contribuições de Burgess. Entretanto, sua interpretação foi baseada em dados e conceitos econômicos e na pressuposição de processos, relações e fatores de natureza sócio-econômica para a explicação da estrutura espacial da cidade. Sendo Hyot o principal economista de uma empresa federal de moradia dos EUA, com livre acesso a um conjunto de dados sobre as cidades americanas, sua reflexão volta-se mais para aluguel, o que lhe revela detalhes importantes sobre uma série de outras características das moradias. (Corrêa, 2005)

Os geógrafos Harris e Ullman, nos anos 40 e 50 do século passado, desenvolveram o esquema dos núcleos múltiplos. Este modelo adota elementos presentes nos dois anteriores (Burgess e Hyot) e acrescenta outros aspectos de destaque tais como, a forma com que a estrutura de utilização do solo de uma cidade se articula mais frequentemente mais ao redor dos núcleos múltiplos e descontínuos do que ao redor de um núcleo simples como postulavam os modelos anteriores. Certamente as características do núcleo principal e dos 
outros núcleos vão variar em função do tamanho, hierarquia e dinamismo das cidades consideradas.

Estes primeiros modelos de zoneamento morfológico-funcional do espaço urbano, como denomina Amorim Filho (2005) são considerados clássicos e foram elaborados no início do século passado nos Estados Unidos.

Corrêa (2005) também pesquisador de morfologia de cidades, detalha em seu trabalho "O Espaço Urbano" as subunidades da área central das grandes cidades, assim como a zona periférica de um núcleo central, conceito que pode ser estendido a qualquer área periférica de grandes cidades brasileiras:

Região com uso semi-intensivo do solo onde as principais atividades são: comércio atacadista, armazenagem, indústrias leves. Além disso, caracteriza-se por ampla escala horizontal, área residencial de baixo status social, focos de transportes inter-regionais onde se localizam terminais rodoviários, depósitos e garagens.

Já Torres (2005) mais voltado às questões da distribuição espacial dos grupos sociais, explicita no trabalho "São Paulo: Segregação, Pobreza e Desigualdades Sociais (2005)" o debate sobre a heterogeneidade da periferia e utiliza a expressão fronteira urbana como "metáfora poderosa do ponto de vista analítico" (2005:105) para expressar espaços em transição. Para Torres, as fronteiras urbanas se caracterizam por serem:

Regiões com alta taxa de crescimento demográfico e com substancial migração; apresentam infra-estrutura precária e em construção, com pouca presença do Estado; Funcionam como uma "válvula de escape" e concentram a população que não têm lugar nas áreas urbanas consolidadas; local onde os conflitos são intensos sobre a posse da terra e também por ocuparem áreas de preservação florestal e de mananciais.

Corrêa (2005) também apresenta uma definição de segregação social. Para ele os processos que definem a divisão social do espaço definirão também a divisão econômica. Segundo o autor citado, o conceito de segregação residencial foi criado a partir da Escola de Chicago, na qual se insere a Ecologia Humana e a partir da qual surgiram os primeiros modelos de zoneamento morfológico funcional. Esta pesquisa, no entanto, não pretende ser um estudo morfológico, tendo em vista a escolha da área de estudo e seu objetivo. Entretanto, fez-se uso 
de conceitos e definições importantes de autores citados que trabalham com esta proposta teórica para auxiliar na classificação de zonas homogêneas.

\subsection{AS GEOTECNOLOGIAS}

Dentre os estudos urbanos realizados nas mais diversas áreas do conhecimento, independente do enfoque dado pelo pesquisador, é importante ressaltar na maioria das vezes a necessidade de manipulação, integração, análise de dados oriundos das mais diversas formas e fontes. Atualmente, os avanços tecnológicos nas áreas de hardware e software têm possibilitado e beneficiado pesquisas por meio do desenvolvimento de procedimentos e métodos que auxiliam a análise de dados espaciais. Os estudos urbanos têm sido nesta última década, um dos mais beneficiados devido ao detalhamento dos dados/informações que hoje já estão disponíveis como, por exemplo, as imagens IKONOS II (2002) de alta resolução espacial, conseqüência direta da liberação tecnológica promovida pelo governo norte-americano em 1994.

\subsubsection{SISTEMAS DE INFORMAÇÕES GEOGRÁFICAS (SIG)}

O geoprocessamento surgiu nos anos 50 na Inglaterra e nos Estados Unidos, devido à necessidade de se automatizar parte do processamento de dados com características espaciais. Entretanto, estes sistemas ainda não eram classificados como sistemas de informação naquele momento. Atualmente, o termo geoprocessamento pode ser considerado como um conjunto de instrumentos ou recursos disponibilizados pelas tecnologias que engloba 0 sistema de posicionamento global, o Sensoriamento Remoto, o Sistema de Informações Geográficas (SIG) e a cartografia digital.

Os primeiros Sistemas de Informações Geográficas surgiram no Canadá, na década de 1960, e faziam parte de um programa governamental voltado à criação de um inventário de recursos naturais.

Desde a década de 80 do século passado até os dias de hoje a tecnologia de sistemas de informações geográficos vêm se desenvolvendo de forma significativa e acelerada. Os GIS (do inglês, Geographic Information System) ou SIG foram e estão sendo cada vez mais beneficiados pelos avanços da área de 
informática, que proporciona a popularização destas ferramentas e conseqüentemente, a diminuição de custos.

Segundo Oliveira (2006), existe uma diversidade de definições de SIG e estas refletem a multiplicidade de usos possíveis destes sistemas de software e hardware que são constituídos por módulos espaciais.

Segundo Câmara et al (2004), o termo SIG é aplicado para sistemas que realizam o tratamento computacional de dados geográficos e armazenam a geometria destes atributos que estão georreferenciados, ou seja, localizados na superfície terrestre e representados em uma projeção cartográfica. Já para Clarke (2001 apud in Oliveira, 2006), o SIG pode ser visto simplesmente como um conjunto de ferramentas que possibilitam a análise de dados espaciais. Ainda para Silva (1999 apud in Pavão, 2005), em uma visão mais complexa, os SIG's são aceitos como uma tecnologia que possui o ferramental necessário para realizar análises com dados espaciais e oferecem alternativas para 0 entendimento da ocupação e utilização do espaço.

Existem diversas discussões acerca das definições de SIG. No entanto, é importante ressaltar que além das definições, existe a questão da interdisciplinaridade no que diz respeito à utilização destes sistemas. O cientista político pode utilizar o SIG para analisar a exclusão social em grandes cidades brasileiras, conforme nos mostram diversas pesquisas desenvolvidas pelo Centro de Estudos da Metrópole ${ }^{1}$. Já o gestor ambiental pode utilizar o SIG para compreender remanescentes de um tipo de vegetação em reservas de proteção natural (RPPN), delimitar áreas de preservação permanente (APP) ou mesmo gerenciar pontos de coleta em áreas contaminadas; como é possível verificar nos termos de referências de estudos de impactos ambientais exigidos pela Secretaria do Verde de Meio Ambiente do Estado de São Paulo, ou pelo próprio órgão ambiental em nível federal, IBAMA. O geógrafo utiliza essa ferramenta para criar mapas temáticos diversos, interpretar fotos aéreas, imagens de satélite, bem como processá-las (fragilidade, mapas sínteses, etc) e posteriormente efetuar análises. Já um urbanista, pode utilizar a mesma ferramenta para elaborar um plano diretor de uma grande cidade brasileira, enquanto o publicitário ou

\footnotetext{
1 O centro de Estudos da metrópole é um centro de pesquisa que desenvolve estudos avançados sobre os temas relacionados aos processos de urbanização e metropolização de São Paulo e outras cidades brasileiras.http://www.centrodametropole.org.br/home.html
} 
administrador de empresas a utilizam para classificar áreas de influências de grandes lojas, conforme trabalham as empresas na área de geomarketing ${ }^{2}$. Esses são exemplos de vários profissionais que utilizam de maneira diversificada a mesma ferramenta. Contudo, apesar destas múltiplas aplicações, existe um problema de ordem conceitual encoberta pela interdisciplinaridade dos SIG's, que é a redução dos conceitos trabalhados em determinadas disciplinas a algoritmos e estruturas de informações utilizadas para armazenamento e tratamento de dados geográficos. Do ponto de vista da aplicação, portanto, utilizar um SIG implica não somente escolher as representações computacionais mais adequadas como também capturar "a semântica de seu domínio de aplicação". (CAMARA \& MONTEIRO, 2001:2)

De acordo com Câmara et al (2004) em uma visão abrangente, um SIG possui os seguintes componentes exemplificados na figura 2.

Figura 2: Arquitetura de um sistema de informações geográficas (SIG).

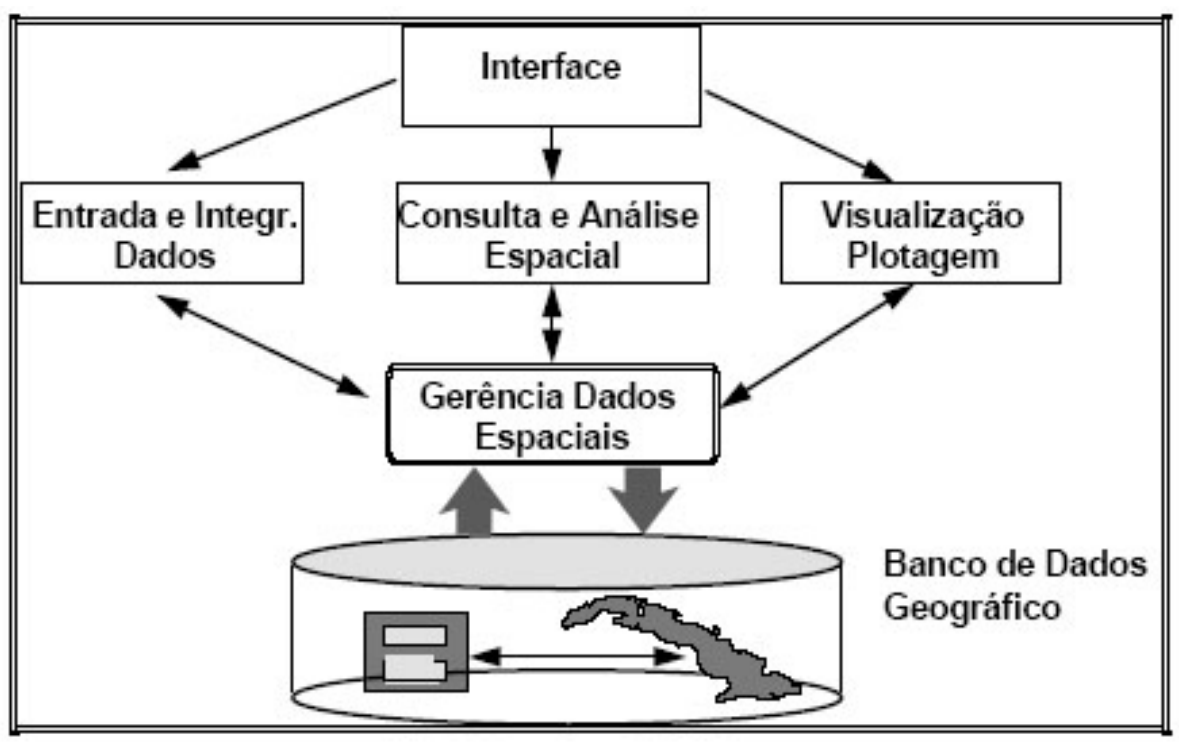

Fonte: Livro Análise Espacial e Geoprocessamento, Câmara et al., 2004 página 07.

Atualmente existem no mercado diversos SIG's com solução comercial como o Mapinfo, ArcGis (ESRI), Maptitude (CALIPER) e outros também de domínio público, como o SPRING, desenvolvido pelo Insituto de Pesquisas

2 Geomarketing é uma área do geoprocessamento que trabalha com questões relativas à espacialização de grandes lojas de varejo, bancos e etc. É um mercado que está em expansão e as empresas que trabalham nessa área geralmente são lideradas por Administradores ou publicitários. 
Espaciais - INPE. De um modo geral, todos possuem os componentes básicos apontados na figura acima, sendo que, as diferenças dizem respeito às funcionalidades e operações que são oferecidas ao usuário. Alguns SIG's possuem ferramentas para processamento de imagens, combinados com funções de análise de dados espaciais e MDT (modelagem digital de terreno) ou MNT (modelagem numérica de terreno), tais como o ArcGis (ESRI) e o SPRING (INPE) que é de domínio público ${ }^{3}$.

\subsubsection{SENSORIAMENTO REMOTO}

Sensoriamento Remoto, segundo Novo (2000) é a ciência que transforma dados de radiância de uma cena em informações sobre os objetos da mesma. Segundo o IBGE (2000), Sensoriamento Remoto é a utilização conjunta de sensores e equipamentos modernos para o processamento e transmissão de dados, visando o estudo do ambiente terrestre por meio do registro e da análise das interações entre a radiação eletromagnética e as substâncias que compõem o planeta, nas mais diversas manifestações.

O Sensoriamento remoto proporciona imagens, que são fonte de dados e estão cada vez mais sendo utilizadas para a elaboração de diferentes tipos de produtos cartográficos. Os mapas, um exemplo destes produtos, apresentam informações contidas nas imagens e estas, por sua vez, apresentam os dados brutos que somente se tornam informação após a sua interpretação e processamento.

Dependendo das características das imagens orbitais é possível empregálas em diversas áreas do conhecimento tais como: geologia, para se indicar o tipo de rocha, e assim poder inferir sobre a presença de jazidas, além de permitir a identificação de diferentes coberturas vegetais e assim um profissional da área propor um manejo adequado de uma RPPN, bem como dados diversos de uma área urbana, voltada ao planejamento da mesma.

De acordo com Kurkdjian (1993) as aplicações de sensoriamento remoto voltada ao planejamento urbano ocorrem em duas linhas:

- Voltada ao conhecimento e à ação sobre o sistema urbano, sua relação com o meio físico que o sustenta e com estudos regionais. Nessa linha, os produtos

${ }^{3}$ O donwload do SPRING pode ser efetuado no sítio: http://www.dpi.inpe.br/spring/. 
orbitais são de extrema importância para mapeamentos geológicos, geomorfológicos, expansão da mancha urbana, etc.

- Outra linha é aquela voltada para estudos intra-urbanos, os quais antigamente eram limitados pela resolução espacial dos produtos disponíveis. Atualmente, com os avanços tecnológicos na área de Sensoriamento Remoto, a disponibilidade dos produtos de alta resolução espacial obtidos pelos satélites Quickbrid (aproximadamente $0,6 \mathrm{~m}$ ) e Ikonos $(1 \mathrm{~m})$ estão revolucionando os estudos intra-urbanos e ampliando as possibilidades de aplicações desses dados para estudos relativos ao espaço urbano.

Brivio \& Zilioli (2001 apud in Oliveira, 2006) afirmam que apesar dos avanços do Sensoriamento Remoto, as áreas urbanas ainda apresentam um elevado número de dificuldades devido à complexidade da paisagem urbana e isso reflete uma heterogeneidade de materiais que interferem de sobremaneira nos resultados das classificações. As características das classificações (supervisionadas ou não) demandam a utilização da informação textura, combinada aos demais dados multiespectrais. Mas como reforça Morato (2004), com relação às áreas urbanizadas, as fotografias aéreas ou imagens de satélite de alta resolução mostram relativamente pouco a respeito dos fatos sociais, políticos e econômicos, ou seja, dependendo do estudo a ser realizado, a interpretação de imagens de satélites como forma de captação de dados, é uma opção importante para a coleta de dados, mas não pode ser considerada a única fonte. É importante ressaltar essa informação, de modo a destacar, portanto, a importância dos trabalhos de campo realizados no presente estudo, bem como a manipulação de dados secundários provenientes do Censo Demográfico 2000 (IBGE).

\subsubsection{IMAGENS DE SATÉLITE: IKONOS II}

O satélite Ikonos foi o primeiro a comercializar no mundo imagens com 1 metro de resolução espacial. Esse satélite foi lançado no dia 24 de fevereiro de 1999, da base aérea de Vandenberg, Califórina, Estados Unidos.As principais características das imagens produzidas pelo satélite Ikonos estão demonstradas na tabela 1: 
Tabela 1: Principais características das Imagens IKONOS II

\begin{tabular}{|c|c|}
\hline $\begin{array}{l}\text { Resolução } \\
\text { espacial }\end{array}$ & $\begin{array}{l}\text { Posição nominal de } 26^{\circ} \text { fora do Nadir: } \\
\text { Pancromática: } 1 \text { metro } \\
\text { Multiespectral: } 4 \text { metros }\end{array}$ \\
\hline $\begin{array}{l}\text { Bandas } \\
\text { Espectrais }\end{array}$ & Pancromática, Azul, Verde, Vermelha, Infravermelho próximo. \\
\hline $\begin{array}{l}\text { Acurácia } \\
\text { métrica }\end{array}$ & $\begin{array}{l}\text { Horizontal - } 12 \text { metros; Vertical - } 10 \text { metros; precisão relativa de pelo } \\
\text { menos } 90 \% \text { da cena. (Correção de Sistema sem pontos de controle } \\
\text { cartográfico (tipo map)) } \\
\text { Horizontal - } 2 \text { metros; Vertical - } 3 \text { metros; precisão relativa de pelo } \\
\text { menos } 90 \% \text { da cena. (Correção de Sistema sem pontos de controle } \\
\text { cartográfico (tipo precision plus)) }\end{array}$ \\
\hline $\begin{array}{l}\text { Tempo de } \\
\text { Revisita }\end{array}$ & $\begin{array}{l}\text { Aproximadamente } 3 \text { dias com } 1 \text { metro de resolução próximo à } 40^{\circ} \text { de } \\
\text { Latitude. }\end{array}$ \\
\hline Altitude & $681 \mathrm{Km}$ (423 milhas) \\
\hline
\end{tabular}

Fonte: Geoeye (2006).

Essas imagens estão sendo muito utilizadas em estudos intra-urbanos por uma série de fatores, especialmente devido à grande resolução espacial que permite a discriminação dos alvos com aumento dos detalhes e grande precisão cartográfica, que pode ser obtida através da ortorretificação. 
Mapa 1: Distrito de Cachoeirinha - São Paulo, Imagem Ikonos 2002

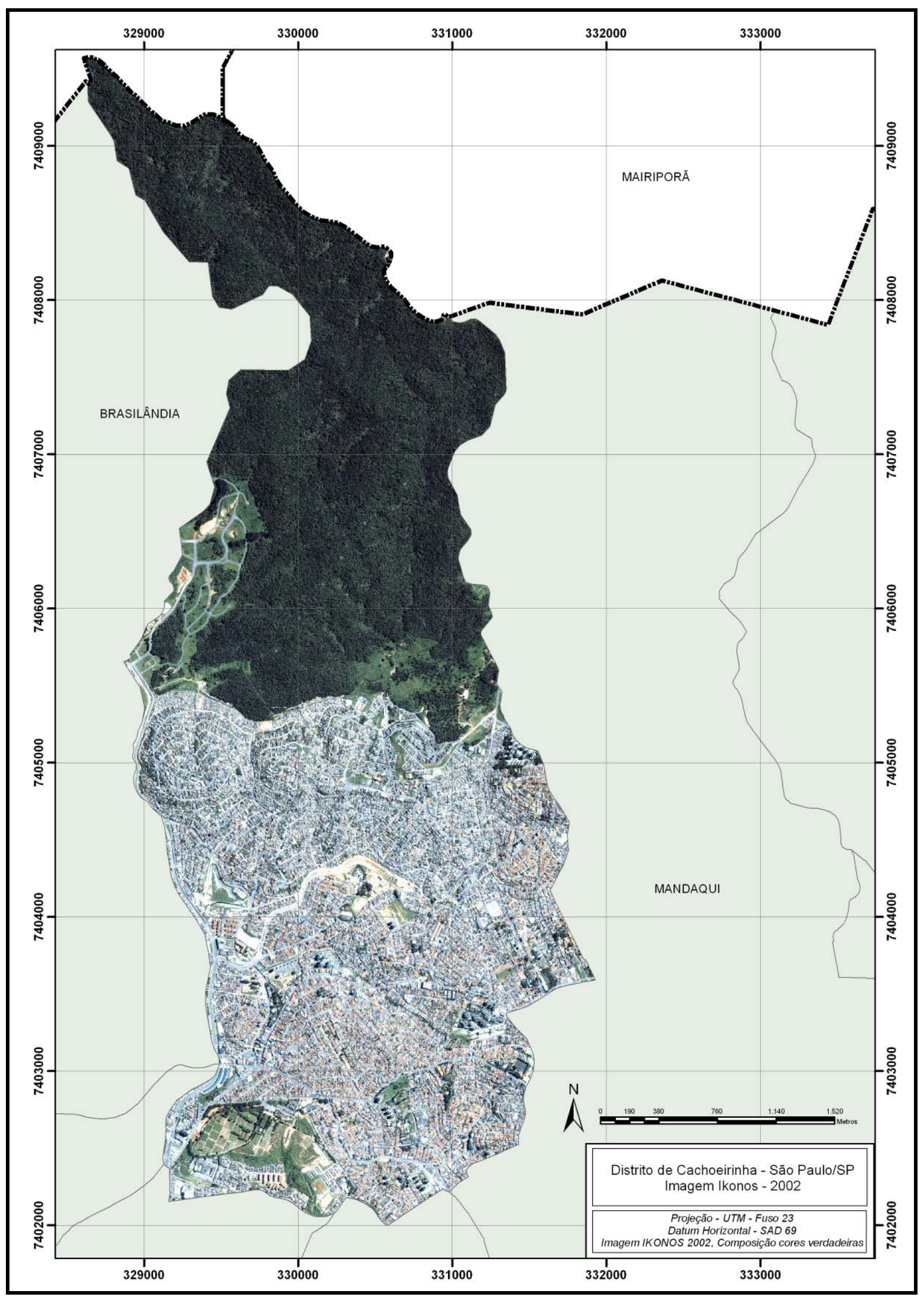

Fonte: Imagem Ikonos composição "cores verdadeiras", 2002. Elaborado pela autora, 2008. 


\subsubsection{SENSORIAMENTO REMOTO E ESTUDOS INTRA-URBANOS}

Segundo Villaça (1998), a expressão espaço intra-urbano surgiu da necessidade de diferenciar o espaço urbano de tal forma que este está comprometido com o componente urbano do espaço regional. Para o mesmo autor, esse espaço está estruturado fundamentalmente pelas condições de deslocamento do ser humano. Em seus estudos intra-urbanos Villaça ressalta a importância das localizações dos objetos urbanos e a necessidade de explicá-los, evidenciando deste modo, a segregação como um elemento central na definição da estrutura intra-urbana.

Com relação à segregação espacial, Villaça considera a dinâmica da moderna indústria do mercado imobiliário, causadora dessa segregação e a entende como um processo necessário para a dominação social do espaço, por parte das classes sociais mais abastadas, em torno das vantagens e desvantagens do espaço construído.

Para Marques (2005), a relação entre segregação e pobreza define uma desigualdade de especial relevância, que é a desigualdade de acesso. O grau da segregação residencial pode ser identificado por meio do grau de isolamento residencial entre diferentes grupos sociais.

Dentre diversos trabalhos realizados em áreas urbanas e com o uso de técnicas de fotointerpretação e sensoriamento remoto alguns estão em destaque a seguir:

Green, em 1958, citado em Foresti (1978) foi um dos primeiros pesquisadores a realizar estudos utilizando fotografias aéreas, visando à contagem de unidades habitacionais com um método para estimativas populacionais. Seu trabalho foi realizado na cidade de Birminghan no Alabama, onde foram utilizadas fotografias aéreas em branco e preto, na escala 1:7.500. Ele utilizou os seguintes critérios para a interpretação para identificar diferentes estruturas residenciais: forma do telhado, jardins e garagens para identificar diferentes estruturas residenciais. De acordo com Souza (2004), os bons resultados deste trabalho demonstraram a eficiência das fotografias aéreas para a caracterização de áreas em função da habitação.

Para Krauss et al (1974) os estudos de estimativas populacionais com a utilização de sensoriamento remoto podem ser realizados em três diferentes 
níveis: geral, semi-detalhados e detalhados. Eles propuseram e utilizaram o método semi-detalhado para estimar a população da Califórnia, relacionando medidas de áreas de três tipos de uso do solo, cada uma delas associadas às características populacionais. Neste trabalho foram utilizadas fotografias pancromáticas na escala 1:600.000 e infravermelho nas escalas de 1:120.000 e 1:60.000 respectivamente.

Manso e Barros (1975 apud in Kurkdjian 1986) elaboraram um modelo de qualidade urbana, baseado no método de investigação entre a relação das áreas residenciais homogêneas, detectadas pela fotointerpretação e a homogeneidade socioeconômica de seus habitantes. Foram utilizadas para a realização deste trabalho fotografias aéreas na escala 1:8.000. A cada zona homogênea foi atribuída uma densidade média populacional obtida pela fotointerpretação e por trabalhos de campo, visando o cálculo da população total da cidade.

Foresti (1978) desenvolveu um trabalho para a verificação e correlação entre áreas urbanas e população, obtidas em fotografias aéreas 1:25.000 e dados obtidos de imagens LANDSAT 1:500.000 e a correlação de ambos com os dados dos censos demográficos em 105 cidades do Estado de São Paulo.

Kurkdjian (1986) elaborou um método de setorização residencial urbana voltada para o planejamento urbano, com a utilização de fotografia aérea 1:10.000. Tal método foi exemplificado para a cidade de São José dos Campos/SP e vislumbrou o agrupamento de setores homogêneos e a identificação das características socioeconômicas da população residente.

Chanond (1987) explora em seu trabalho as mudanças no mercado de terras em áreas de franja urbana da cidade de Bangkok. Nesta pesquisa o autor explora a região metropolitana de Bangkok, localizada em uma das áreas mais férteis, com grande produção agrícola e que agora contém a maior população urbana da Tailândia. O autor examinou o uso do solo, os padrões de propriedade, e além disso, verificou se existiam terras disponíveis, se as mesmas eram suficientes para a expansão urbana e também utilizou dados sobre a especulação imobiliária no local, tentando deste modo descrever o processo de expansão da região de franja urbana e identificar os atores atuantes neste processo. Para a elaboração deste estudo foram utilizados dados de registros de terras, fotografias aéreas dos anos 1974 e 1984 respectivamente na escala 1:5.000, mapas 
cadastrais compilados pelo Departamento de terras, questionários e entrevistas com especialistas do mercado de terras.

Neste estudo Chanond (1987) elaborou as seguintes conclusões:

- As especulações sobre as terras à venda não são predominantes na área; os principais atores atuantes e responsáveis pelo parcelamento do solo na área são os corretores e os desenvolvedores (developers) que com sucesso loteiam a região;

- A população de baixa renda ainda está excluída do mercado de terras na franja urbana, porque a oferta para essa população também é pequena. A maior parte dessas terras já foi dividida de maneira que houve uma valorização promovida pela especulação imobiliária e, portanto, estas já adquiriram um preço alto para a população de baixa renda;

- O desenvolvimento da área de franja urbana consiste em divisões informais. A maioria das franjas urbanas está sendo desenvolvida em áreas de pouco acesso a serviços essenciais, o que resulta em uma forma de crescimento ineficiente, pois, haverá um custo mais elevado para se prover o local de infraestrutura. No futuro, o governo deverá exercer um desenvolvimento positivo provendo a área com serviços e infra-estrutura apropriados.

O autor conclui que deveria haver um monitoramento das terras urbanas pelas autoridades responsáveis pelas políticas habitacionais, visando uma maior acuidade dos dados com relação às mudanças do mercado imobiliário e consequentemente, que se possa o fornecimento contínuo de terras para suprir a demanda habitacional na área. Esse exemplo é importante para compreendermos como funciona a especulação imobiliária em uma franja urbana, ocupada sem planejamento, aonde os investimentos governamentais chegam posteriormente para suprir as necessidades da população que lá se instala. No caso acima, apesar da intervenção governamental, o autor conclui ainda que a população de baixa renda está excluída do processo devido à especulação que passa a valorizar mais a região.

Chen (2002) assim como Kurkdjian (1986), identificou zonas homogêneas, através da classificação textural, porém relacionou-as com a densidade residencial. Para este trabalho ele utilizou imagens LANDSAT com 30 metros de resolução espacial. 
Souza (2004) identificou os setores de textura homogênea da cidade de São José dos Campos/SP, visando à possibilidade de produzir informação demográfica atualizada, localizada, de forma rápida e econômica em períodos intercensitários. A autora buscou testar uma abordagem para estimar a população urbana da cidade, considerando a natureza do espaço residencial nas cidades brasileiras, sua estruturação, bem como as características socioeconômicas da população residente, através do uso de produtos orbitais de alta resolução. Para a realização deste trabalho foi utilizada imagem digital no modo colorido IKONOS com 1 metro de resolução espacial.

A autora citada concluiu que, através dos resultados obtidos, é possível evidenciar no espaço residencial das cidades um processo de exclusão concreto que se expressa através da segregação residencial. E também que, ao identificar no ambiente urbano áreas homogêneas, tanto com relação ao espaço construído, quanto com relação à população residente, abrem-se novas perspectivas para o estabelecimento de ações governamentais, tendo como unidade de planejamento, o setor homogêneo que permite inclusive a viabilização da participação de diferentes segmentos da sociedade nesse processo, articulados em torno de objetivos comuns.

Hutchinson et al (1993), elaboraram um estudo com aplicação de técnicas de fotografia aérea e SIG para o desenvolvimento de pesquisa com uma perspectiva histórica dos perigos ambientais em uma área de franja urbana. Os autores criaram um único banco de dados derivado das interpretações de fotografias aéreas, com a intenção de avaliar a relação entre o uso do solo e os problemas ambientais para a franja rural-urbana em Phoenix, Arizona, Estados Unidos.

Mapas de uso do solo e cobertura vegetal foram elaborados a partir da interpretação de fotografias aéreas de diferentes anos, construindo assim um histórico. Essa informação histórica foi utilizada para identificar as relações entre os perigos ambientais, as mudanças no uso do solo, com enfoque na transformação de área predominantemente agrícola em uso urbano.

A partir deste levantamento, algumas questões foram levantadas:

- Como foram remanejadas as áreas para destino do lixo durante a urbanização? 
- Que tipo de terra foi convertida em lixão e o que ocorreu com o uso anterior?

- Estas áreas eram apropriadas para tornarem-se lixão?

A área escolhida como amostra dentro da cidade de Phoenix tem vivido uma experiência contínua de urbanização. Para esse estudo foram empregados padrões de reconhecimento aéreo e técnicas fotogramétricas em conjunto com um material de apoio, como mapas topográficos, relatórios e fotografias.

Os resultados obtidos foram:

- Houve mudança significativa na área de estudo durante os 32 anos abordados na pesquisa;

- Em 1985 a área de estudo tornou-se mais residencial e industrial com área de agricultura irrigada decrescente em 28\%, enquanto residências cresceram $31 \%$ e indústria e comércio cresceram 19\%. Áreas públicas e urbanas ainda não desenvolvidas cresceram $13 \%$.

- Foi elaborado um histórico do uso do solo e da área de lixões. Essa análise demonstrou que a maioria das terras disponíveis e dos depósitos de lixo na área de estudo foi localizada ao longo do Salt River.

As conclusões dos estudos evidenciaram que a interpretação de fotografias aéreas é de grande valor para localizar áreas de depósitos de lixos em conjunto com as mudanças de uso dos padrões urbanos e a densidade populacional. Os resultados das análises dos autores revelaram que o crescimento da industrialização e da população urbana se deu de forma acelerada, gerando mais dejetos sólidos e líquidos na área de Phoenix. Neste contexto, o autor avalia que foi importante estudar a região da franja rural-urbana de Phoenix para exemplificar como o histórico do uso do solo pôde ser agregado aos locais dos depósitos de lixo; e a utilização do SIG, viabilizou a caracterização da área de risco ambiental. A análise espacial também revelou que as áreas destinadas aos lixões estavam em locais inapropriados e com solos também inadequados e que essa combinação poderia trazer riscos para a população. 
"Uma das características mais marcantes do nosso tempo está na dimensão que as dinâmicas e fenômenos naturais assumiram, não apenas no dia-a-dia de cada um, mas também na agenda política e econômica mundial." (Hogan et al., 2005:32)

Para Hogan \& Marandola Júnior (2006) é neste cenário que surge a noção de vulnerabilidade, num primeiro momento, mas, principalmente após a $2^{\mathrm{a}} \mathrm{Grande}$ Guerra, quando os fenômenos naturais que chamavam atenção do cientista sob ponto de vista das implicações sociais eram catástrofes ou desastres naturais tais como, terremotos, enchentes, deslizamentos de encostas, nevascas, tornados que foram estudados nas mais diversas formas. Hogan et al. (2006) afirmam que os geógrafos, tal como os exemplos citados, estudaram os natural hazards, os perigos naturais provenientes de um determinado risco de ocorrência, que produziam de acordo com a intensidade, os desastres. Os interesses estavam não apenas no fenômeno em si, mas sim em como os homens se ajustavam e procuravam respostas a esses eventos.

Após décadas estes estudos tiveram seus enfoques modificados, visando compreender a complexa rede de relações "humano-físico-sociais que estão na base genética dos desastres (...)”(Hogan \& Marandola Júnior, 2006:33), sendo incorporados, portanto, fenômenos de origem tecnológica que afetam o meio ambiente e conseqüentemente a sociedade, tais como, contaminações, intoxicações, desastres químicos provenientes de indústrias além de fenômenos sociais como a violência, pobreza e a fome.

Desde então, catástrofes que chamaram a atenção no primeiro momento somente dos cientistas, chocam agora a opinião pública e colocam em evidência a problemática ambiental, demonstrando a sua indissociabilidade com a social.

Moura (2003) apresenta em sua Tese de Doutorado um sistema apoiado no Geoprocessamento voltado à análise espacial para o planejamento urbano. Para a composição de exemplos e verificação das propostas metodológicas a autora destaca a cidade de Ouro Preto, Minas Gerais, Patrimônio da Humanidade.

A autora utilizou a experiência aplicada de "árvores de decisões" em projetos para diagnósticos de áreas ambientais, em programa de urbanização de favelas em Belo Horizonte, conforme mostra a figura 3 : 
Figura 3: Árvore de decisões

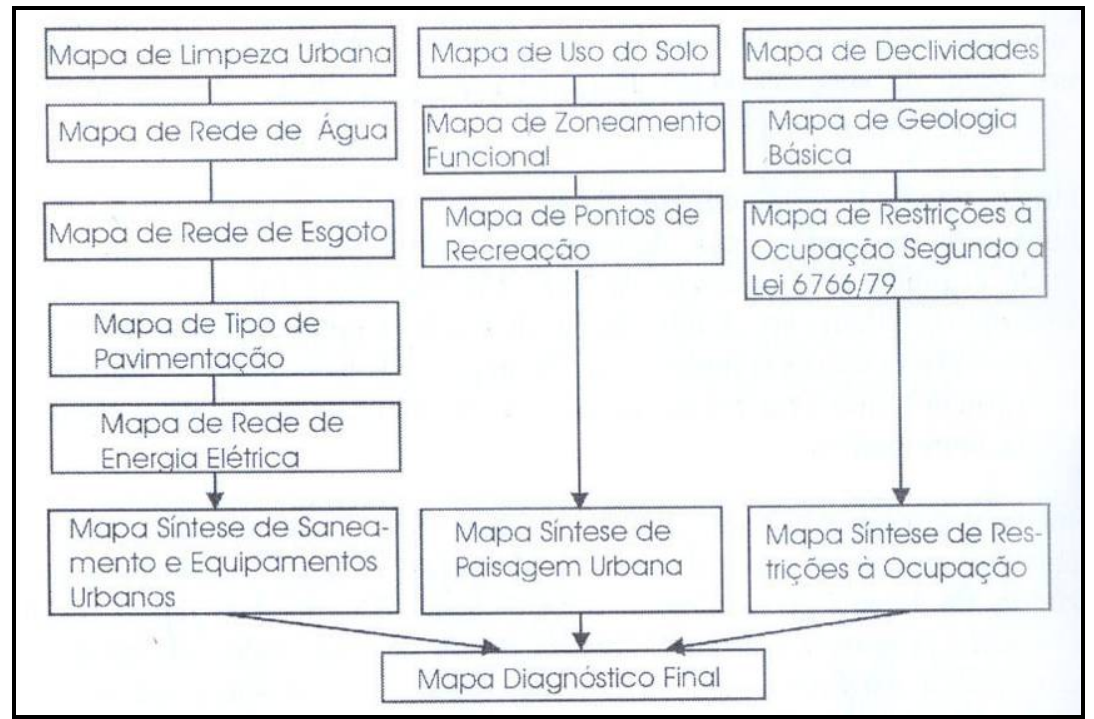

Fonte: Árvore de decisões extraída do livro Geoprocessamento na Gestão e Planejamento Urbano. Belo Horizonte: Editora da autora, 2003.

Moura (2003) enfatiza que no decorrer da pesquisa vários tipos de zoneamentos foram construídos, segundo diferentes tipos de análise, mas que fora destacado no final o mapa que classificou a cidade segundo a qualidade de vida urbana. No corpo do trabalho a autora descreve as metodologias envolvidas na moldagem a árvore de decisões até a construção da síntese final do mapa de Qualidade de vida urbana. É interessante notar que para se atingir tal meta, várias outras sínteses foram realizadas.

Dentro da linha que envolve o sensoriamento remoto em estudos voltados ao espaço intra-urbano, com os mais diversos objetivos, foi possível perceber, que os três níveis elaborados por Krauss (1974), antes somente voltados às estimativas populacionais, foram reelaborados e podem ser identificados nas pesquisas descritas acima quanto aos métodos e procedimentos utilizados. Outra questão que pôde ser verificada diz respeito às escalas: quanto maior a escala, mais detalhado será o trabalho. Quanto maior a resolução espacial das imagens de satélite, maior também será o nível de detalhamento da pesquisa e dos resultados obtidos. A qualidade dos dados, portanto, é diretamente proporcional aos níveis/métodos que são propostos nas pesquisas desta área. 


\subsection{ESTUDOS URBANOS E A CIDADE DE SÃO PAULO}

As cidades são objetos de estudo de vários campos científicos, Arquitetura e Urbanismo, Sociologia, Antropologia, Geografia, etc. De modo geral, a Geografia Urbana preocupa-se com questões relativas às áreas urbanas e seus processos de produção do espaço.

A cidade de São Paulo possui abundantes estudos sobre seu espaço urbano, permeando todas as áreas citadas acima, com as mais diversas abordagens.

Para os geógrafos estudiosos do espaço urbano, tal como Carlos (1994), a construção de um arcabouço teórico que ultrapassasse a noção de espaço como palco da vida, fez-se necessário para compreender o processo de produção e reprodução do espaço urbano. Dessa forma o enfoque da pesquisa dessa autora, volta-se para discussões não mais da paisagem urbana como um elemento estático. Mas sim, do ciclo do capital como elemento do processo de produção do espaço, dos movimentos sociais urbanos e seu papel no processo de reprodução espacial, da problematização da teoria do valor e por fim, do papel do Estado no processo de produção do urbano como incentivador das condições gerais de reprodução do capital e também, contraditoriamente, gerenciador de crises sociais. Fica explícito o paradigma marxista predominante no estudo urbano e regional, e presentes principalmente na produção dos anos 70 e 80 , no campo da geografia e da sociologia.

$\mathrm{Na}$ introdução da obra Geografias de São Paulo (2004) os organizadores deixam claro a dificuldade de comparação desta obra, com a organizada por Aroldo de Azevedo, em razão da comemoração do quarto centenário da cidade de São Paulo. A obra A Cidade de São Paulo, citada no presente texto, fez parte de um projeto pessoal de seu coordenador, enquanto que Geografias de São Paulo baseou-se em um projeto distinto, impossibilitando comparações. Outro aspecto importante é a maneira de se compreender a realidade e as maneiras pelas quais são feitas as análises geográficas que em A cidade de São Paulo, demonstram ser específicas de uma época e já superadas pela geografia urbana atual.

A obra A cidade de São Paulo, segundo seu coordenador, foi um projeto para ser completo, um estudo de geografia urbano bem detalhado. Geografias de 
São Paulo, de acordo com seus idealizadores, foi um convite aos professores do Departamento de Geografia da Universidade de São Paulo, a escreverem sobre um aspecto da cidade de São Paulo, a partir de suas pesquisas individuais. Essa obra apresenta diversas perspectivas de se estudar a metrópole, com diferentes abordagens teóricas e metodológicas e temporais.

Frugoli Júnior (2000) aborda questões relativas à cidade moderna, que segundo o autor, passa a ser o espaço de constante interação entre grupos sociais, onde a diversidade e os conflitos sociais ganham maior visibilidade e dramaticidade. No caso de estudos urbanos e de caráter sociológico sobre a cidade de São Paulo nos anos 70 e 80, o enfoque se deu em processos sociais gerados na periferia. O centro tradicional da cidade de São Paulo, símbolo da elite paulistana no início do século XIX, passou por um período de crescimento e valorização e foi ao longo dos anos sendo degradado e abandonado, dando lugar às classes populares.

A clássica e complexa relação centro-periferia transforma-se atualmente com a proliferação de condomínios fechados principalmente em áreas periféricas da mancha urbana da região metropolitana de São Paulo. As classes sociais de melhor poder aquisitivo, iniciam um processo de entrincheiramento, representado por sofisticados sistemas de segurança e pela vida intramuros. É a ocupação do centro tradicional pelas classes populares, a segregação das classes média e alta, e o conseqüentemente desdobramento da centralidade em São Paulo.

Marques (2005), ao escrever sobre a segregação espacial destaca a importância da localização das periferias e a infra-estrutura próxima a cada uma delas e indica que esse fator é de fundamental importância para uma caracterização no que diz respeito à qualidade de vida da população destes locais.

Certo está que estudos sobre a cidade de São Paulo e suas diversas abordagens fazem parte da complexidade inerente à metrópole. Sua análise revela um processo que contempla a prática socioespacial, na qual sua reprodução ganha um sentido prático no plano do lugar, analisado a partir dos bairros e distritos, que compõe a metrópole. 


\subsubsection{QUALIDADE DE VIDA}

O tema qualidade de vida envolve questões multidisciplinares apresentadas com contornos diferenciados, de acordo com a relevância do momento histórico, das condições sociais, bem como da ideologia dominante a partir dos objetivos propostos.

Morato (2004) ressalta que diversas áreas do conhecimento, tais como a Estatística, a Economia, as Ciências Sociais, o Urbanismo, a Geografia e a Saúde Pública, têm se preocupado com esta temática. Cada ciência entende a qualidade de vida segundo suas metodologias e instrumentos e análise, o que implica também na multiplicidade de significados associados ao conceito de qualidade de vida, ou melhor, aos vários conceitos de qualidade de vida.

Para mensurar a qualidade de vida Mccall (1973 apud in Morato, 2004) afirma que o melhor caminho para a abordagem é medir o alcance das necessidades das pessoas, ou seja, são as condições necessárias a serem satisfeitas, sem as quais nenhum membro da raça humana pode ser feliz.

Segundo Napoleão (2005), o conceito de qualidade de vida envolve diversos aspectos, tais como, a dimensão demográfica, a percepção dos indivíduos, os indicadores sociais entre outros.

De acordo com Garcia (1999 apud in Napoleão, 2005), estudiosa da qualidade de vida e da sustentabilidade urbana, o termo qualidade de vida corresponde ao entorno natural que proporciona serviços biológicos, classificados pela autora como o acesso a ar puro, água limpa, solos disponíveis, assim como serviços estéticos que seriam belas paisagens e serviços científicos, tal como o conhecimento. A autora também ressalta a importância da diferenciação de conceitos, como por exemplo, nível de vida, relacionado para Garcia, ao o nível individual de consumo e condição de vida, que são as relações do homem com a sua situação social, acesso à saúde, educação, alimentação, tempo livre etc.

Mas em se tratando das grandes cidades brasileiras, São Paulo apresenta indicadores melhores quando comparada a outras grandes metrópoles do mundo, tal como Mumbai, onde se estimava que em 1991, 45\% da população de sua população viviam em assentamentos ilegais e, no ano do último censo realizado na cidade em 2001, metade da população vivia em favelas, cerca de 5,9 milhões de pessoas. Na Cidade do México no ano 2000, 59\% de sua população residia 
em favelas ou em cortiços enquanto que em São Paulo no mesmo ano eram 20\% de sua população vivendo em favelas (Ferreira, 2000). Outro aspecto importante ressaltado pelo mesmo autor é o fato de que enquanto a taxa média de crescimento anual das cidades brasileiras em 2000 era de 1,93\%, o da periferia de São Paulo chegava a 4,3\% ao ano. Em Deli, na Índia, enquanto a região urbanizada crescia 3,8\% ao ano, no período de 1981 a 1991, as zonas rurais próximas à mancha metropolitana urbanizavam-se ao ritmo de 9,6\% ao ano. Apesar dos números apresentados, a pobreza ainda causa perplexidade na capital paulista, já que há muito mais pobres do que ricos e ainda que alguns dos serviços essenciais elencados anteriormente (transporte, acesso à saúde, educação...) já tenham sido estendidos às bordas urbanas, logo novas áreas são ocupadas por mais ondas migratórias, formando novas favelas e novos loteamentos irregulares.

O termo crescimento desordenado é comumente utilizado para a São Paulo que pouco oferece para a qualidade de vida de seus habitantes. Entretanto, apesar do termo ser relacionado à falta de planejamento, são comuns estudos que utilizam o "desordenado", desconsiderando a ordem perversa e atuante da especulação imobiliária. A política urbana, de acordo com Rolnik (2000), foi e é intensamente utilizada como instrumento de exclusão e perpetuação de privilégios e desigualdades. A regulação urbanística, que faz parte das políticas urbanas, vem também reforçando a dualidade imposta entre pobres e ricos, a primeira marcada pela irregularidade e a segunda pela renovação das oportunidades de reinvestimentos do mercado imobiliário e a proteção da qualidade de vida dos mesmos.

Penna (2002) aborda em seu texto "Urbanização, Cidade e Meio Ambiente" a questão do aparente crescimento desordenado:

"A desordem na produção do espaço oculta a ordem da oposição entre a produção pública e a produção privada da cidade: uma se define em relação à outra e contra a outra. A análise imediata dos processos desordenados é apresentada como caos. Na realidade, apenas não reconhece na paisagem urbana as próprias condições de sua existência. Essa lógica põe em evidência que a realidade urbana desapareceu mutilada pela lógica da mercadoria e da especulação imobiliária. Esta ordem política estratégica fica 
ocultada pelas análises da cidade desordenada, da periferia desorganizada e segregadora. É apenas diante da análise simplificada da realidade que a contradição é desordem, para tornar necessária a restauração da ordem, da coerência e da harmonia na realidade caótica por intermédio da ação burocrática governamental. Nesse sentido, a análise exclusiva da paisagem aparente da cidade é uma arbitrariedade, reduzindo uma totalidade complexa e em constante transformação a um de seus momentos." (PENNA, 2002:5)

A elucidação do desordenamento da cidade por Penna nos faz refletir o quão difícil é estudar apenas um momento da periferia ou o retrato da segregação.

Jordan (1985) trabalha com a idéia de que os assentamentos urbanos não podem ser tratados de forma isolada dos fatores que influenciam na qualidade de vida e na "consecução" dos objetivos de desenvolvimento. Para o autor, modificar a visão do planejamento e da gestão territorial vigente é necessário para:

“(..) impulsionar um processo de reconversão conceitual no qual a preocupação com a qualidade de vida de toda a população apareça ligada às condições de moradia, saneamento básico, prestação de serviços socais e de infra-estrutura, equipamento comunitário, segurança que são componentes essenciais do meio ambiente construído". (Jordan in América Latina: Crise nas Metrópoles (SEMPLA), 1985:13)

No ano 2000, o Instituto Florestan Fernandes e Jorge Wilhein Consultores Associados, por iniciativa da prefeitura do município de São Paulo, no início da gestão de Marta Suplicy, elaboraram um documento intitulado de "Intervenções na Paisagem Urbana de São Paulo". Este texto encaminha propostas e idéias para uma intervenção que vise melhorar a paisagem urbana e a partir desta, desencadear uma melhora na qualidade de vida de seus habitantes. De acordo com o estudo, os autores pontuam que a qualidade da paisagem urbana é elemento fundamental na qualidade de vida das pessoas e ressaltam a importância da satisfação das necessidades básicas, tais como: alimentação de subsistência, habitação, saúde física ou mental, segurança básica propiciada pelo fruto de seu trabalho, renda mínima para subsistência, instrução que lhe possibilite participar da vida societária. Após esta etapa é que poderemos pensar 
em termos de demanda por qualidade de vida, sendo que segundo o texto, os fatores que classificam a qualidade de vida podem ser agrupados em duas categorias: físicos/fisiológicos e sócio/psicológicos. Conforme demonstrado no quadro a seguir:

Figura 4: Intervenções na Paisagem Urbana de São Paulo

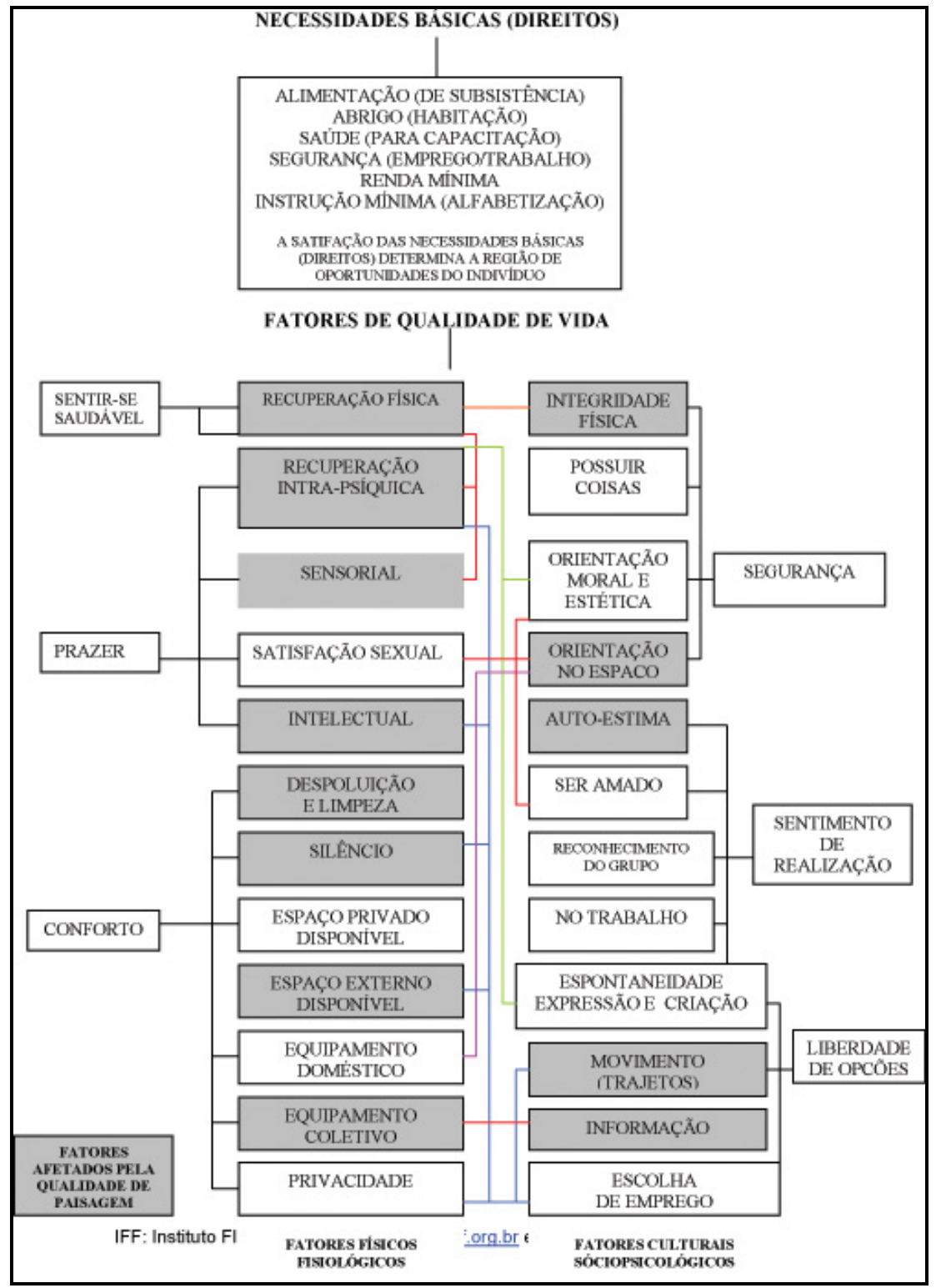

Fonte: Quadro extraído do texto "Intervenções na Paisagem Urbana de São Paulo", Instituto Florestan Fernandes e Jorge Wilheim Associados, Maio de 2000.

Oliveira (2006) aborda em sua pesquisa a qualidade ambiental como componente fundamental da qualidade de vida. Nesse sentido, a avaliação da autora baseou-se em unidades da paisagem, segundo características 
homogêneas, na qualidade dos indicadores de saúde e no saneamento básico da população residente no interior da bacia hidrográfica do rio Itaquera.

Para Ribeiro \& Vargas (apud in Oliveira, 2006), o conceito de qualidade ambiental urbana está diretamente ligado aos conceitos de ecossistema urbano e o de qualidade de vida. Segundo essas autoras, os principais aspectos que devem ser considerados na avaliação da qualidade ambiental urbana são: espaciais, biológicos, sociais e econômicos.

Segundo Nucci (2001), as características que interferem nas necessidades humanas não mudam ao longo da vida: ar fresco, água potável, certa quantidade de alimento por dia, espaço para dormir e para interagir. Ar, água, espaço, energia, abrigo e disposição de resíduos, são consideradas as novas raridades em torno das quais se desenvolve uma intensa luta (Lefevbre, 1969 apud in Nucci, 2001), e fazem parte da necessidade biológica do ecossistema urbano. Essas necessidades influenciam sobremaneira na qualidade do ambiente $\mathrm{e}$ podem funcionar como fatores limitantes à urbanização, podendo influenciar diretamente na qualidade de vida da população. Este autor desenvolveu uma metodologia qualitativa de avaliação da qualidade ambiental para o distrito de Santa Cecília município de São Paulo, baseado na linha teórica da ecologia da paisagem. Nucci (2001) considerou sete atributos negativos: enchentes, desertos florísticos, déficit de espaços livres públicos, densidade populacional acima de $400 \mathrm{hab} / \mathrm{ha}$, verticalidade acima de seis pavimentos (exceto áreas mistas), uso do solo distintos e uso residencial ou praças. As áreas que apresentam uma boa qualidade ambiental são aquelas que apresentam somente um ou nenhum atributo negativo. As piores áreas ambientais apresentam entre seis e sete atributos negativos.

Para Nahas (2001), com o aprofundamento da consciência ecológica a partir da década de 1970 provocada pelo agravamento da degradação ambiental urbana e pelo agravamento dos problemas ambientais globais, o conceito de qualidade de vida foi vinculado ao conceito de qualidade ambiental. Nessa década, o debate acerca da qualidade ambiental assume lugar de destaque no debate político internacional e sua incorporação trouxe uma série de outras implicações com relação ao dimensionamento, e a própria concepção de qualidade de vida vinculada à noção do desenvolvimento sustentável. Deste modo, a partir da compreensão de que a sustentabilidade do desenvolvimento 
humano é fruto da interação de processos socioeconômicos e da dinâmica ambiental, ao longo dos anos, foram sendo produzidos subsídios teóricos e metodológicos voltados para men suração de variáveis ecológicas e de monitoramento ambiental, que culminaram na formulação de metodologias; visando avaliar a população acerca da qualidade do seu meio ambiente, assim como ocorreu com os indicadores sociais.

"Como se observa até aqui, no campo conceitual, a mescla entre os dois conceitos (qualidade de vida e qualidade ambiental) é de tal ordem, que muitas vezes torna-se difícil estabelecer se a qualidade de vida é um dos aspectos da qualidade ambiental, ou se a qualidade ambiental é um componente do conceito de qualidade de vida. Na prática, a abrangência de cada um dos conceitos se explicita ao serem estabelecidos e aplicados métodos para sua mensuração, que acabam, assim, contribuindo para a formação do próprio conceito." (Nahas, 2001:4)

Andrews e Withey (1976) estruturaram componentes do bem-estar como elementos fundamentais da qualidade de vida, investigando diferentes percepções do bem-estar e desenvolvendo esforços para medi-lo. Os autores sugeriram que estes métodos se traduzissem em indicadores sociais e que nesses fossem considerados os diversos aspectos do meio em que vivem os indivíduos tais como habitação, poluição, criminalidade, etc.

A qualidade de vida é um conceito muito complexo cujas definições perpassam as esferas econômica, social, política, psicológica, espacial nas quais cada sociedade está inserida. (Napoleão, 2005)

Não existe uma unanimidade sobre compor os critérios de definição da qualidade de vida em si, nem tampouco indicadores necessários para tal conceituação entretanto, há um consenso entre os pesquisadores de que se faz necessária alguma mensuração voltada para diversas áreas, tais como as de planejamento, sejam esses ambientais, urbanos ou ambiental-urbanos.

Napoleão (2005) destaca do ponto de vista metodológico, três momentos do desenvolvimento do conceito de qualidade de vida, destacados a seguir:

- 1960: a qualidade de vida passa a ser reconhecida como importante indicador. Corresponde à fase dos estudos de caráter quantitativo baseados em 
indicadores objetivos, elaborados utilizando dados e fontes provenientes das estatísticas oficiais. Essa fase perdurou até meados dos anos 1970.

- 1980: estudos qualitativos, indicadores subjetivos, percepção do homem. Nesta linha de pensamento encontram-se as idéias de Knox (1975), quel afirma que existem aspectos da qualidade de vida que não podem ser medidos quantitativamente.

- Pós década de 1980: qualidade de vida está relacionada à combinação de dois critérios, o objetivo e o subjetivo. A dimensão espacial também foi incorporada como um elemento fundamental na definição da qualidade de vida.

Nussbaum e Sen (1998) dividem as metodologias de qualidade de vida em três grupos: as que dão ênfase aos bens, às utilidades e à satisfação das necessidades básicas. Os economicistas focalizam na primeira, isto é, na idéia de que desenvolvimento não ocorre sem prosperidade material. Já a visão utilitarista enfatiza excessivamente os estados mentais excessivamente e negligencia outros aspectos do bem-estar. O enfoque das necessidades básicas estabelece incentivos para se atingir o pleno desenvolvimento físico, mental e social, mas deixa imprecisões a respeito de quais são essas necessidades e de como elas podem variar individualmente. (Morato, 2004)

Pode-se definir qualidade de vida como o bem-estar de um indivíduo ou de um grupo determinado, pela satisfação das necessidades dos seres humanos e em se tratando de uma abordagem ecológica, o grupo deve ser privilegiado na análise.

A avaliação da qualidade de vida, portanto, pode ser efetuada tanto em termos quantitativos e qualitativos, desde que se leve em consideração a organização espacial que possibilite uma classificação e conseqüentemente, ofereça subsídios para a implantação de políticas públicas visando melhorar efetivamente a vida da população. 


\subsubsection{INDICADORES SOCIAIS}

Segundo Januzzi (2002) um indicador social é uma medida quantitativa dotada de importância social significativa, utilizada para operacionalizar e/ou quantificar um conceito social abstrato, com interesses voltados às pesquisas acadêmicas ou para a formulação de políticas públicas. $O$ autor ainda complementa que o indicador social é um recurso metodológico que informa algo sobre um aspecto da realidade social ou sobre as transformações que nela estão sendo processadas.

Para a pesquisa acadêmica, o indicador social se apresenta como o elo entre os modelos explicativos da Teoria Social e a evidência empírica dos fenômenos sociais observados. O indicador social é um instrumento operacional para o monitoramento da realidade social para fins de formulação de políticas públicas. (Januzzi, 2002)

Nos estudos sociais, o desenvolvimento de indicadores vinculados ao meio urbano se intensifica a partir de 1990, após a formulação do índice de Desenvolvimento Humano (IDH) calculado para mais de cem países a partir de indicadores de renda da população, de saúde e de educação. (PNUD, 1998)

Com relação à inserção do desenvolvimento no conceito de qualidade de vida, esta perspectiva tem sido analisada historicamente através de diversas abordagens relacionadas às necessidades humanas e ao meio ambiente de maneira indissociável.

As Organizações das Nações Unidas (ONU) adota desde os anos 1990 o paradigma do desenvolvimento humano. A reorientação do foco do desenvolvimento para as pessoas reconsidera as expectativas das mesmas com relação à vida e todas as esferas que a envolve.

O conceito de desenvolvimento humano de acordo com o Programa das Nações Unidas para o Desenvolvimento, PNUD (1998) é à base do Índice de Desenvolvimento Humano (IDH). Esse índice foi construído partindo-se do pressuposto de que para aferir o avanço de uma população não se deve considerar apenas a dimensão econômica, mas também outras características sociais, culturais e políticas que influenciam a qualidade da vida humana. $\mathrm{O}$ PNUD sustenta que o conceito de "desenvolvimento humano" se diferencia de outros enfoques previamente existentes. Primeiramente, não compartilha com as 
teorias do capital humano nas quais se considera que as pessoas sejam meio de produção e não objetivos finais. Em segundo lugar, também se diferencia dos enfoques de bem-estar que consideram as pessoas como beneficiárias do desenvolvimento e não como participantes. (GUIMARÃES \& JANNUZZI, 2004:4)

O IDH foi elaborado pelo economista paquistanês Mahbub ul Haq com a colaboração do economista indiano Amartya Sen, ganhador do Prêmio Nobel de Economia de 1998. Seu objetivo foi contrapor o indicador PIB (Produto Interno Bruto), que considera apenas a dimensão econômica do desenvolvimento. A primeira publicação do índice ocorreu em 1990 e aos poucos se tornou referência mundial. O IDH é uma medida sintética do desenvolvimento humano e não visa abranger todos os aspectos de desenvolvimento, não representa a "felicidade" das pessoas, nem indica "o melhor lugar no mundo para se viver". Esse índice considera os valores do PIB corrigidos pelo poder de compra da moeda de cada país do PIB e também pelas componentes longevidade e educação. A componente longevidade é medida pela expectativa de vida ao nascer; já a educação é constituída pelo índice de analfabetismo e a taxa de matrícula em todos os níveis de ensino. A variável renda é composta pelo PIB per capita, em dólar PCC (paridade do poder de compra, que elimina as diferenças de custo de vida entre os países). As três dimensões, obtidas por média aritmética, têm a mesma importância no índice, que varia de zero a um, possibilitando a hierarquização dos países avaliados. (PNUD, 1998)

Com relação às experiências de mensuração da qualidade de vida no Brasil e seus desdobramentos, podemos destacar as seguintes.

Para se trabalhar com o Índice de Desenvolvimento Humano em nível municipal, foi elaborada uma adaptação do IDH, produzida pela Fundação João Pinheiro e seus parceiros, é o IDH-M. Esse índice visa representar e medir a complexidade das condições de vida dos municípios e proporcionar a comparação entre diversas cidades brasileiras e pode ser consultado no Atlas do Desenvolvimento Humano no Brasil. (PNUD, 1998)

Nahas (2001) faz uma síntese da experiência da elaboração de indicadores sociais como instrumentos balizadores da gestão municipal da qualidade de vida urbana da cidade de Belo Horizonte. A autora ressalta a importância da construção de indicadores e os classifica como instrumentos de gestão urbana. 
Na primeira versão, o Índice de Qualidade de Vida Urbana (IQVU) da cidade de Belo Horizonte (MG), calculado com dados do ano de 1994, era compostas por 75 indicadores relacionados às mais diversas esferas de serviços intra-urbanos: Abastecimento, Assistência Social, Cultura, Educação, Esportes, Habitação, Meio Ambiente, Segurança e Serviços Urbanos, distribuídos pela Unidade de Planejamento (UP). Esse índice (IQVU) foi elaborado para subsidiar uma distribuição equânime dos recursos municipais. A partir do ano 2000 o IQVU passou a ser o critério de distribuição de verbas destinadas ao orçamento participativo de Belo Horizonte e teve uma primeira atualização de dados em 1996. (Nahas, 2001)

Com a experiência e os recursos técnicos apreendidos no processo de construção do IQVU, foi possível o desdobramento para outro índice: o Índice de Vulnerabilidade Social (IVS) inserido no contexto do "Mapa da Exclusão Social de Belo Horizonte".

As metodologias geradas e o processo de elaboração destes índices estão inseridos em um contexto de discussões teórico-metodológicas que foram intensificadas a partir da década de 1970; e estão relacionadas às necessidades de formulação de indicadores urbanos e ambientais para o monitoramento das condições de vida das populações urbanas, e também para serem utilizados como instrumento de subsídio às políticas públicas no processo de tomada de decisões.

O IQVU é um índice urbanístico, de acordo com o seu modelo formal de cálculo. É uma medida de acessibilidade ao serviço, estabelecida com base no tempo de deslocamento entre as unidades espaciais que, além disto, consideram informações espacializadas de diversas maneiras, privilegiando dados sobre a oferta de equipamentos e afins, atribuindo pesos maiores para as variáveis Habitação e Infra-estrutura Urbana no seu cálculo. (Nahas, 2001)

Através do IQVU é possível identificar na cidade as regiões onde a oferta e o acesso aos serviços são menores e que, portanto, devem ser priorizadas na distribuição dos recursos; e quais os serviços devem ser priorizados em determinadas regiões para elevar o IQVU do lugar e deste modo, melhorar a vida da população.

Em Curitiba desde 1987 o Instituto de Pesquisa de Planejamento Urbano IPPUC, desenvolve o Índice sintético de satisfação da qualidade de vida (ISSQV). 
Esse índice é composto por indicadores distribuídos nos 75 bairros da cidade e tem como objetivo demonstrar o acesso da população à educação, saúde, transporte e educação. Deste modo, criou-se um ranking onde se podem observar quais bairros estão melhores e quais necessitam de investimentos em algumas dessas áreas. (Nahas, 2001)

Sposati (1996) elaborou o Mapa da Exclusão/Inclusão Social da cidade de São Paulo e o define como uma metodologia que faz uso de linguagens quantitativas, qualitativas e de geoprocessamento para produzir dois índices territoriais que hierarquizam regiões de uma cidade de acordo com o grau de exclusão/inclusão social. Esses índices são: Î́ndice de Exclusão/Inclusão Social (lex) e o Índice de Discrepância (Idi).

O lex dimensiona o quanto a população se encontra excluída com relação às seguintes variáveis temáticas: autonomia, desenvolvimento humano, qualidade de vida e equidade. A autonomia é definida pela autora:

“(...) como a capacidade e a possibilidade do cidadão em suprir suas necessidades vitais, especiais, culturais, políticas e sociais, sob as condições de respeito às idéias individuais e coletivas, supondo uma relação com o mercado, onde parte das necessidades deve ser adquirida, e com o Estado, responsável por assegurar outra parte das necessidades; a possibilidade de exercício de sua liberdade, tendo reconhecida a sua dignidade, e a possibilidade de representar pública e partidariamente os seus interesses sem ser obstaculizado por ações de violação dos direitos humanos e políticos ou pelo cerceamento à sua expressão. Sob esta concepção o campo da autonomia inclui não só a capacidade do cidadão se autosuprir, desde o mínimo de sobrevivência até necessidades mais específicas, como a de usufruir de segurança social pessoal mesmo quando na situação de recluso ou apenado. É este o campo dos direitos humanos fundamentais." (Sposati, 2000:5)

Com relação à qualidade de vida, o conceito apresentado por Sposati (2000) envolve duas grandes questões: a democratização dos acessos e à condição de preservação do homem e do meio ambiente. Com essa definição a autora explicita a importância da qualidade ambiental implícita no conceito e considera que, 
"a qualidade de vida é a possibilidade de melhor redistribuição - e usufruto - da riqueza social e tecnológica aos cidadãos de uma comunidade; a garantia de um ambiente de desenvolvimento ecológico e participativo de respeito ao homem e à natureza, com o menor grau de degradação e precariedade." (Sposati, 2000:5)

O Desenvolvimento Humano é outro conceito empregado na construção do índice, baseado no estudo do desenvolvimento humano que tem sido realizado pela ONU/PNUD, por meio do Indicador de Desenvolvimento Humano (IDH), apresentado no início deste capítulo. A autora entende que o desenvolvimento humano seja a possibilidade de todos os cidadãos de uma sociedade melhor desenvolverem seu potencial com menor grau de sofrimento; ou seja, poder usufruir coletivamente do mais alto grau do desenvolvimento humano. (Sposati, 2000)

E por fim, a equidade que é a efetivação com igualdade dos direitos da população:

"É a possibilidade das diferenças serem manifestadas e respeitadas, sem discriminação; condição que favoreça o combate das práticas de subordinação ou de preconceito em relação às diferenças de gênero, políticas, étnicas, religiosas, culturais, de minorias etc." (Sposati, 2000:6)

Para a elaboração do mapa em si, a autora ainda considerou as seguintes dimensões: Cidadania, Democracia e Felicidade. E complementa com a seguinte afirmação, "O referencial da utopia de inclusão social é uma construção qualitativa que no caso do Mapa supõe sete campos, nem todos mensuráveis". (Sposati, 2000:5)

O Índice Paulista de Responsabilidade Social (IPRS) foi criado pela Fundação SEADE no Fórum São Paulo - Século XXI solicitado pelos participantes que requereram a construção de indicadores sintéticos que permitissem captar a progressão do desenvolvimento dos municípios paulistas, de forma contínua. Torres, Ferreira e Dini (2003) afirmam que:

"A construção desse novo indicador de desenvolvimento reflete a estreita relação com os debates em torno da mensuração da qualidade de vida. A rigor, 
um indicador sobre esse tema se baseia na admissão de que a qualidade de vida não se resume à esfera econômica da experiência humana." (Torres et al., 2003:81)

O IPRS é um indicador, segundo os autores, que possui certas especificidades: preserva as três dimensões que compõem o IDH (renda, longevidade e escolaridade) visando o interesse de se manter consistente com o paradigma do desenvolvimento humano proposto pelo PNUD; incluem variáveis que são de certa forma, capazes de captar mudanças de curto prazo; e baseia-se em registros administrativos, devido sua cobertura e a periodicidade das fontes de dados, que permitiria a sua atualização para os anos intercensitários e para todos os municípios do Estado.

Os indicadores sintéticos foram criados nos diferentes anos (1992, 1997, 2000) para cada uma das três dimensões propostas: renda, longevidade e escolaridade. Esses indicadores estão expressos em uma escala que varia de 0 a 100 e se constituem de uma combinação linear para compor o indicador sintético (IPRS). A ponderação foi obtida por meio de um modelo de análise fatorial que estuda a estrutura de interdependência entre diversas variáveis.

A tipologia de municípios criada constitui-se em ferramenta analítica que permite a identificação da situação de cada um dos municípios paulistas em cada uma das três dimensões de análise. Essa tipologia foi criada por meio de técnicas estatísticas multivariadas que agrupam os municípios de acordo com as similaridades existentes.

Em 2003, o Centro de Estudos da Metrópole em parceria com a Secretaria de Assistência Social da cidade de São Paulo, lançaram o Mapa da Vulnerabilidade Social, visando detectar diferentes condições de carências sociais por meio da análise da distribuição da estrutura socioeconômica no espaço urbano. A exposição de certas populações e áreas a diferentes situações de vulnerabilidade social foi abordada a partir da descrição das características socioeconômicas e demográficas dos setores censitários do município de São Paulo, a partir das informações fornecidas pelo Censo 2000. Os grupos foram gerados a partir da combinação da dimensão de privação socioeconômica com a de estrutura etária. (CEM, 2003) 
Carvalho et al (1997, apud in Morato, 2004) desenvolveram um método de classificação multivariado voltado para uma classificação socioeconômica de micro-áreas urbanas, por meio da utilização dos setores censitários IBGE do ano de 1996 da região metropolitana do Rio de Janeiro (RMRJ). Foram selecionados primeiramente quinze indicadores considerados de grande poder explicativo da variância observada e por fim foram selecionados setes indicadores finais. A classificação gerou cinco tipos diferentes de setores: alta renda, renda mais baixa e pobre, com predomínio de casas alugadas, baixa renda; escolaridade e precariedade no saneamento básico. Os autores consideraram o método simples e eficaz para apontar a desigualdade na distribuição dos recursos, mapeando as grandes regiões de pobreza.

Souza (2006) apresenta em parceria com o Laboratório de Geoprocessamento da PUC-SP a construção de um indicador socioambiental para o município de São Paulo. Dois elementos nortearam a construção do indicador: o IPVS, Índice Paulista de Vulnerabilidade Social (criado pela Fundação SEADE para a Assembléia Legislativa) e as bases de informações ambientais do Atlas ambiental do Município de São Paulo, elaborado pela Secretaria municipal do Verde e Meio Ambiente.

Esse índice socioambiental, ISSa, testou uma metodologia onde foram cruzados dois indicadores consagrados o IPVS e um conjunto de informações que caracterizassem suscetibilidade ambiental. A escolha do IPVS deu-se pelo fato dele sintetizar de modo bastante satisfatório as condições socioeconômicas e demográficas da população do Estado de São Paulo. Dentre as informações existentes no Atlas Ambiental do Município de São Paulo optou-se por três dimensões consideradas as mais expressivas: suscetibilidade à inundação, escorregamentos de encostas e o desconforto térmico causado pelos efeitos da "ilhas de calor". A escolha dessas variáveis deveu-se ao fato da primeira expressar uma alteração no ambiente causado por uma lógica de urbanização que provocou profunda segregação espacial e, as duas outras, porque expõem as pessoas a situações de risco causado por choques representados pela dimensão ambiental e ato construtivo.

Para a construção do ISSa foram imputadas as informações ambientais na base de setores censitários, sobrepondo a cartografia dos setores censitários classificados segundo os grupos do IPVS. Para esse processo foram utilizadas 
ferramentas existentes nos SIGs (Sistemas de Informações Geográficas) que permitem a migração de um banco de dados espacial para outro, por meio da função overlay.

O ISSa mostra a pertinência da construção de um indicador sintético que revela a situação da suscetibilidade ambiental das populações residentes na cidade de São Paulo, tendo como pressuposto a utilização de variáveis que expressem a complexidade das relações entre sociedade e natureza, dadas na cidade.

Morato (2004) elaborou um índice para a avaliação da qualidade de vida em áreas urbanas, para isso, baseou-se nos critérios das necessidades básicas, adotando as necessidades mínimas. Foram analisadas três dimensões: a qualidade ambiental, o nível sócio-econômico e a educação. E distribuídas conforme figura abaixo:

Figura 5: Estrutura, fonte de dados e indicadores para o Índice de Qualidade de Vida Urbana

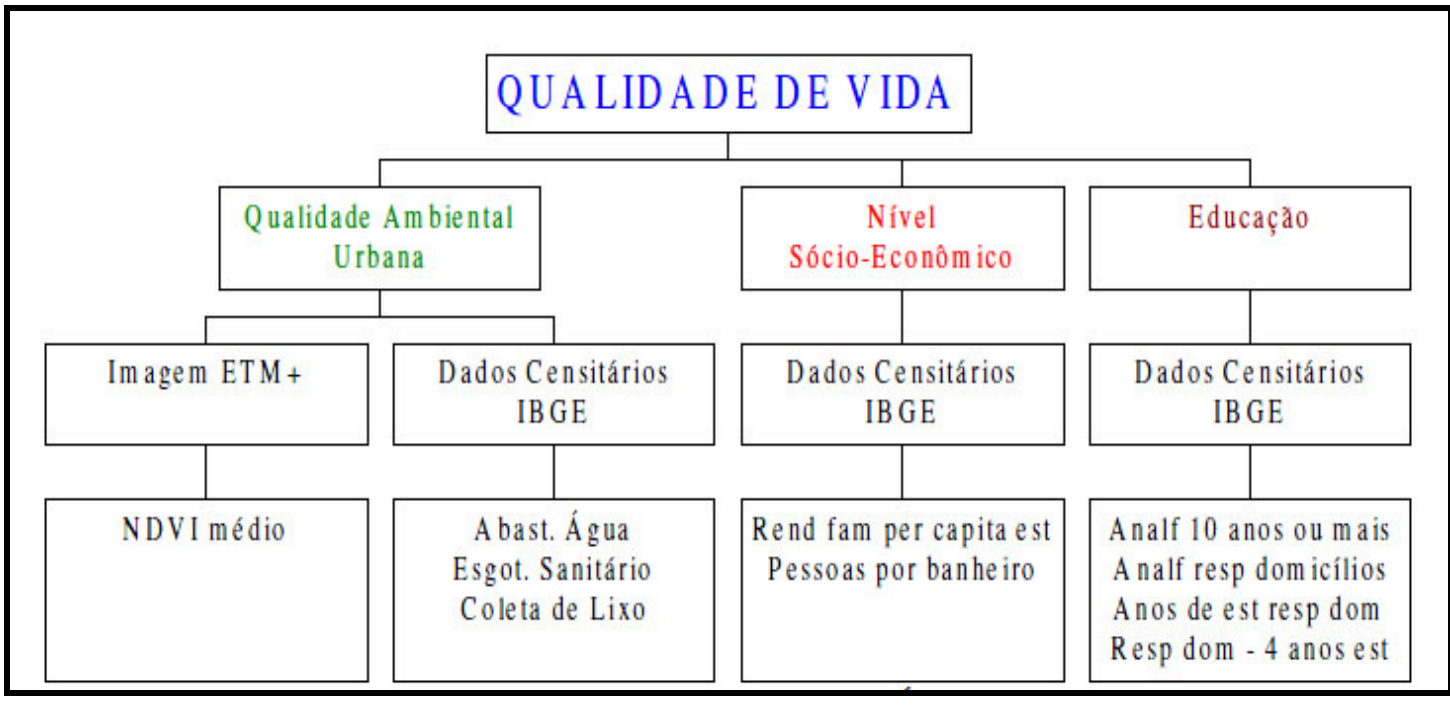

Fonte: Análise da Qualidade de Vida Urbanano Município de Embu - SP, Morato (2004), página 56.

Para cada indicador explicitado na figura acima, foram atribuídos pesos diferentes e calculados por meio de média aritmética.

A mensuração da qualidade de vida, pela criação de um índice, baseia-se na afirmação de que a mesma não se resume à esfera econômica. As definições dos indicadores de qualidade de vida abordam questões metodológicas, que dizem respeito à forma adotada de representação, bem como às técnicas adotadas e seus critérios. 
Guimarães e Jannuzzi (2004:1) ao analisar a construção de indicadores sintéticos, como são os indicadores de qualidade de vida observam que:

"Procurando adaptar-se a esse novo contexto institucional na formulação e avaliação de políticas públicas, municípios e agências governamentais têm investido tempo, recursos humanos e financeiros na organização de sistemas de informações estatísticas municipais, em alguns casos bastante sofisticados, pacotes estatísticos, construção de indicadores sintéticos para diagnóstico social e focalização de políticas. Entretanto, os aspectos conceituais e metodológicos para a construção dos índices de medição tanto da pobreza quanto dos níveis de vida e do desenvolvimento humano e/ou socioeconômico - ainda que elaborados por instituições respeitadas revelam problemas que ainda não foram devidamente superados, carecendo de aprofundamento analítico efetivo no uso dos mesmos no processo de formulação e avaliação de políticas públicas."

Deste modo, Napoleão (2005) ressalta a questão dos objetivos pretendidos com a construção de indicadores sociais. Pois além de representar sinteticamente a realidade espaço-temporal de um determinado grupo social, o seu uso tem de ser efetivo pelos formuladores de políticas públicas, subsidiando as etapas necessárias dos processos de avaliação, construção e implantação dessas políticas.

"Assim, quando um gestor de políticas públicas pretende utilizar um indicador como ferramenta de avaliação e acompanhamento da política social, algumas questões importantes precisam ser analisadas, como a produção de indicadores para pequenas áreas, se este indicador é sensível a variações de curto prazo, isto é, condizente com o tempo de execução da política social." (Napoleão, 2005:48).

Do ponto de vista das limitações dos índices, em relação ao IDH Jannuzzi (2004) destaca a vinculação do índice ao plano das políticas públicas que guarda uma relação direta com um superdimensionamento do mesmo, arraigado em um processo de negligenciamento no qual o indicador nada mais é senão uma medida operacional de um conceito. Segundo o autor, está se consolidando uma 
prática: a substituição do conceito indicado pela medida supostamente criada para operacionalizá-lo.

Guimarães e Jannuzzi (2004:5) ainda destacam:

"A "reificação" da medida em detrimento do conceito tem outro desdobramento muito preocupante sobre o campo da formulação de políticas, que é o de reforçar a tendência de encará-la como isenta de valores ideológicos ou políticos, como se na sua construção não interviessem orientações teóricas e opções metodológicas dos seus proponentes".

É reconhecido o fato de que a introdução do IDH nas tomadas de decisões em políticas públicas destacou a importância da melhoria das condições de educação e saúde da população para os gestores e também sinalizou que o alcance do progresso não se resume e nem é sinônimo de crescimento econômico. Entretanto, o que se procura destacar é que embora os índices sejam instrumentos importantes para as políticas públicas, eles apresentam limitações que não devem ser desprezadas, mas que em linhas gerais apresentam um retrato da situação de um determinado lugar. Mas conforme destaca Jannuzzi (2004), por si só a disponibilidade de ferramentas e a construção de novos indicadores não garantem uma melhor gestão dos recursos e implementação de programas sociais.

\subsubsection{EVOLUÇÃO DEMOGRÁFICA DA CIDADE DE SÃO PAULO E OS CENSOS DEMOGRÁFICOS}

São Paulo em 1554, ano de sua fundação, não contava com mais de 100 habitantes que viviam nos arredores do Pátio do Colégio, onde se formou o núcleo inicial da cidade.

Em 1870 quando ocorreu o primeiro levantamento censitário do Brasil, o quadro havia se alterado, a cidade já contabilizava 31.385 moradores. Até o final do século XIX a cidade passou da condição de vila afastada dos grandes centros comerciais, para assumir a importância crescente como entreposto comercial e ponto de entroncamento das rotas pelas quais era escoada a produção cafeeira. Em vista dessa posição, a cidade passou a atrair um contingente significativo de 
imigrantes europeus, direcionados inicialmente para substituir a mão-de-obra escrava na lavoura cafeeira, mas posteriormente, muitos deles acabaram se fixando na capital ou retornando a ela após algum tempo.

O processo de industrialização da cidade de são Paulo iniciou-se por volta da década de vinte do século passado, mais foi por volta da década de cinqüenta, já com os fluxos de imigração estrangeira bastante reduzidos, e ao mesmo tempo, com o grande impulso industrial que a cidade passa a atrair contingentes populacionais de outros Estados do país, transformando-se no maior pólo de migração interna.

Entre 1950 e 1980 foram mais de três milhões de trabalhadores e suas famílias que chegaram à cidade de São Paulo. Este processo aliado ao crescimento vegetativo da população manteve taxas elevadas de crescimento da cidade de 4 a $5 \%$ ao ano.

A partir da década de 1970, com o início do processo de desconcentração industrial, e a conseqüente redução do número de empregos no setor secundário da economia, viu-se também uma diminuição do poder de atração populacional da cidade, que passa a apresentar saldos migratórios negativos. Nesta época a cidade já contava com cerca de seis milhões de habitantes. Na década de 800 crescimento vegetativo também é afetado em virtude da diminuição dos índices de fertilidade e de natalidade da população brasileira. Esse quadro contribuiu para uma acentuada redução do crescimento demográfico, chegando a índices de 1,2\% ao ano. Desde a década de 1990 o aumento populacional da cidade tem se pautado por um lento crescimento vegetativo, que não impede a expansão da aglomeração urbana para as áreas periféricas, incluindo as zonas de proteção aos mananciais.

São Paulo contabiliza atualmente, 11 milhões de habitantes distribuídos em 1523 km2 (IBGE, 2000). Até a década de 1980, todas as regiões da cidade apresentavam crescimento populacional positivo, com exceção do núcleo central formado pelos distritos de Belém, Bom Retiro, Brás e Pari. Desde então, ocorreu nas adjacências destes distritos uma redução populacional que fora verificada pelas taxas negativas de crescimento apresentadas pela região. Durante a década de 90 esse processo se intensificou e aproximadamente $60 \%$ dos distritos do município passaram a apresentar perda populacional. Neste mesmo período os distritos que passaram a apresentar crescimento populacional positivo foram 
àqueles situados nas áreas mais extremas da cidade, indicando que o processo de periferização ultrapassou os limites municipais.

Os censos demográficos produzem informações imprescindíveis para definição de políticas públicas ou investimentos provenientes das esferas públicas ou privadas. Os censos constituem atualmente a única fonte de referência sobre a situação de vida da população dos municípios e sobre as divisões internas dos mesmos, tais como, distritos, aglomerados, bairros e localidades rurais ou urbanas. (IBGE, 2000)

No Brasil, os censos demográficos vêm sendo realizados desde 1872 antes dessa data os dados sobre a população brasileira eram feitos de forma indireta, isto é, não havia um órgão responsável pelos levantamentos, eles eram coletados pelas igrejas ou eram feitas estimativas pelos ouvidores ou outras autoridades. Os primeiros censos foram respectivamente em 1872 e 1900 e preocuparam-se basicamente com a contagem populacional.

O IBGE (Instituto Brasileiro de Geografia e Estatística) foi fundado em 1936 e passou a ser a entidade responsável pela realização dos censos demográficos. Foi a partir deste período que se inaugura a fase moderna da coleta censitária no país que contou com a contribuição do demógrafo italiano Giorgio Mortara. Desde 1940 os censos se tornaram decenais, neste momento foram incorporados nos questionários uma maior abrangência temática acerca das características socioeconômicas da população. Desde então, os censos passam por um contínuo processo de aperfeiçoamento que possibilita atualmente um retrato mais coerente do Brasil.

De acordo com o IBGE o censo demográfico tem por objetivo contar os habitantes do território nacional, identificar suas características e revelar como vivem os brasileiros (IBGE, 2000).

Para o levantamento das informações são utilizados dois questionários: básico e o da amostra. O primeiro contém informações sobre as condições de habitação, número de banheiros, valor do aluguel, telefonia, responsável pelo domicílio, parceiros do mesmo sexo e idade. O segundo contém as informações do primeiro, agregadas às demais relativas à união conjugal com pessoa que não mora no mesmo domicílio, mortalidade, cor ou raça, religião, pessoas portadora de deficiência, migração, deslocamento trabalho ou estudo, trabalho e rendimento, fecundidade e educação. 
As informações são coletadas pelos recenseadores percorrendo os setores censitários, que é a unidade de controle cadastral formada por uma área contínua urbana ou rural, cuja dimensão e número de domicílios sejam viáveis para o recenseador cumprir suas atividades no prazo determinado.

Em 2000, ano do último Censo Demográfico realizado nos municípios, o Distrito da Cachoeirinha contava com 157 Setores Censitários.

As informações acerca da população residente de cada setor tornam-se bastante precisas com a coleta realizada pelo IBGE, bem como as informações socioeconômicas relativas também aos domicílios, as quais serviram de base para se produzir o mapa síntese de qualidade de vida do Distrito de Cachoeirinha.

\section{CAPÍTULO 4}

\section{ÁREA DE ESTUDO}

É a partir da década de 1970 que se intensifica o processo de concentração de renda e a lógica construtiva da cidade, acentua o processo de deslocamento das centralidades e a conseqüente exclusão da população mais pobre, gerando assim a periferização e a favelização. Segundo dados do Atlas Ambiental do Município (SVMA, 2000) em 1973 apenas 1\% da população de São Paulo moravam em favelas, na década de 80 esse número salta para $4 \%$ e na década seguinte para $8 \%$.

O século XXI inicia-se com a crise da metrópole, marcada pela crescente exclusão social da grande maioria de sua população de 10 milhões de habitantes e pela degradação ambiental.

O recorte espacial dado pelo limite político e administrativo do distrito da Cachoeirinha se deu devido ao fato da sua localização, no limite urbano da cidade ao norte representado pela Serra da Cantareira. Devido também à predominância do uso residencial horizontal principalmente de médios, baixos padrões na região (SVMA, 2000) e a importância que a unidade de análise distrito representa em nível municipal para o planejamento que, segundo a lei Orgânica do Município de São Paulo de 1991 estabelece a divisão distrital como definidora de unidades de planejamento. 
- "Art 157: O município instituirá a divisão geográfica de sua área em distritos, a serem adotados como base para a organização da prestação dos diferentes serviços públicos." (LO - MSP, 1991 apud in Nucci, 2001)

Os bairros que compõem o distrito da Cachoeirinha de acordo com 0 conjunto de dados disponibilizados pela base digital do município de São Paulo, o GEOLOG (2002) são: Vila Dionisia, Vila Bela Vista, Vila Continental, Pedra Branca, Sítio Casa Verde, Jardim Peri, Jardim Peri Alto, Jardim Peri Baixo, Jardim Peri Velho, Jardim Peri Novo, Alto do Jardim Peri,Jardim Antártica, Cohab Jardim Antártica, Vila Roque, Jardim Santa Cruz, Jardim Elisa Maria, Jardim Ceci, Jardim Ondina, Ladeira Rosa, Parque Tietê, Jardim Teresa e Vila Rica. Os bairros da cidade de São Paulo não são áreas passíveis de delimitação, pois, não existe um mapeamento oficial dos mesmos, elaborado pela prefeitura ou por qualquer órgão oficial. 
Mapa 2: Localização da Área de Estudo na Região Metropolitana de São Paulo.

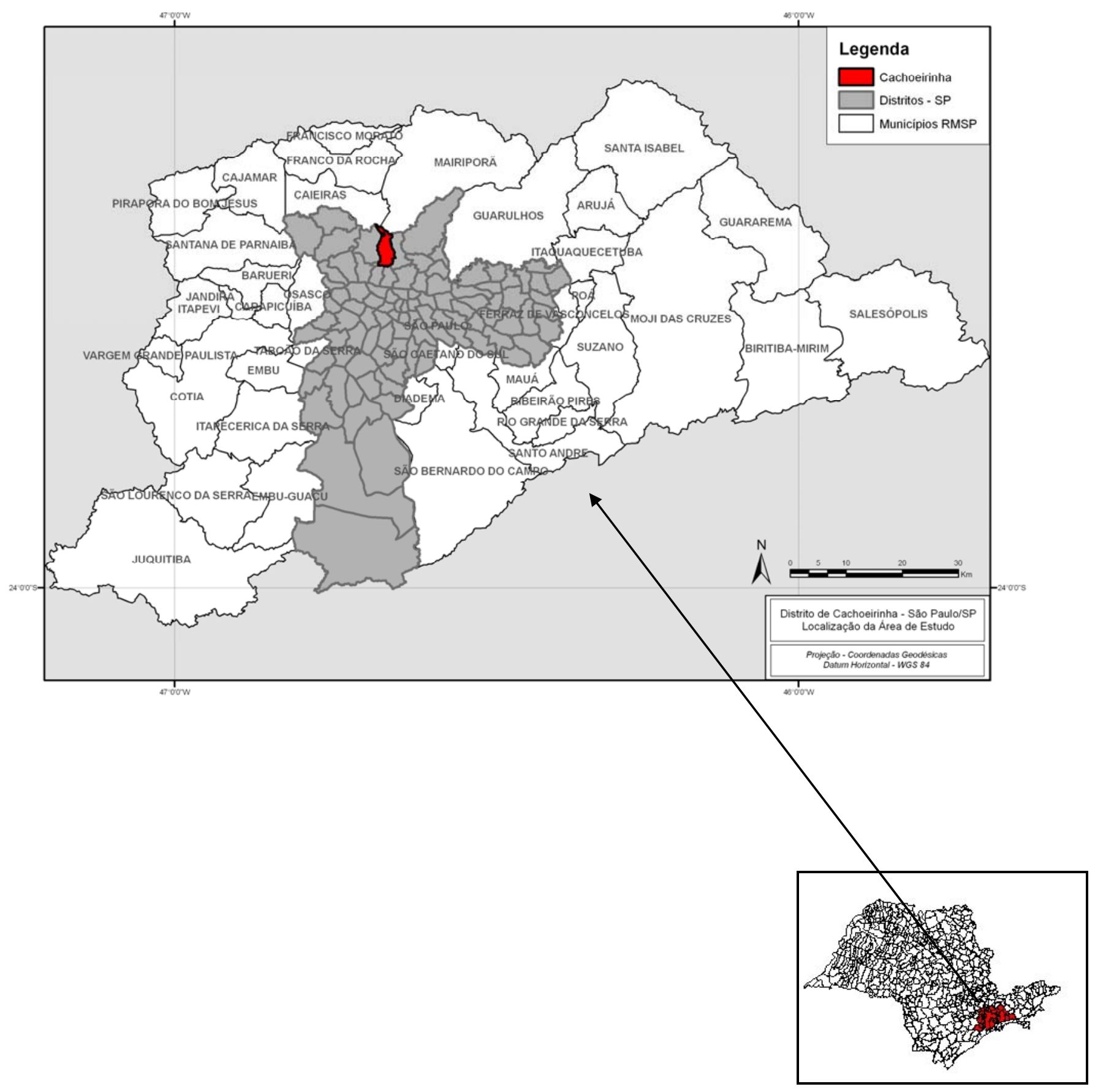

Fonte: Geolog, 2000. Elaborado pela autora, 2007. Elaborado pela autora, 2008 
Mapa 3: Localização da Área de Estudo no município de São Paulo.

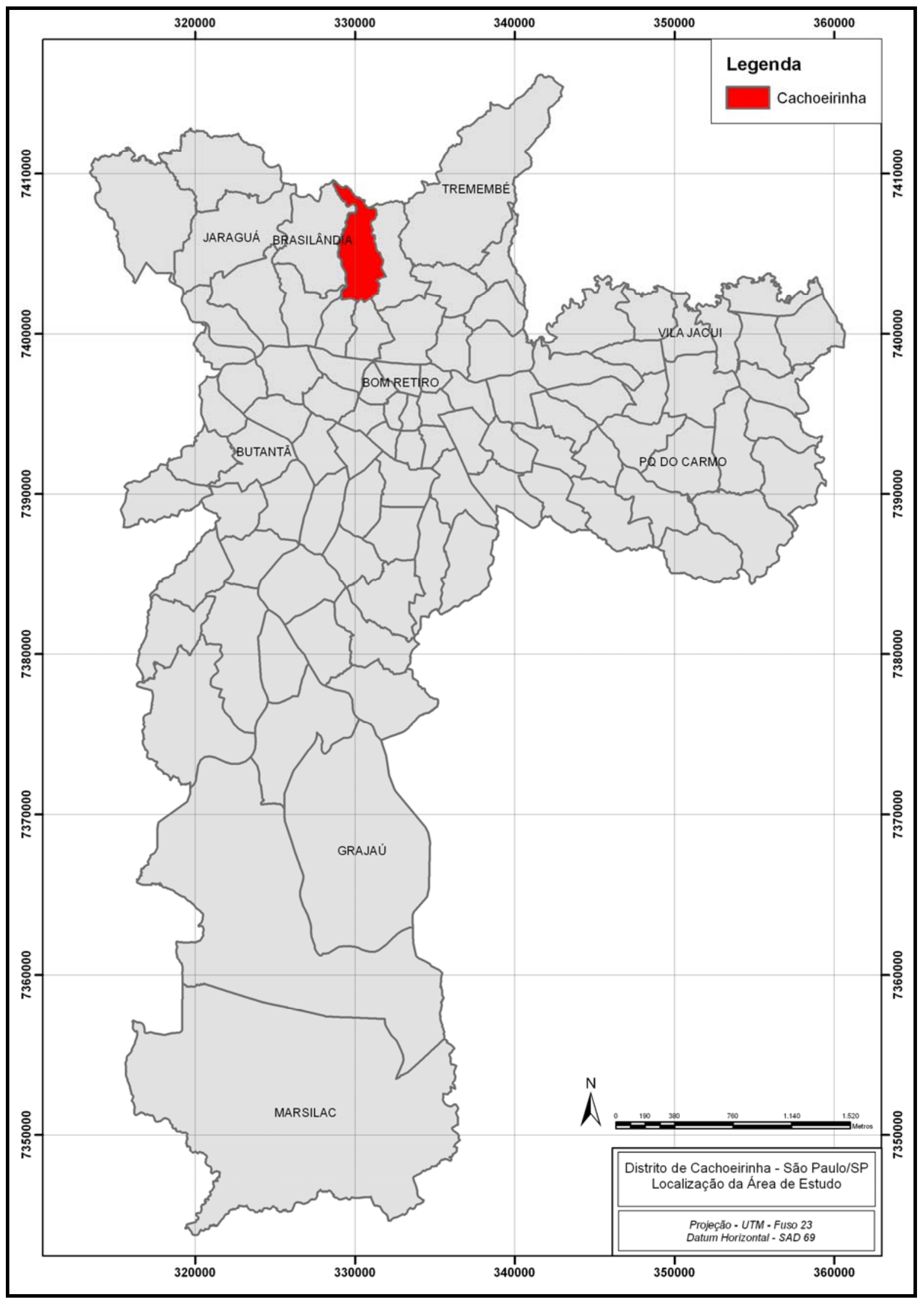

Fonte: Geolog, 2000. Elaborado pela autora, 2007. 
Mapa 4: Localização dos Bairros no Distrito de Cachoeirinha

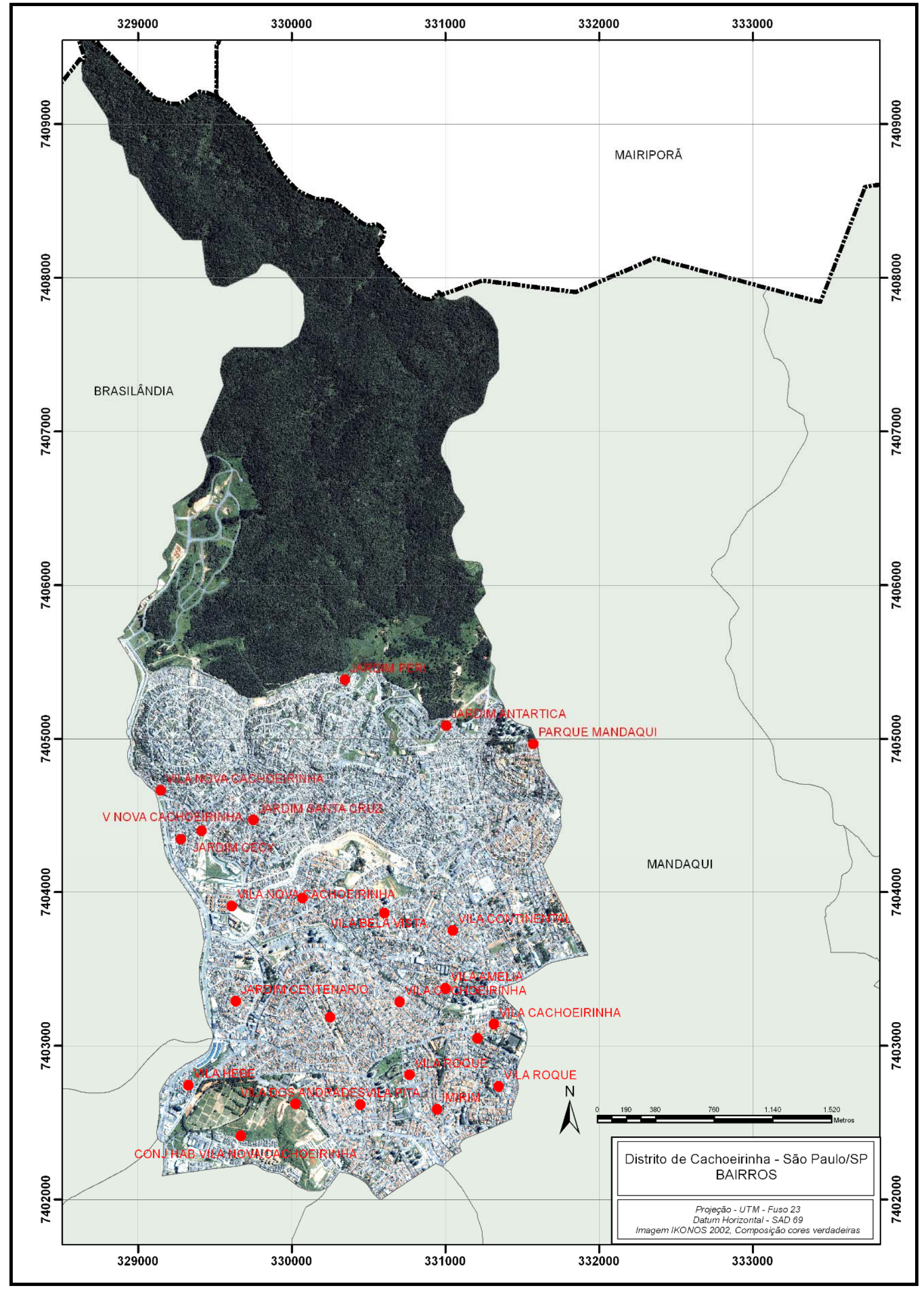

Fonte: Geolog, 2000 e Imagem Ikonos composição cores verdadeiras. Elaborado pela autora, 2007. 
Bairro Jardim Peri é um dos que compõem o distrito e faz divisa com o Parque Estadual da Cantareira. Dentre os muitos problemas do bairro um dos principais é a extrapolação de seus limites físicos territoriais para a área de proteção ambiental do Parque da Cantareira. Esta expansão ocorre sem planejamento e, portanto, a ocupação se dá de acordo com as necessidades dos moradores e sem critérios técnicos adequados.

De acordo com dados levantados sobre o local (Jornal Freguesia News/Santana News/Folha do Limão - 06 de agosto de 2000), na gestão municipal da Prefeita Marta Suplicy, em função da obra de pavimentação e ampliação da Av. Afonso Lopes Vieira, barracos tiveram que ser derrubados e a população foi removida para um conjunto habitacional em um bairro vizinho, o Jaraguá. No entanto, sendo a população residente na região extremamente carente e sem condições financeiras para pagar as contas de condomínio (água, luz...), já que antes não pagavam; muitas famílias retornaram ao bairro e começaram a ocupar áreas abandonadas, construindo novos barracos.

Conforme Marques e Saraiva (2005) explicitam em São Paulo, Pobreza e desigualdades sociais, as políticas habitacionais podem interferir de maneira positiva ou negativa sobre os processos de segregação espacial. Positiva quando o Estado consegue reduzir a segregação ao construir habitação social em locais que é baixa a presença de grupos sociais de baixa renda. Negativa, quando o Estado pode reforçar a segregação, ao construir empreendimentos para grupos sociais pobres em locais já segregados espacial e socialmente, como foi exemplificado no Jardim Peri. Além de não solucionar o problema, voltou-se à estaca zero. Mas, de acordo com os mesmos autores citados acima, o modelo de produção pública de moradia que vem sendo empregado desde a metade do século $\mathrm{XX}$ pouco tem impactado sobre o crescimento das desigualdades sociais em nossas metrópoles. Além disso, por serem os terrenos urbanos muito caros, as localizações escolhidas para serem implantados os conjuntos foram sempre glebas situadas nas fronteiras das cidades, sem a intenção de promover uma integração com a malha urbana existente, sem infra-estrutura adequada e com enormes custos de transportes. Esses fatores geram efeitos negativos sobre a segregação territorial urbana.

Monteiro et al., 2007 também reforçam o impacto negativo da realocação de pessoas que vivem em áreas consideradas de risco. Para os autores, entre os 
casos clássicos, é a realocação dessas pessoas nas periferias das cidades, para ocupar áreas precárias com baixa qualidade ambiental e de vida, que agrava a exclusão social e a segregação espacial dos centros urbanos.

O distrito de Cachoeirinha faz parte da administração da subprefeitura Casa Verde/Cachoeirinha e Limão. No último plano diretor aprovado para 0 município de São Paulo (Lei no 13430 SET/2002), dentre as diversas melhorias previstas para a cidade está a implantação de parques lineares:

- Art. 57: II - implantar parques lineares dotados de equipamentos comunitários de lazer, como forma de uso adequado de fundos de vale, desestimulando invasões e ocupações indevidas.

De acordo com o boletim da subprefeitura citada, datado de março de 2007 "um novo parque está a caminho", são as margens do córrego do Bispo que serão transformadas no parque linear. O boletim afirma que esse parque será construído visando à proteção do leito do córrego e também ajudará a população aprender "coisas" importantes a respeito da natureza. Há um destaque interessante para a proibição de despejo de lixo no local e para a limpeza. O córrego corre em paralelo com a área limítrofe do Parque Estadual da Cantareira.

Certamente, a implantação desse parque causará um impacto positivo nas margens do córrego. Há que se pensar, entretanto, que sua manutenção e policiamento sejam realmente eficazes para desestimular as ocupações irregulares previstas na lei e também ressaltadas no boletim, que apesar da lei estar voltada à preservação do meio ambiente, novamente ela reforça o lado segregacionista das políticas públicas, destacando as ocupações irregulares como um dos principais propulsores da destruição do meio ambiente.

Em 19 de Julho de 2007 a subprefeitura de Casa Verde/Cachoeirinha, iniciou a operação defesa das águas, uma parceria da prefeitura municipal e do governo do estado, visando recuperar e urbanizar matas, córregos e nascentes da zona norte da cidade. Foram removidas residências consideradas ilegais por estarem localizadas na APA (área de preservação ambiental) dentro do parque, galpões e edificações utilizadas para guardar animais. Para que não houvesse atrito, a operação contou com Polícias Militar, Militar Florestal, Civil, Guarda Civil Metropolitana e GCM Ambiental num total de 200 policiais. 


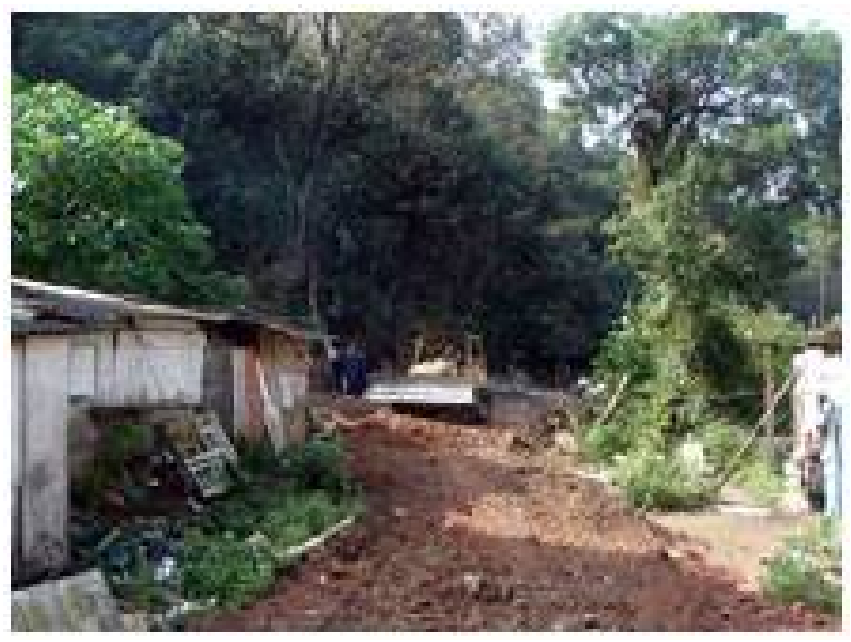

Foto 1: Operação Defesa das águas 19/07/2007. Foto extraída do site: www6.prefeitura.sp.gov.br/noticias

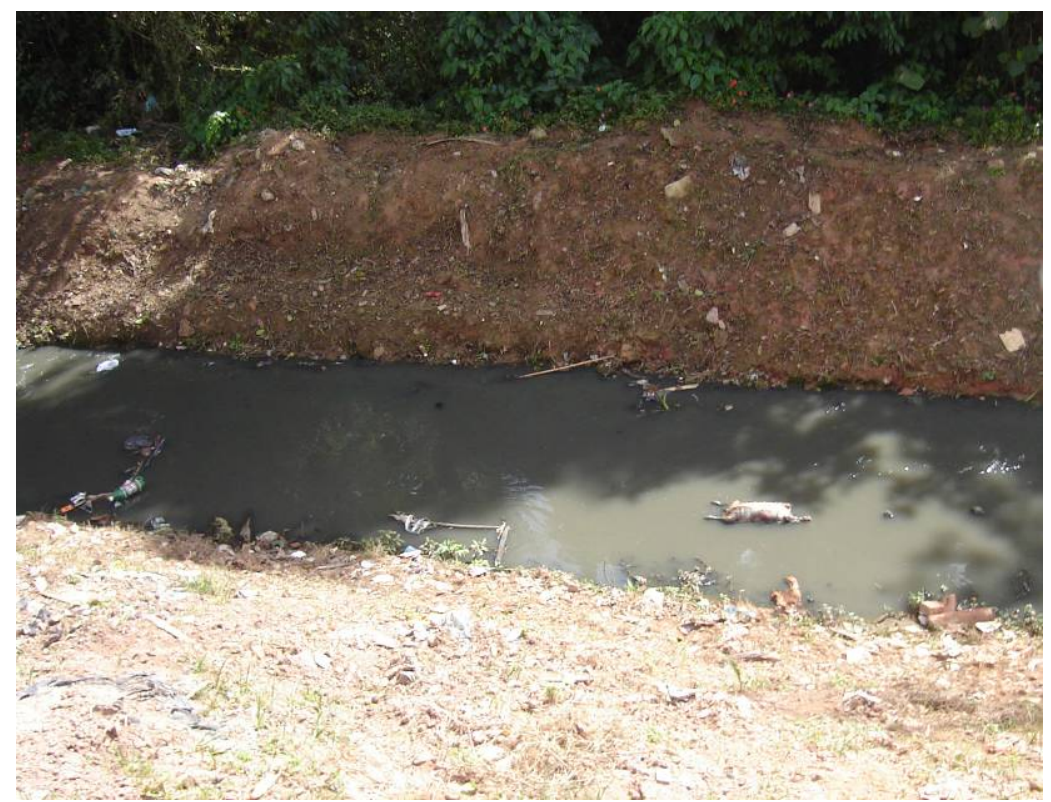

Foto 2: Córrego do bispo. Autor: Eric Massa, agosto de 2006. Bairro Jardim Peri, limite com o Parque Estadual da Cantareira. 


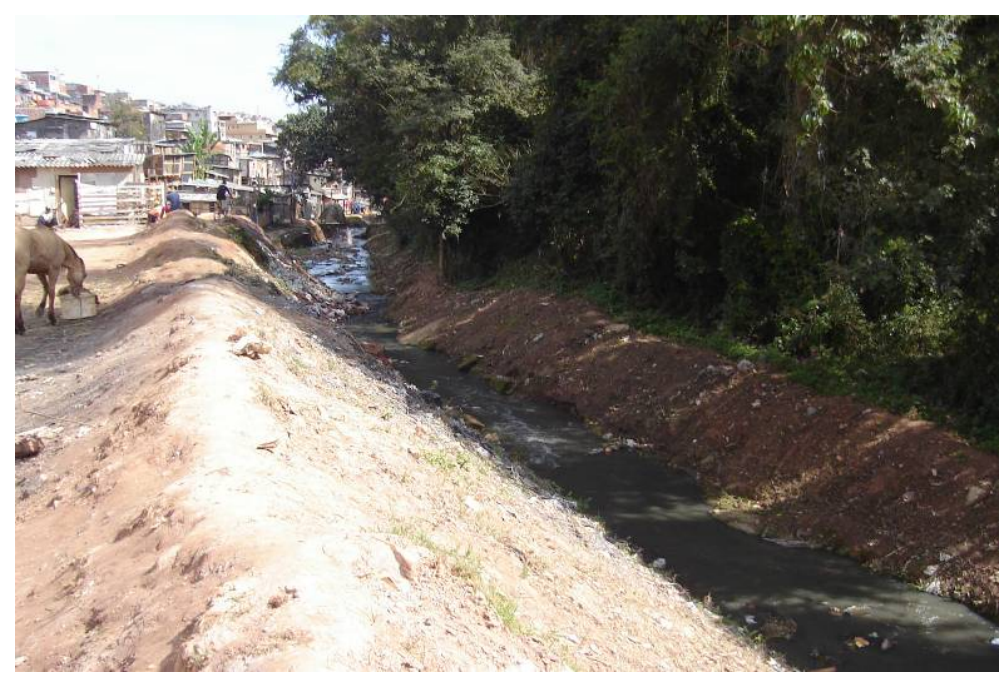

Foto 3: Córrego do bispo. Autor: Eric Massa em agosto de 2006. Bairro Jardim Peri, do lado direito da foto as autoconstruções e do lado esquerdo as árvores da APA.

As fotos acima demonstram a falta de opção para muitos moradores da cidade, que se fixam em locais inadequados representado pelos riscos. A resolução CONAMA 369 (Conselho Nacional do Meio Ambiente), Seção IV da Regularização Fundiária Sustentável de Área Urbana trata em seu Art. 9० A intervenção ou supressão de vegetação em APP para a regularização fundiária sustentável de área urbana poderá ser autorizada pelo órgão ambiental competente, observado o disposto na Seção I desta Resolução, além dos seguintes requisitos e condições:

a) nas margens de cursos de água, e entorno de lagos, lagoas e reservatórios artificiais, conforme incisos I e III, alínea "a", do art. 3o da Resolução CONAMA nº 303, de 2002, e no inciso I do art. $3^{\circ}$ da Resolução CONAMA n 302, de 2002 , devendo ser respeitada faixas mínimas de $15 \mathrm{~m}$ para cursos de água de até $50 \mathrm{~m}$ de largura e faixas mínimas de 50 m para os demais;

e) identificação das áreas consideradas de risco de inundações e de movimentos de massa rochosa, tais como, deslizamento, queda e rolamento de blocos, corrida de lama e outras definidas como de risco.

Além da falta de aplicação de leis regulamentadoras, esse tipo de ocupação apresenta riscos para a população. 


\subsection{CARACTERÍSTICAS DO DISTRITO DE CACHOEIRINHA, SEGUNDO CENSO IBGE, 2000}

\subsubsection{CONDIÇÕES DE HABITAÇÃO}

A habitação envolve o espaço físico no qual a pessoa vive e sua relação com o seu entorno. Certamente se as moradias não forem construídas adequadamente, no que diz respeito às técnicas, materiais e até mesmo espaços adequados, estas representarão uma piora nas condições de vida da população ou até mesmo um risco.

$\mathrm{Na}$ Cachoeirinha os aspectos observados com relação às habitações podem ser verificados no mapa das zonas residenciais homogêneas, apresentado no capítulo 6.1, esta foi uma caracterização geral apoiada em técnicas de sensoriamento remoto e de trabalho de campo para verificação posterior. Não foi realizado um trabalho de campo com vistas à caracterização geral dessas moradias no que diz respeito à iluminação, ventilação, aspectos construtivos, pois o mesmo fugiria do escopo da presente pesquisa.

Figura 6: Comparação entre os índices de habitação tipo cômodo na Cachoeirinha e na Cidade de São Paulo.

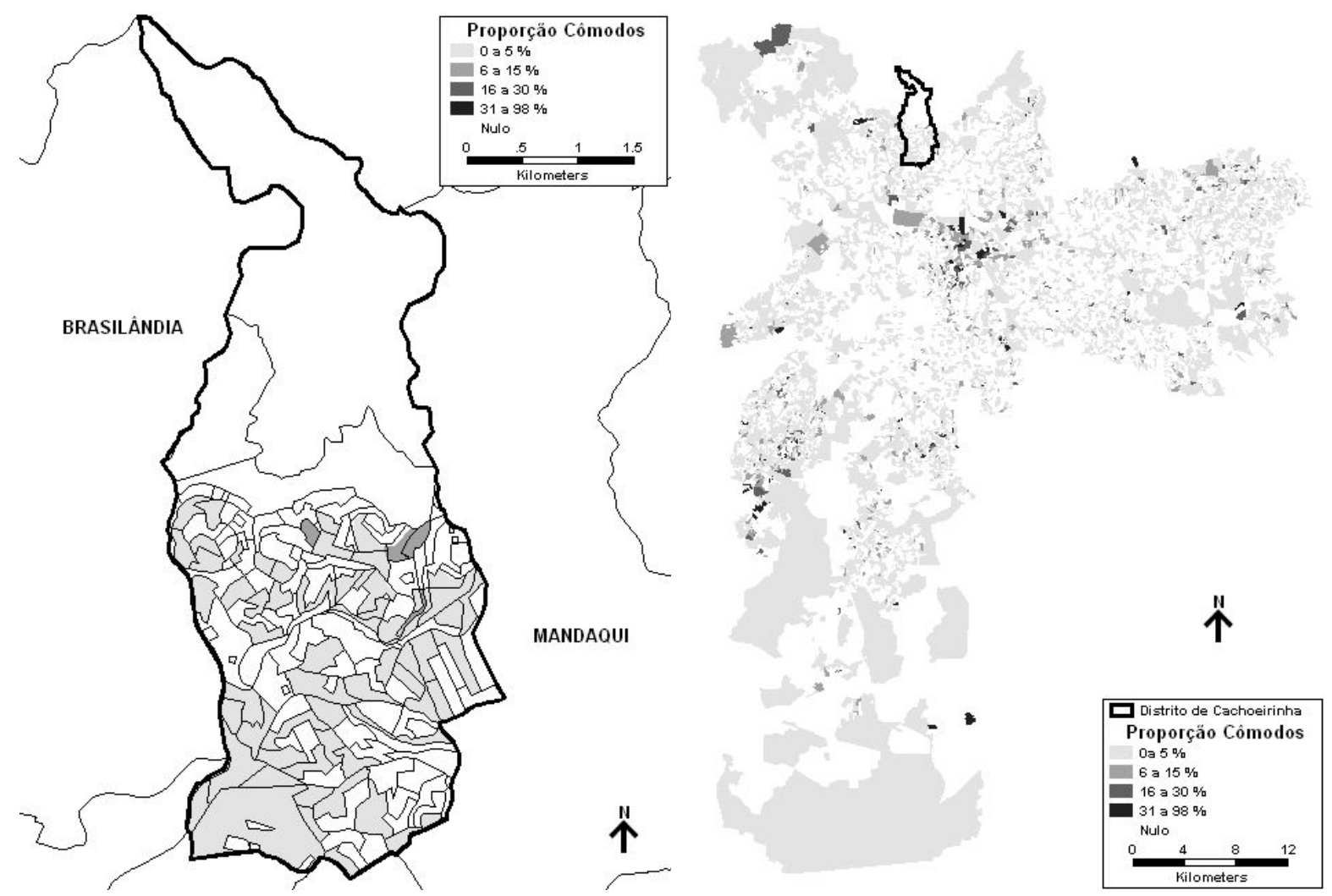


Com relação aos indicadores construídos a partir das variáveis do censo demográfico (IBGE, 2000), foi possível verificar que os domicílios tipo cômodo são escassos no distrito de Cachoeirinha e também no município de São Paulo. Porém, esse dado foi selecionado, devido ao fato da possibilidade de verificação de domicílios encortiçados, algo que certamente afeta a qualidade de vida.

Comparando os mapas de proporção de domicílios tipo cômodo, é possível verificar que ambos apresentam baixos índices de domicílios classificados nesse tipo. Na Cachoeirinha de acordo com a tabela de variáveis dos mapas, o maior índice é de 13,04\% o que indica que existem poucos setores com poucos domicílios tipo cômodos. No município de São Paulo, a variação entre os dados é grande $0,09 \%$ a $97,45 \%$ de domicílios tipo cômodo. Sendo verificado que os índices mais elevados, de acordo com a tabela se encontram espalhados pela cidade e que apenas dezenove setores apresentam mais de $60 \%$ de domicílios tipo cômodos.

No distrito de Cachoeirinha, existem apenas quatro setores que se enquadram na segunda classe do mapa de proporção de cômodos (6 a 15\%) mostrando que esse indicador pouco auxiliará na análise da qualidade de vida no distrito. 
Figura 7: Comparação entre os índices de domicílios alugados na Cachoeirinha e na Cidade de São Paulo.

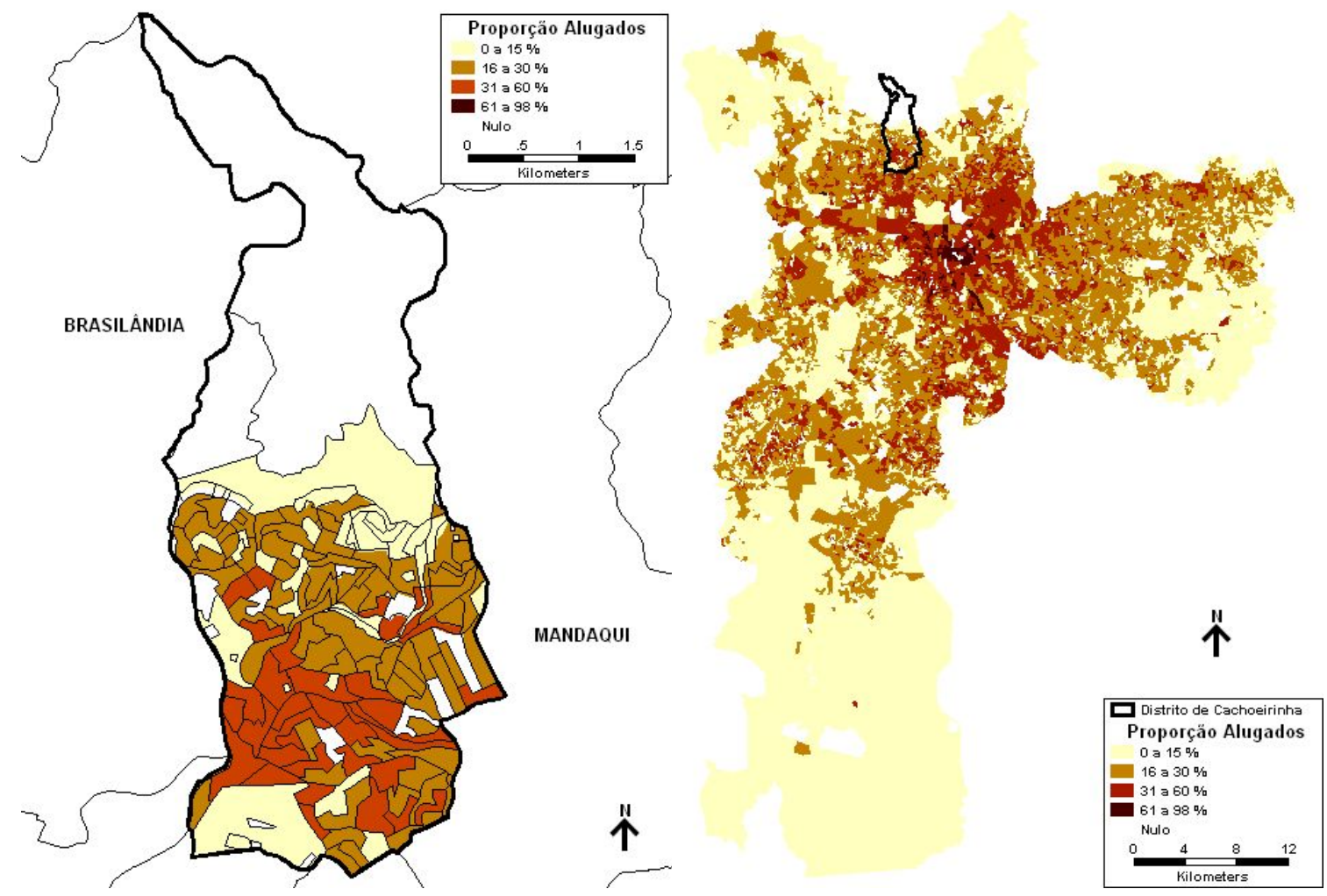

Fonte: Censo Demográfico 2000, IBGE.

Com relação à proporção de domicílios alugados no distrito de Cachoeirinha foi possível verificar na tabela de variáveis que o índice máximo atingido é de 50\%. Já na cidade de São Paulo como um todo o índice varia muito e atinge o máximo de 97\%. É possível observar no mapa da cidade que a proporção de imóveis alugados é muito maior nas áreas centrais do que na periferia. Isso pode ser explicado pela especulação imobiliária que encarece os imóveis melhores localizados, das áreas centrais em detrimento dos imóveis localizados nas áreas periféricas, onde a qualidade dos serviços de transportes, por exemplo, são piores. Outro fator importante a ser levantado é o fato de que nas áreas de "periferia extrema" ou as bordas da cidade, há pouca regularização dos lotes, as construções são geralmente pecarias e os moradores se consideram donos dos imóveis, porém, muitas vezes não possuem documentação nenhuma que comprove pelo menos a titularidade de seu lote. 
Figura 8: Comparação entre os índices de domicílios quitados na Cachoeirinha e na Cidade de São Paulo.

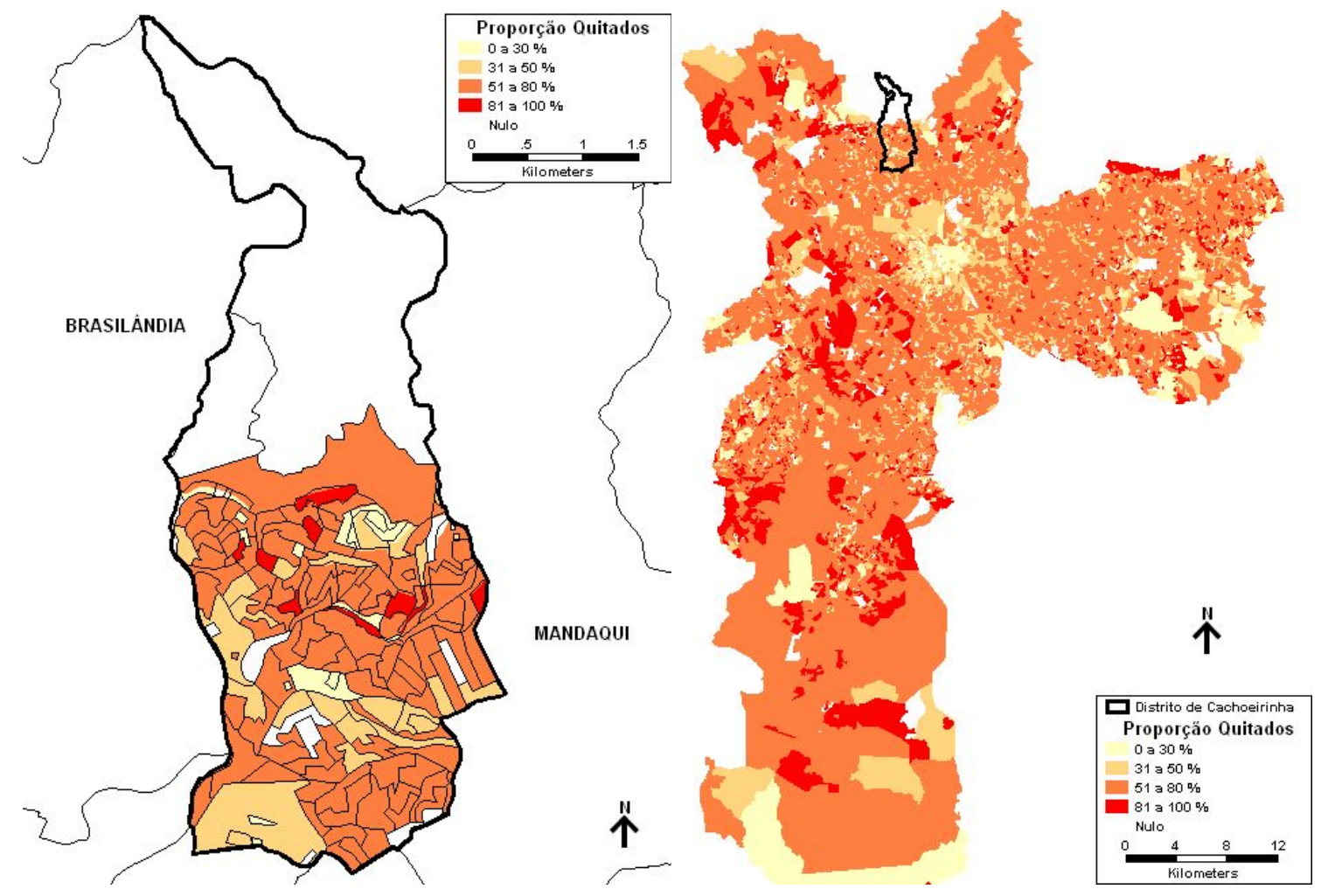

Fonte Censo Demográfico 2000, IBGE.

A última variável selecionada para expressar as condições de habitação do distrito de Cachoeirinha foi a proporção de domicílios quitados. Comparando o distrito estudado com a cidade de São Paulo, diferentemente dos mapas apresentados nesse capítulo, é possível observarmos que os índices decrescem no centro da cidade, mas no restante do município, não existe um padrão de distribuição, o mesmo ocorre no distrito de Cachoeirinha. Na cidade de São Paulo existem, segundo o censo demográfico 2000, mais de dez mil setores com mais de $50 \%$ dos imóveis quitados. No distrito de Cachoeirinha, é também possível observar a maioria dos setores na faixa com mais de $50 \%$ dos imóveis quitados.

E embora essas variáveis tenham sido de grande utilidade para o início da análise da área estudada, quando foi realizada a análise fatorial as mesmas não puderam ser utilizadas no modelo proposto devido à incompatibilidade dessas variáveis com outras consideradas mais importantes tais como, saneamento, renda e escolaridade. 


\subsubsection{CONDIÇÕES DE SANEAMENTO}

Essa síntese representa as condições de infra-estrutura urbana no que diz respeito ao saneamento básico. O saneamento é considerado como um conjunto de medidas que visa preservar ou modificar as condições ambientais de modo a promover saúde para a população por meio do controle e da prevenção de doenças, melhoria da qualidade de vida e das atividades econômicas.

A rede geral de abastecimento de água funciona como vasos comunicantes e é considerada como a condição mais adequada para o abastecimento nas áreas urbanas, tendo em vista a garantia de potabilidade da água assegurada pelos órgãos oficiais de saneamento básico. No município de São Paulo a empresa que atua nos serviços de água e esgoto é a SABESP que também está presente em outros 366 municípios do Estado. Segundo a SABESP, os índices de abastecimento, coleta e tratamento de esgoto no município de São Paulo, aproximam-se de $100 \%, 80 \%$ e $65 \%$ respectivamente.

A coleta de lixo domiciliar é também outro fator importante para o saneamento. A disposição do lixo interfere sobremaneira na vida de uma comunidade se esta não the der um destino adequado, lançando-o em rios, lagos, mares, ou até mesmo em terrenos baldios, pois essas atitudes expõem a população ao risco de contaminação. O destino mais adequado para o lixo são os aterros sanitários ou as estações incineradoras. Atualmente programas de reciclagem vêm sendo promovidos pela prefeitura municipal de São Paulo (PMSP), o "tecendo novos caminhos" incentiva empreendedorismo e a autosustentabilidade dos carroceiros, capacitando-os na área têxtil. O programa coleta seletiva solidária foi criado na gestão Marta Suplicy em 2000. Atualmente, das 10.000 toneladas de lixo geradas diariamente na cidade, apenas 1300 são recicladas. A coleta seletiva recolhe cerca de 70 toneladas por dia de resíduos que são destinados para 14 centrais de triagem, onde se realiza sua separação, prébeneficiamento e comercialização. As outras 1.230 toneladas/dia são predominantemente coletadas por milhares de catadores de materiais recicláveis, organizados ou não em cooperativas, associações, grupos que ganham à vida por meio desse trabalho.

O sistema de esgoto foi elaborado de modo a afastar a possibilidade de contato da população com os despejos e dejetos, da água de abastecimento. A 
conexão dos domicílios à rede geral e a disposição de fossas sépticas são as maneiras mais adequadas para se coletar o esgoto doméstico, entretanto, como é complexo verificar se as fossas foram bem implementadas, somente foi considerada a rede geral na construção do índice de saneamento básico. O despejo do esgoto diretamente em rios, mares, lagos, valas representam riscos ambientais e para a população de um modo geral.

As variáveis trabalhadas para a construção desse índice foram expressas acima. Os dados sobre abastecimento de água, esgotamento rede geral e coleta de lixo foram extraídos do Censo Demográfico 2000, IBGE, que os disponibiliza por setor censitário.

O Distrito de Cachoeirinha apresentou bons resultados com relação à cidade de São Paulo. O abastecimento de água pela rede geral no distrito atinge no mínimo o índice de $92,8 \%$ dos domicílios e ainda apresenta uma distribuição homogênea. A cidade de São Paulo também apresenta bons índices, o que confirma os dados divulgados pela SABESP. O mínimo valor apresentado para a cidade como um todo é $0,25 \%$ e sua distribuição aparece mais concentrada nas regiões periféricas, tais como Marsilac, Perus, Anhanguera e Tremembé. Porém, o mesmo não é observado no distrito da Cachoeirinha que apesar de estar localizado em uma região periférica, apresenta bons índices, conforme apresentado nas figuras a seguir: 
Figura 9: Comparação entre os índices de abastecimento de água na Cachoeirinha e na Cidade de São Paulo.
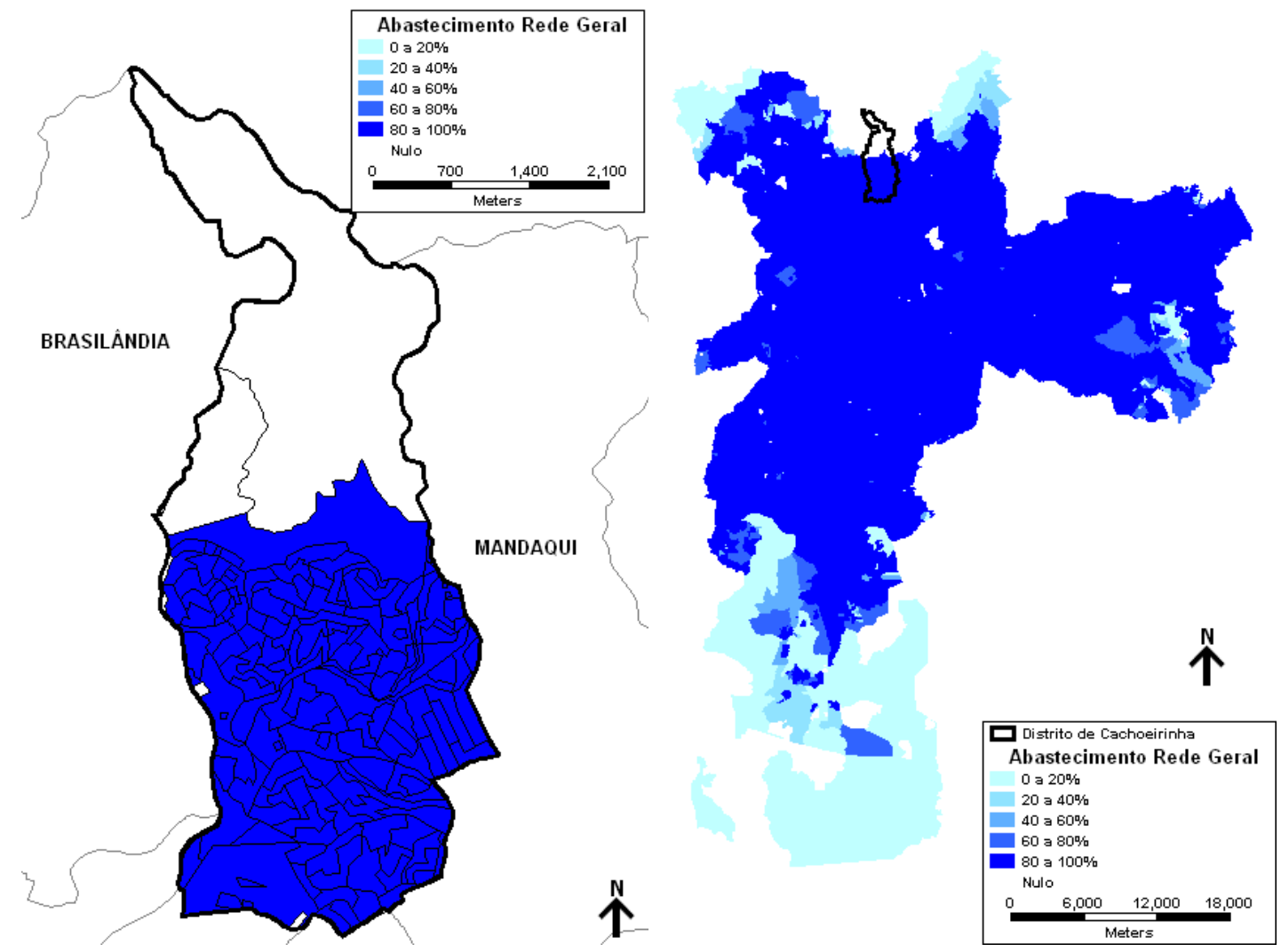

Fonte Censo Demográfico 2000, IBGE.

Como a proporção de abastecimento de água pela rede geral em pelo menos um cômodo resultou em um mapa semelhante, não serão representados novamente os valores.

Com relação ao esgotamento sanitário, o distrito apresenta bons índices, entretanto, os valores mínimos observados se aproximam de 0\% para alguns setores, localizados principalmente nas áreas próximas do parque Estadual da Cantareira e em áreas onde foram localizadas as favelas. Na cidade de São Paulo, os índices novamente são altos e se aproximam muito dos valores observados no índice anterior referente ao abastecimento: 
Figura 10: Comparação entre os índices de esgotamento sanitário na Cachoeirinha e na Cidade de São Paulo.
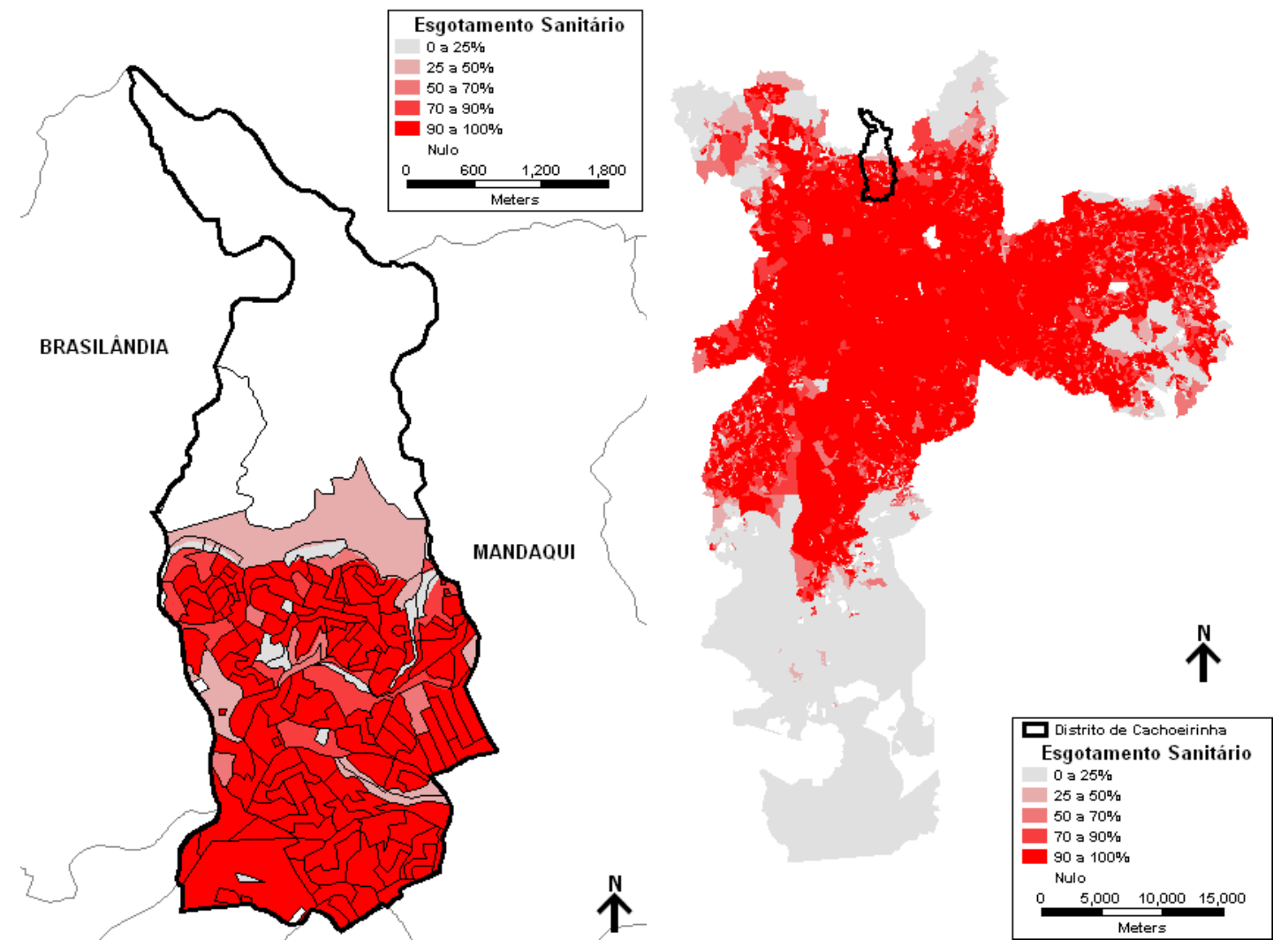

Fonte: Censo Demográfico 2000, IBGE.

A coleta de lixo apresenta índices elevados em todo o distrito de Cachoeirinha, apenas um setor, onde se localiza a favela Sucupira II é que foi possível verificar o menor índice de coleta de lixo, beirando o 0\%. Na cidade de São Paulo, os índices também são elevados, as regiões periféricas novamente são as mais prejudicadas, mas mesmo assim estas se encontram em melhores condições se comparadas aos indicadores de abastecimento e esgotamento sanitário, conforme mostram as figuras a seguir: 
Figura 11: Comparação entre os índices de coleta de lixo na Cachoeirinha e na Cidade de São Paulo.
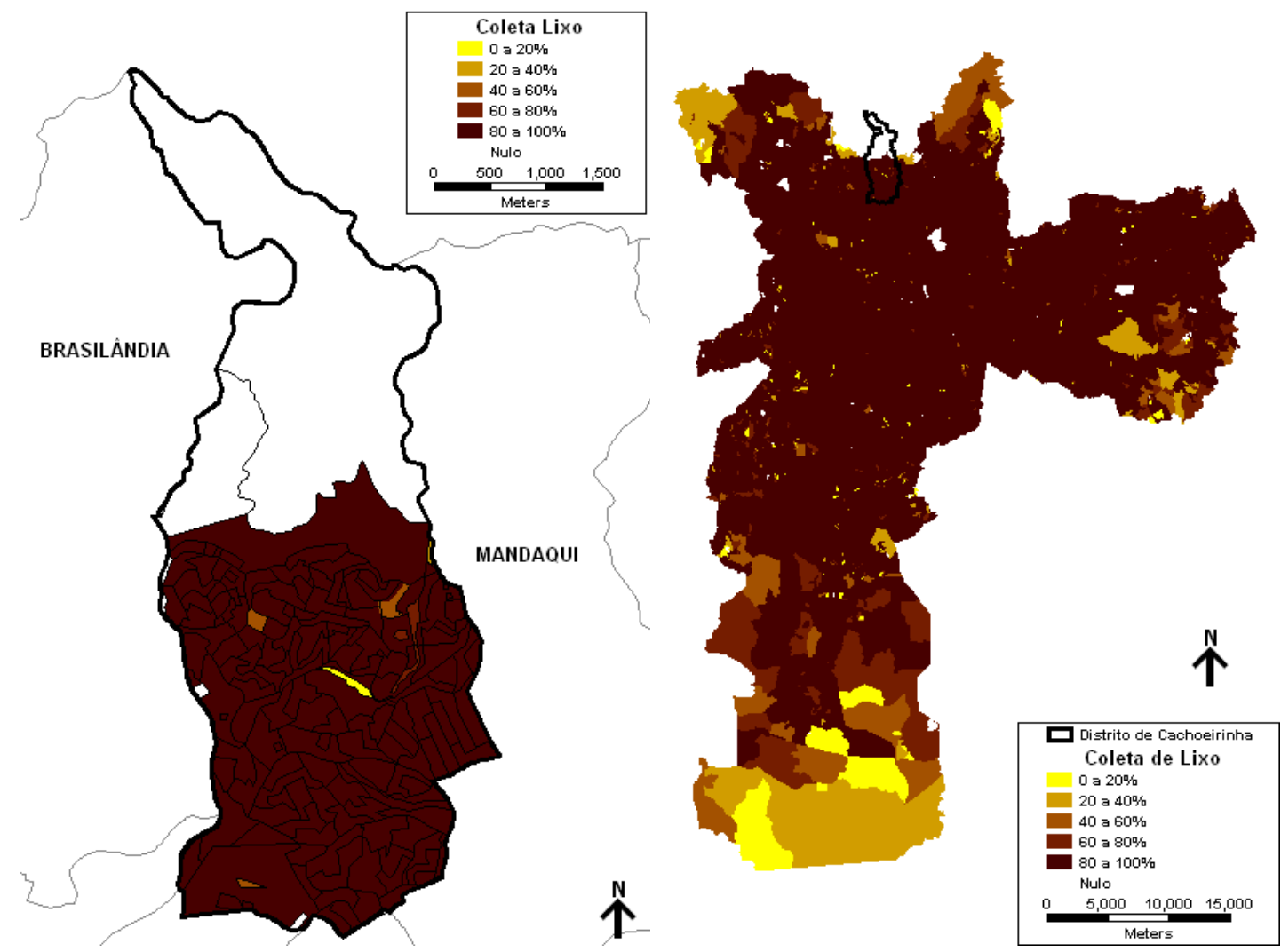

Fonte: Censo Demográfico 2000, IBGE.

\subsubsection{CONDIÇÕES SOCIOECONÔMICAS}

As condições socioeconômicas dizem respeito às situações materiais da população, ao acesso a bens e serviços necessários para a sobrevivência com dignidade.

Um padrão que pode ser considerado digno deve unir: moradia adequada, alimentação, vestuário e transporte, todos garantidos a partir de uma renda condizente com as necessidades básicas listadas acima. A variáveis selecionadas para se obter esse indicador estão relacionadas à renda e ao nível de escolaridade do responsável pelo domicílio.

A renda é uma variável importante para a avaliação do nível socioeconômico, porém não é única, tanto, que nos anos 90 com a criação do IDH, o PIB per capita dos países deixou de ser a melhor opção para se avaliar as condições de vida de uma população. A renda é sinônimo de valor recebido como resultado de atividade produtiva individual ou coletiva. 
Ao tratarmos dos rendimentos das pessoas, outros conceitos interligados surgem, como é o caso da pobreza e da desigualdade. A pobreza é um conceito de complexa mensuração ${ }^{4}$. De acordo com Marques (2005), a forma mais comum de enfrentar o problema é por meio da adoção de uma linha de pobreza. Essa adoção refere-se a uma questão metodológica e analítica, pois permite a realização de amplas comparações. As linhas de pobreza podem ser definidas por meio de valores absolutos ou relativos. Geralmente, as absolutas são as mais utilizadas e expressam os valores mínimos de rendimento necessários para a sobrevivência de uma família. Os valores relativos refletem uma noção mais ampla de pobreza e estão associados a políticas públicas específicas, também podem estar relacionados às definições nacionais ou regionais, que visam elucidar as variações de custo de vida em diferentes localidades.

Alguns estudos sociológicos tentam captar as diversas facetas da pobreza, que alegam não serem capturadas pelas linhas de pobreza. O grande problema é que a pobreza não pode ser definida como o mínimo necessário para a sobrevivência, pois mesmo as pessoas que conseguem sobreviver acima desse mínimo, não possuem acesso à educação, saneamento básico, saúde, cultura e integração social, que são os grandes benefícios das sociedades urbanas modernas. (Marques, 2005)

Portanto, a grande discussão acerca do calculo da linha de pobreza, pode ser resumida na seguinte questão: qual é o valor mínimo para garantir a sobrevivência?

Certamente o salário mínimo atual, próximo de quinhentos reais não cumpre o papel de garantir o mínimo de renda para a sobrevivência de uma família, mas vale à pena atentar também para o fato de que outros componentes, além do salário, influenciam no bem-estar social das famílias. Investimentos em educação e saúde, bem como em infra-estrutura básica, melhoram o bem-estar da população sem que se manifestem no poder de compra dos salários.

Quanto à renda, a medida mais adequada de se medi-la quando relacionadas aos estudos de pobreza é através da renda familiar per capita, que é a renda da família dividida pelo número de familiares. Entretanto, como este

\footnotetext{
${ }^{4}$ Para se compreender melhor o conceito de pobreza ler capítulo 1 do livro Segregação, Pobreza e Desigualdades sociais indicado na bibliografia. Nele o autor discute conceitos, definições de linha de pobreza por meio da ótica sociológica.
} 
estudo visa compreender e mensurar a qualidade de vida do distrito de Cachoeirinha e não a pobreza propriamente dita preferiu-se trabalhar com o rendimento nominal médio do responsável pelo domicílio, conforme mapa abaixo:

Figura 12: Comparação entre a renda média do chefe de família na Cachoeirinha e na Cidade de São Paulo.
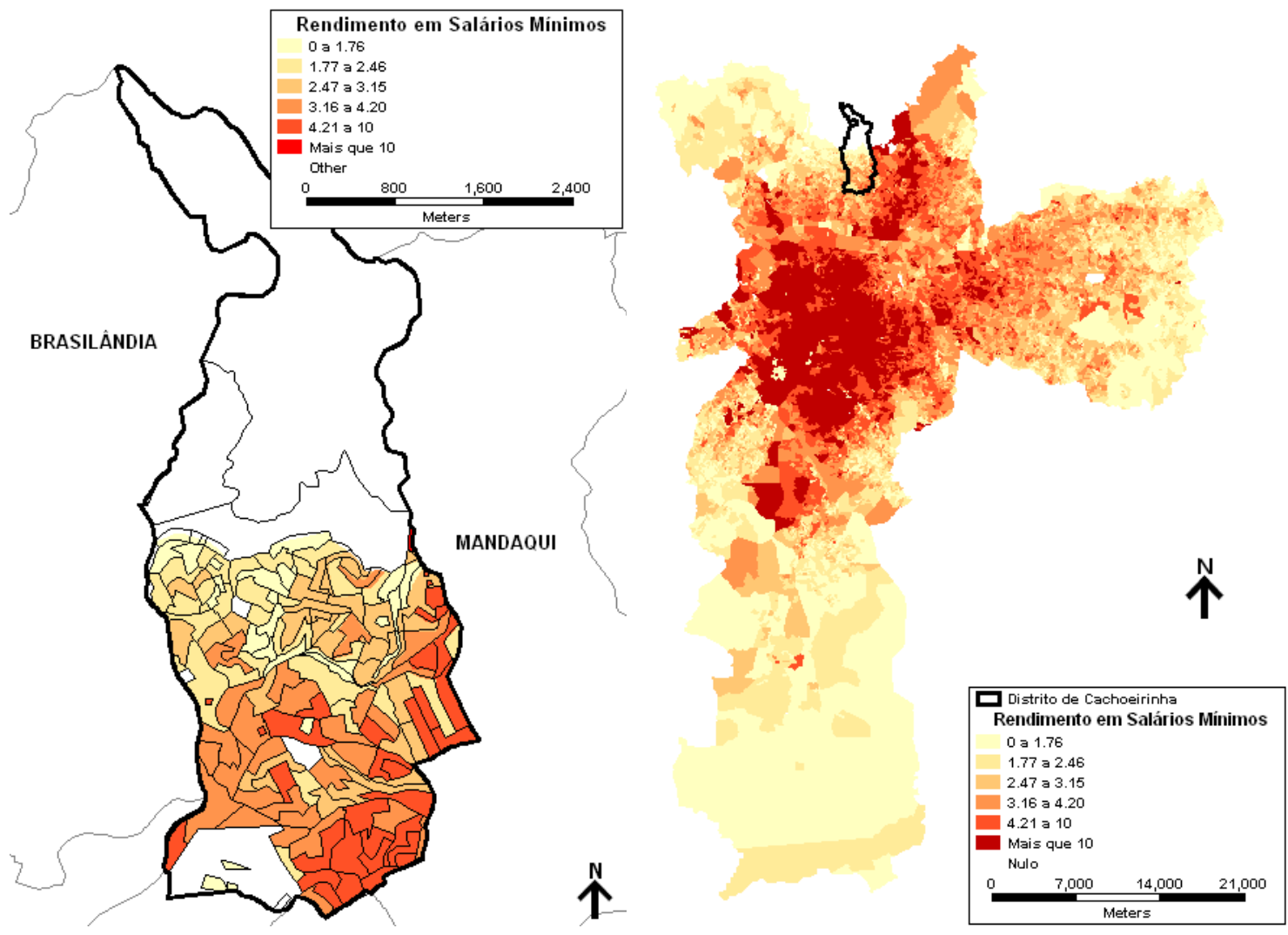

Fonte: Censo Demográfico 2000, IBGE.

É possível observar na Cachoeirinha um padrão de renda melhor na parcela sul-sudeste do distrito do que na norte-noroeste. Essa observação também pode ser feita por meio das zonas residenciais homogêneas, onde se nota um padrão construtivo melhor na parte sul e urbana do distrito de Cachoeirinha, denotando-se melhor renda. E um padrão pior na parte norte e urbana, onde se encontram também a maior parte das favelas do distrito. Com relação à cidade como um todo, é na periferia que se concentram os chefes de família que recebem de zero a quase três salário mínimos. As áreas centrais concentram os chefes que recebem bem mais, podendo chegar a quase 100 (cem) salários mínimos. Nesse caso, o distrito de Cachoeirinha apresenta um 
padrão de distribuição de renda dos chefes que se assemelha ao da cidade de São Paulo, ou seja, os responsáveis pelos domicílios que recebem menos se concentram nas mais áreas periféricas.

Com relação à escolaridade, novamente o levantamento foi efetuado considerando o nível educacional dos chefes de família, a figura abaixo representa a porcentagem de chefes alfabetizados no distrito e sua comparação com os índices da cidade.

Figura 13: Comparação entre o índice dos chefes de família alfabetizados na Cachoeirinha e na Cidade de São Paulo.

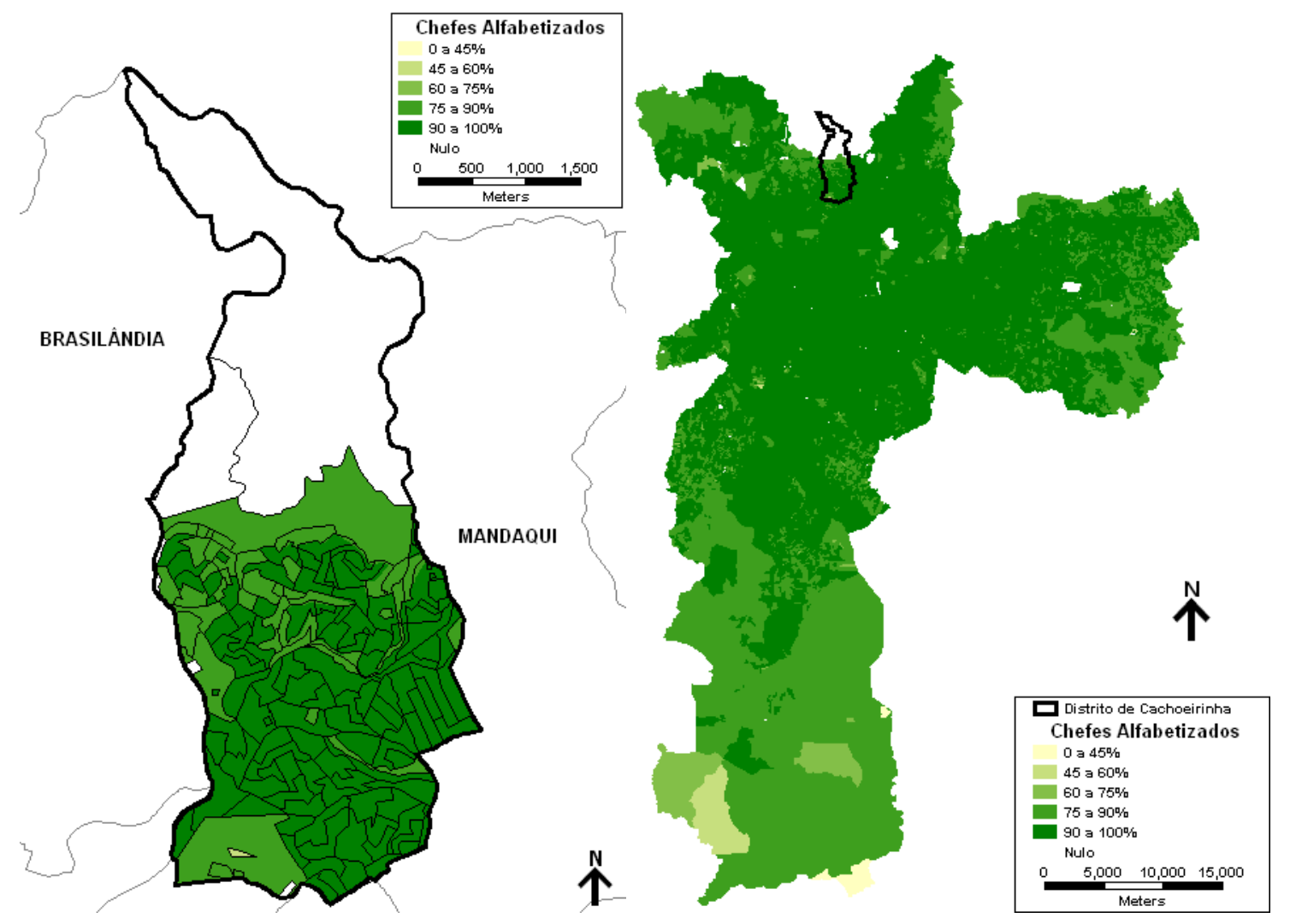

Fonte: Censo Demográfico 2000, IBGE.

Enquanto no distrito de Cachoeirinha os valores mínimos observados giram entorno de 55\% de chefes alfabetizados, na cidade como um todo, as porcentagens são elevadas, sendo que apenas um setor apresenta índice de 33\%, e está localizado no distrito de Marsilac.

Outro índice relevante para a análise da qualidade de vida na Cachoeirinha foi a quantidade de chefes de família com o ensino fundamental completo. Normalmente a renda e a escolaridade são fatores de extrema importância na 
caracterização da população e ambas são consagradas em diversos estudos acerca da qualidade de vida por serem altamente relacionáveis.

Figura 14: Comparação entre os índices dos chefes de família com ensino fundamental completo na Cachoeirinha e na Cidade de São Paulo.
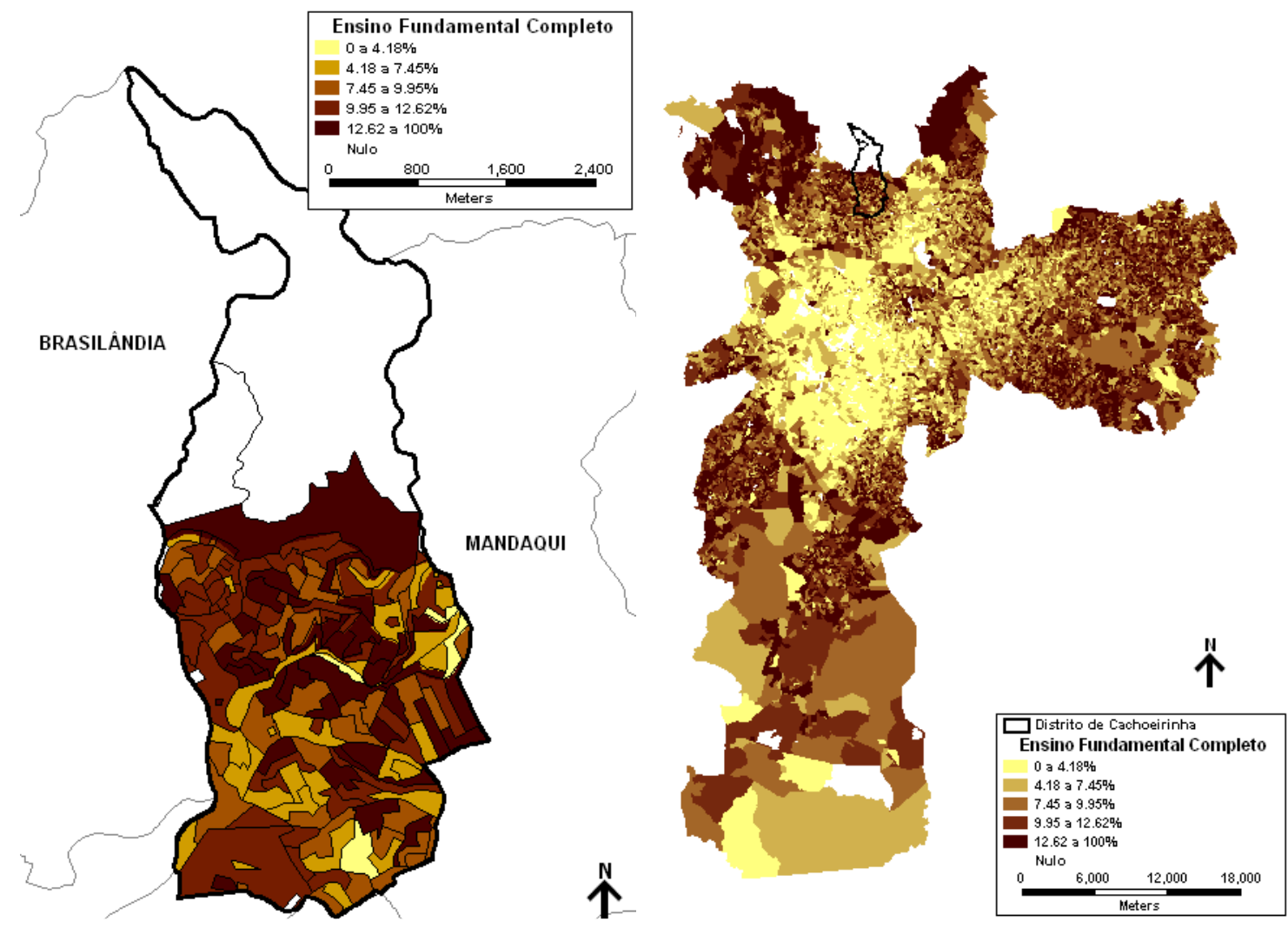

Fonte: Censo Demográfico 2000, IBGE.

É possível observarmos que no mapa da cidade os setores mais centrais, onde a renda é mais elevada, existe menor quantidade de chefes de família apenas com o ensino fundamental completo. No distrito de Cachoeirinha, existe uma distribuição que não é homogênea, mas que reflete a situação das áreas periféricas da cidade, as quais concentram a maior parte dos chefes de família apenas com o ensino fundamental completo. 


\section{CAPÍTULO 5}

\section{MATERIAIS E MÉTODOS}

Segue abaixo a lista de materiais utilizados na presente pesquisa:

- Imagem Digital IKONOS no modo colorido RGB bandas Red, Green, Blue, com 4 metros de resolução espacial. Adquiridas em maio de 2007 por meio do Laboratório de Sensoriamento Remoto do Departamento de Geografia da Faculdade de Filosofia, Letras e Ciências Humanas da Universidade de São Paulo.

- Malha vetorizada das favelas da cidade de São Paulo elaborada pelo Centro de Estudos da Metrópole no ano 2000.

- Malha vetorizada dos setores censitários IBGE 2000. Disponibilizado pelo Centro de estudos da Metrópole no ano 2003.

- Maptitude 4.6 (Caliper) - Sistema de Informações Geográficas, ambiente utilizado para juntar as bases de dados processadas no software SPSS 13, bem como elaboração de mapas temáticos de localização da área de estudo e comparação entre indicadores.

- ArcGis 9.2 - Sistema de Informações Geográficas utilizados para elaboração dos mapas temáticos de qualidade de vida e zonas residenciais homogêneas do presente trabalho.

- SPSS 13 - software utilizado para a elaboração das análises estatísticas. Esse programa é um pacote estatístico elaborado para as Ciências Sociais. No SPSS foram elaboradas as análises multivariadas citadas no presente estudo (Fatorial e Agrupamento) 


\subsection{METODOLOGIA}

Conforme exposto até o momento, foi possível notar que apesar das diversas abordagens e significados variados que o conceito de qualidade de vida pode assumir em sua mensuração, os trabalhos citados e suas respectivas metodologias utilizam preponderantemente dados que dizem respeito a aspectos objetivos e coletivos da sociedade. Seria muito mais complexo trabalhar com questões relacionadas às satisfações pessoais, que fugiria do escopo do presente trabalho. Uma série de fatores influenciou na escolha das variáveis para compor os indicadores que culminaram na síntese da qualidade de vida, tais como, facilidade de acesso aos dados, escala de estudo, qualidade dos dados, e a padronização.

A tabela abaixo demonstra metodologias consagradas e que foram utilizadas para fins de mapeamento da qualidade de vida e construção de indicadores afins. A dimensão renda é utilizada como indicador em todos os estudos expostos, os autores em destaque foram pesquisados e utilizados como referência para a elaboração deste estudo.

Tabela 2: Metodologias e seus respectivos indicadores voltados ao mapeamento da Qualidade de Vida

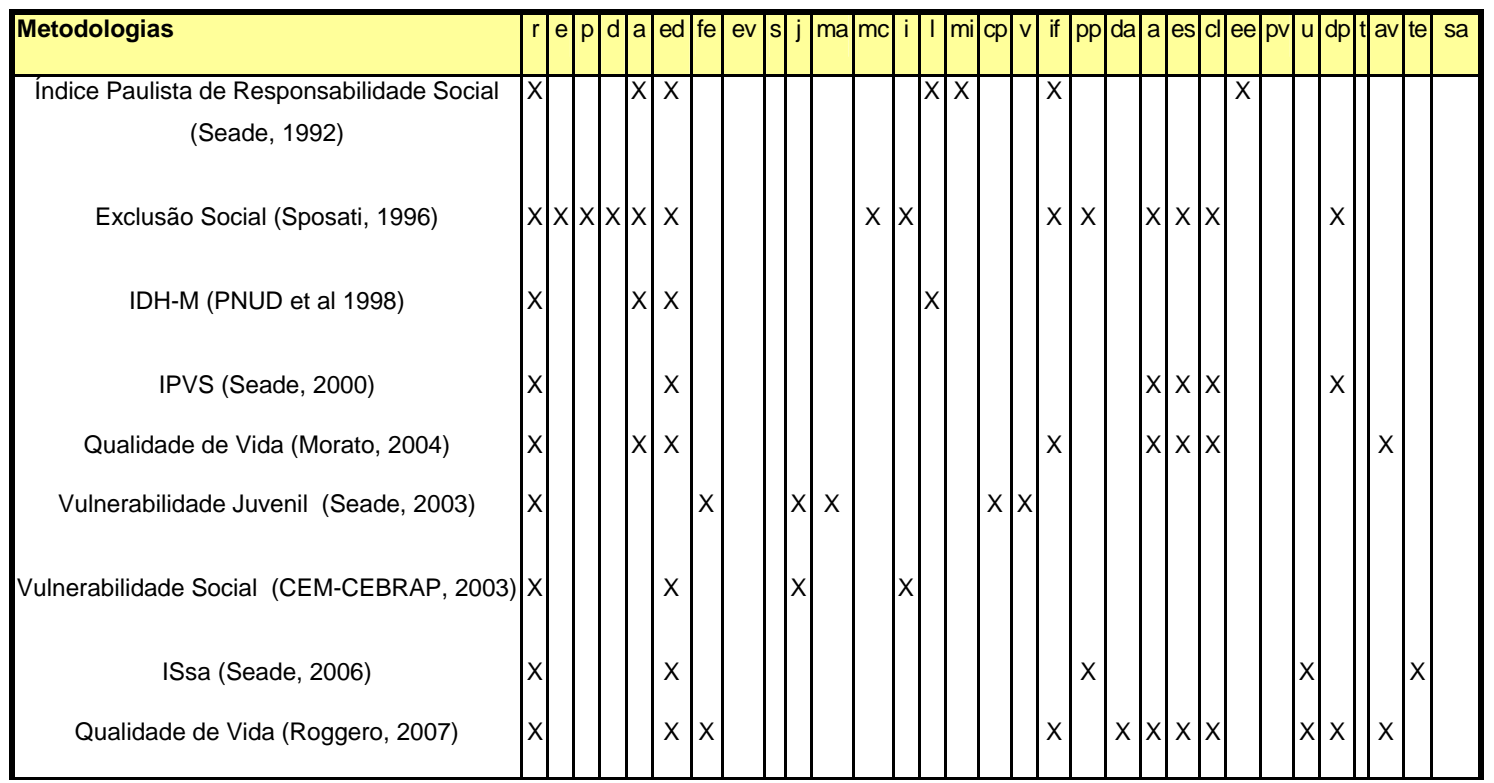

Legenda - r: renda; e: emprego; p: pobreza; d: desigualdade social; a: alfabetização; ed: escolaridade; fe: freqüência à escola; ev: evasão escolar; s: saúde; j: presença de jovens; ma: mães adolescentes; mc: mulheres chefes de família; i: presença de idosos; I: longevidade; mi: mortalidade infantil; cp: crescimento populacional; v: violência; if: infra-estrutura urbana; pp: propriedade domiciliar; da: domicílios alugados; a: abastecimento de água; es: destino do esgoto; cl: coleta de lixo; ee: energia elétrica; pv: pavimentação; u: classe de uso da terra nas áreas vizinhas; dp: densidade da população; t: tamanho da residência; av: áreas verdes; te: temperatura; sa: grau de satisfação da população

Fonte:LUCHIARI, KAUAKUBO, MORATO, MARTINES \& FERREIRA A. \& F. S. \& R. G. \& M. R. \& R. V Mapeamento da Qualidade de vida Urbana no Município de Osasco/SP. Artigo apresentado no III Encontro da Associação Nacional de Pós Graduação e Pesquisa em Ambiente e Sociedade - Maio, 2006. Adaptado pela autora. 
Com relação às metodologias apresentadas acima, Morato (2004) atribuiu pesos diferentes para as variáveis utlizadas, algo que não se pretendeu no presente estudo, pois se considerou todas as variáveis de extrema importância para o mapa índice final. Sendo decidido por meio de análises multivariadas quais seriam viáveis para o estudo. Outro fator que pode influenciar nos resultados obtidos por meio da utilização dos dados censitários, é o fato de se ter utillizado ou não apenas os domicílios permanentes considerados no censo demográfico. Pois, torna-se bastante complicado o uso de variáveis que podem ser temporárias e não refletirem a situação demográfica da unidade de análise escolhida, como o setor censitário.

No caso do ISsa, também apresentado no capítulo 3.2.2, o índice contou com os dados oriundos de bases vetoriais, sendo os setores censitários imputados com os dados do IPVS e informações do Atlas Ambiental do Município de São Paulo.

O presente estudo contou com dados provenientes dos setores censitários 2000 e dados e de informações extraídas de imagens raster, transformadas em dados vetoriais por meio da fotointerpretação e posterior classificação das zonas residenciais homogêneas. Nessa pesquisa também foram selecionadas variáveis que aliassem a qualidade ambiental à situação socioeconômica e a infra-estrutura urbana. Essa seleção foi baseada nos critérios das necessidades básicas, que corresponde ao mínimo dos serviços e condições ambientais para que a população tenha uma vida saudável. Apesar desse enfoque, como foi explicitado no capítulo 3.1.5, estabelecer incentivos para se atingir o pleno desenvolvimento físico, mental e social, essa linha de pensamento deixa imprecisões a respeito de quais são essas necessidades e de como elas podem variar individualmente.

$\mathrm{Na}$ tabela a seguir encontram-se as variáveis pré-selecionadas do Censo Demográfico 2000, IBGE para a construção do mapa síntese da qualidade de vida. 
Tabela 3: Indicadores construídos a partir de variáveis do censo demográfico.

\begin{tabular}{|c|c|}
\hline $\begin{array}{l}\text { condições } \\
\text { de Habitação } \\
\text { (Porcentagem) }\end{array}$ & $\begin{array}{l}\text { Domicílios particulares permanentes } \\
\text { Domicílios particulares permanentes - tipo - cômodo } \\
\text { Domicílios particulares permanentes - condição de ocupação - próprio -quitado } \\
\text { Domicílios particulares permanentes - condição de ocupação - alugado } \\
\text { Domicílios particulares permanentes - sem banheiro ou sanitário }\end{array}$ \\
\hline $\begin{array}{l}\text { condições } \\
\text { de Saneamento } \\
\text { (Porcentagem) }\end{array}$ & $\begin{array}{l}\text { Domicílios particulares permanentes - abastecimento de água - rede geral } \\
\text { Domicílios particulares permanentes - abastecimento de água - rede geral - } \\
\text { canalizada em pelo menos um cômodo } \\
\text { Domicílios particulares permanentes - com banheiro ou sanitário - esgotamento sanitário - } \\
\text { rede geral de esgoto ou pluvial } \\
\text { Domicílios particulares permanentes - destino do lixo - coletado por serviço de limpeza }\end{array}$ \\
\hline $\begin{array}{l}\text { Renda } \\
\text { (Em Salários } \\
\text { Mínimos) }\end{array}$ & $\begin{array}{l}\text { Pessoas responsáveis pelos domicílios particulares permanentes } \\
\text { Rendimento nominal mensal - pessoas responsáveis pelos domicílios particulares permanentes } \\
\text { Pessoas responsáveis pelos domicílios particulares permanentes - } \\
\text { rendimento nominal mensal - até } 1 \text { /2 salário mínimo } \\
\text { Pessoas responsáveis pelos domicílios particulares permanentes - } \\
\text { rendimento nominal mensal - mais de } 1 / 2 \text { a } 1 \text { salário mínimo } \\
\text { Pessoas responsáveis pelos domicílios particulares permanentes - } \\
\text { rendimento nominal mensal - mais de } 1 \text { a } 2 \text { salários mínimos } \\
\text { Pessoas responsáveis pelos domicílios particulares permanentes - } \\
\text { rendimento nominal mensal - mais de } 2 \text { a } 3 \text { salários mínimos }\end{array}$ \\
\hline $\begin{array}{l}\text { Características } \\
\text { Demográficas } \\
\text { (Porcentagem) }\end{array}$ & $\begin{array}{l}\text { Pessoas responsáveis pelos domicílios particulares permanentes - } 10 \text { a } 19 \text { anos de idade } \\
\text { Pessoas responsáveis pelos domicílios particulares permanentes - } 20 \text { a } 29 \text { anos de idade } \\
\text { Pessoas responsáveis pelos domicílios particulares permanentes - } 30 \text { a } 39 \text { anos de idade } \\
\text { Pessoas responsáveis pelos domicílios particulares permanentes - } 40 \text { a } 49 \text { anos de idade } \\
\text { Pessoas responsáveis pelos domicílios particulares permanentes - } 50 \text { a } 59 \text { anos de idade } \\
\text { Pessoas responsáveis pelos domicílios particulares permanentes - } 60 \text { a } 69 \text { anos de idade } \\
\text { Pessoas responsáveis pelos domicílios particulares permanentes - } 70 \text { a } 79 \text { anos de idade } \\
\text { Pessoas responsáveis pelos domicílios particulares permanentes - } 80 \text { anos de idade ou mais } \\
\text { Pessoas residentes - } 0 \text { anos de idade } \\
\text { Pessoas residentes - } 1 \text { anos de idade } \\
\text { Pessoas residentes - } 2 \text { anos de idade } \\
\text { Pessoas residentes - } 3 \text { anos de idade } \\
\text { Pessoas residentes }-4 \text { anos de idade }\end{array}$ \\
\hline $\begin{array}{c}\text { Educação } \\
\text { (Porcentagem) }\end{array}$ & $\begin{array}{l}\text { Pessoas responsáveis pelos domicílios particulares permanentes - alfabetizadas } \\
\text { Pessoas responsáveis pelos domicílios particulares permanentes - série concluída com aprovação } \\
\text { oitava série - ensino fundamental ou primeiro grau } \\
\text { Anos de estudo - pessoas responsáveis pelos domicílios particulares permanentes }\end{array}$ \\
\hline
\end{tabular}

Fonte: Censo demográfico IBGE, 2000.

A construção desses indicadores foi baseada outros estudos realizados e já destacados em capítulos anteriores como o IPVS (Seade, 2000) e Vulnerabilidade Social (Cem-Cebrap, 2003). Essa seleção permite a identificação e utilização de indicadores já consagrados em outras pesquisas, minimizando deste modo às arbitrariedades.

No estudo foram utilizados os 157 setores censitários (IBGE, 2000) pertencentes ao distrito de Cachoeirinha. Os indicadores relacionados à habitação e saneamento foram elaborados de acordo com a quantidade de domicílios particulares permanentes, pois, todas as demais variáveis selecionadas para compor esses indicadores são referentes a essa variável específica. 
A variável referente ao esgotamento sanitário - fossa séptica foi excluída da construção do indicador de saneamento básico, devido às imprecisões sobre as técnicas construtivas, pois uma fossa mal implantada pode trazer sérias conseqüências para o meio ambiente e afetar a qualidade de vida de uma comunidade.

Feitas as considerações acima, podemos iniciar a descrição das etapas de trabalho. A primeira etapa da construção dos indicadores constituiu-se da importação dos dados do censo demográfico 2000 em formato dbase ( ${ }^{*} \mathrm{dbf}$ ) para o formato *sav correspondente ao software SPSS 13. O SPSS Data Editor é útil para fazer testes estatísticos, tais como os testes da correlação, multicolinearidade, e de hipóteses; e também pode propiciar ao pesquisador contagens de freqüência, ordenar dados e reorganizar a informação.

As primeiras estatísticas realizadas nesta etapa foram as descritivas, de onde foram extraídas as médias, os valores máximos e mínimos respectivamente e o desvio padrão. As freqüências extraídas das variáveis e dos indicadores foram indispensáveis para localizar os valores nulos e a porcentagem dos dados trabalhados.

Como o distrito de Cachoeirinha faz parte de um universo maior, que é a cidade de São Paulo, sentiu-se a necessidade de efetuar a comparação dos dados dos setores censitários deste distrito com o restante do município.

\subsection{ANÁLISE FATORIAL}

É uma análise multivariada que se aplica à busca de identificação de fatores num conjunto de dados. A redução da dimensionalidade, além do procedimento de processamento de dados para a condução de análises multivariadas, é objeto específico da análise fatorial e da análise de correspondência. (Pereira, 2001)

Para a criação de um índice sintético de qualidade de vida, primeiramente foi realizada a análise fatorial com base em variáveis da amostra do Censo 
Demográfico 2000, IBGE ${ }^{5}$ selecionadas por apresentarem boa interdependência entre si e com os parâmetros propostos para se medir a qualidade de vida.

As variáveis consideradas estão relacionadas a seguir:

Tabela 4: Indicadores selecionados para a análise fatorial.

\begin{tabular}{|c|l|}
\hline $\begin{array}{c}\text { Condições } \\
\text { de Saneamento }\end{array}$ & $\begin{array}{l}\text { Domicílios particulares permanentes - abastecimento de água - rede geral (\%) } \\
\text { Domićlios particulares permanentes - abastecimento de água - rede geral - } \\
\text { canalizada em pelo menos um cômodo (\%) } \\
\text { Domicílios particulares permanentes - com banheiro ou sanitário - esgotamento sanitário - } \\
\text { rede geral de esgoto ou pluvial (\%) } \\
\text { Domicílios particulares permanentes - destino do lixo - coletado por serviço de limpeza (\%) }\end{array}$ \\
\hline Situação & $\begin{array}{l}\text { Rendimento nominal médio do responsável pelo domicílio (em Salários Mínimos) } \\
\text { Pessoas responsáveis pelos domicílios particulares permanentes - alfabetizadas (\%) } \\
\text { Pessoas responsáveis pelos domicílios particulares permanentes - série concluída com aprovação } \\
\text { oitava série - ensino fundamental ou primeiro grau (\%) } \\
\text { Anos de estudo - pessoas responsáveis pelos domicílios particulares permanentes }\end{array}$ \\
\hline Demografia & $\begin{array}{l}\text { Proporção de crianças de 0 a } 4 \text { anos por setor (\%) } \\
\text { Número médio de habitantes por domicílio }\end{array}$ \\
\hline
\end{tabular}

Fonte: Censo Demográfico IBGE, 2000.

Esses indicadores foram mantidos na amostra, os demais foram excluídos após vários testes, pois dessa forma procurou-se obter os indicadores mais expressivos para cada conjunto, pois, se todos os indicadores expressos na tabela 3 fossem utilizados a análise fatorial teria sido inviabilizada.

Nesse sentido, o índice sintético criado relacionou as três dimensões expostas acima, condições de saneamento, situação socioeconômica e demografia, sendo inserido o número médio de habitantes por domicílio.

A identificação de novas dimensões na análise fatorial foi realizada através do método das componentes principais. Esse não é o único e há alternativas que podem ser consideradas (Maximum likehood, Alpha factoring...).

\subsubsection{ANÁLISE DE AGRUPAMENTO (CLUSTERS ANALYSIS)}

É outro tipo de análise multivariada. Nessa análise as distâncias entre os objetos estudados dentro do espaço multpiplano constituído por eixos de todas as

5 O Censo é baseado em dois questionários um sucinto, denominado questionário para o universo do censo, que abrange toda a população; e outro mais abrangente e detalhado que é aplicado em uma amostra que corresponde a $10 \%$ dos domicílios. 
variáveis são calculadas e a seguir os objetos são agrupados de acordo com as proximidades entre eles. (Pereira, 2001)

A análise do tipo cluster pode ser sintetizada de acordo com os seguintes procedimentos:

- Primeiro se realiza o cálculo das distâncias euclidianas entre os objetos estudados no espaço multiplano de todas as variáveis consideradas.

- Seqüência de agrupamento por ordem geométrica

- Reconhecimento dos passos de agrupamento para a identificação coerente de grupos dentro do universo de objetos estudados. (Pereira, 2001)

\subsection{INTERPRETAÇÃO VISUAL DAS IMAGENS IKONOS}

O mapa de uso do solo foi elaborado por meio de técnicas de interpretação visual de imagens de satélite IKONOS (2002) composição colorida bandas 3, 2, 1 , associando-se às cores vermelho $(R)$, verde $(G)$ e azul $(B)$. Para isso, utilizou-se a metodologia consolidada de interpretação visual de fotografias aéreas tendo em vista o grau de detalhamento das informações contidas no produto.

A interpretação de imagens enquanto envolve três etapas distintas: a leitura ou reconhecimento, a análise e a fotointerpretação. (Souza, 2004)

A leitura ou reconhecimento enquanto método consiste na interpretação preliminar, um reconhecimento inicial de feições presentes nas imagens. A leitura exige conhecimento técnico e experiência do intérprete. É nesta etapa que as feições e os objetos são identificados e ordenados de acordo com o contexto inserido.

A etapa final é a fotointerpretação propriamente dita, esta é a fase em que a interpretação exige os raciocínios lógicos, dedutivo e indutivo do intérprete para explicar objetos identificados nas etapas anteriores.

Segundo Novo (1992), o processo de interpretação visual de imagens baseia-se em certos princípios de análises, métodos para identificar e medir objetos observados a partir de uma perspectiva aérea e orbital. Para a autora a interpretação visual das imagens de satélite é feita a partir dos elementos de análise da imagem. Estes elementos são:

- Forma: pode ser utilizada para identificar feições individuais. Estas podem ser irregulares ou geométricas. Geralmente as feições naturais, tais como uma 
Mata nativa, possuem formas irregulares, já as feições construídas pelo homem possuem formas geométricas regulares, como culturas, edifícios etc.

- Tamanho: esta característica está relacionada à escala e a resolução espacial da fonte de dados. O tamanho da feição pode indicar o tipo de ocupação, por exemplo. As imagens de alta resolução espacial, utilizadas neste trabalho, permitiram o reconhecimento deste elemento que foi de grande importância para a definição das zonas residenciais.

- Cor: em imagens coloridas os objetos podem ser diferenciados através da variação deste elemento. Em imagens pretas e brancas as diferenciações são feitas através das variações nos tons de cinza. A vantagem é que o olho humano é capaz de distinguir mais cores do que tons de cinza.

- Textura: é produzida pela agregação de unidades muito pequenas para serem analisadas em conjunto, tendo em vista a dificuldade de analisá-las individualmente. Segundo Pavão (2005), a textura oferece padrão visual de rugosidade de determinada porção da imagem, consituindo-se um elemento fundamental para a identificação de objetos.

- Padrão: este elemento está relacionado ao arranjo espacial dos objetos. A repetição de certas formas e seus relacionamentos estabelece padrões que auxiliam a fotointerpretação. Certos padrões são facilmente reconhecidos, tal como o padrão retilíneo dos sistemas viários das cidades.

Após a finalização das etapas descritas acima, foi realizado trabalho de campo para pesquisa e levantamento de dúvidas. Feito isso, procedeu-se à correção de polígonos da fotointerpretação e obteve-se o mapa final de Uso do Solo e Cobertura Vegetal (2002).

\subsubsection{ELABORAÇÃO DE CHAVES DE INTERPRETAÇÃO}

A chave de interpretação consiste na descrição do conjunto de elementos verificados na fotointerpretação, de modo a caracterizar o alvo da superfície terrestre. Um dos tipos mais comuns das chaves de interpretação é o que apresenta uma descrição dos objetos de acordo com sua aparência e ocorrência no terreno. 
Devido à importância das áreas residenciais para a realização da presente pesquisa, deu-se um enfoque maior nas zonas residenciais, de onde foram reconhecidas as seguintes categorias:

- Cemitério - Geralmente é considerada como área institucional, entretanto, devido à escala de trabalho, essa área é facilmente identificada na imagem e apresenta textura bastante rugosa, forma e tamanho que o diferenciam dos demais alvos.

- Solo Exposto - São áreas claras, onde se é possível detectar a remoção da vegetação e possui uma cor bege bem característica. Geralmente essa categoria representa os terrenos vagos na cidade ou algum empreendimento em implantação.

- Campo de Futebol - Nesse distrito a ocupação para fins residênciais é muito grande, os campos de futebol aparecem próximos às favelas e conjuntos habitacionais.

- Conjunto Habitacional Vertical - Essas áreas são bastante distinguíveis na área de estudo devido ao padrão dos edifícios, geralmente todos seguem o mesmo padrão construtivo, tamanho das edificações e dos lotes. A textura é bastante variada e diferenciada de acordo com o tipo, tamanho e outras variáveis associadas. Nas zonas residenciais essa chave será analisada mais detalhadamente.

- Capoeira - São áreas verdes que foram desmatadas e apresentam apenas algumas árvores de baixo porte e grama. São representados por algumas áreas públicas ou terrenos vagos.

- Mata - É a mata preservada que se encontra no parque estadual da Cantareira ao norte da área de estudo.

- Favelas - São áreas onde se localizam as residências mais precárias do distrito. Possuem uma textura rugosa, onde dificilmente se verifica o tamanho do lote, as ruas também possuem um traçado irregular. As casas possuem uma cobertura cinza ou acinzentada representada pelas telhas de amianto ou por lajes.

- Residências Horizontais - Essas áreas foram bem distinguidas na área de estudo. Presença de arruamento bem definidos, terrenos regulares, predominância da cor laranja no telhado, associada ao material cerâmico. 
A diferenciação mais detalhada desta área também será realizada no mapa das zonas residenciais homogêneas.

- Edifícios - Os edifícios foram identificados na imagem por meio da forma, tamanho e da sombra projetada na imagem.

- Galpão - Essas áreas são facilmente identificáveis na imagem, geralmente são edificações grandes e possuem telhados de alumínio que refletem bastante. Em alguns galpões é possível observar pátio de estacionamento. Esta classe foi mais discriminada pelos elementos forma e tamanho.

- Equipamento Urbano - Nesta categoria foram considerados shopping centers, terminal de ônibus, escolas, hospitais, igrejas e outras edificações que não entrariam em nenhuma das categorias anteriores. Muitas áreas pertencentes a esta classe foram identificadas por meio do conhecimento que o fotointerprete possui da área de estudo.

Tentou-se efetuar a classificação supervisionada dos usos da área de estudo, mas, por se tratar de uma área urbana densa, a confusão de pixels com as classes criadas foi grande, pois, o sofware confundiu piscinas com o telhado do terminal de ônibus e telhados dos galpões com lajes.

\subsubsection{DETERMINAÇÃO DAS ZONAS RESIDENCIAIS HOMOGÊNEAS}

Após a definição do mapa de uso do solo e consequentemente da chave de interpretação, foram delimitadas as zonas residenciais e caracterizada diferentes texturas para estas classes. Este procedimento foi executado no formato digital na tela do computador e verificado em campo, pois algumas variáveis não foram possíveis de serem detectadas na imagem.

A determinação das zonas residenciais homogêneas seguiu os mesmos parâmetros estabelecidos por Kurkdjian (1986) e Souza (2004), que adotaram uma metodologia de setorização residencial urbana, baseando-se na discriminação visual da textura de imagens e satélites IKONOS II e fotografias aéreas pancromáticas 1:10.000 respectivamente.

Dentre as variáveis físicas interpretadas nesta fase de análise, foram destacadas as consideradas abaixo e que são passíveis de verificação a partir dos produtos digitais utilizados. 
- Arborização de logradouros e lotes

Verificou-se presença de jardins e ruas arborizadas, geralmente preocupação vinculada à população com um bom poder aquisitivo.

- Tamanho e ocupação do Lote

Essas variáveis estão fortemente vinculadas à renda familiar, as disposições das construções e seus tipos, se possuem piscinas, tamanho dos telhados e tipos de telhados.

- Organização das quadras

Permite a diferenciação das áreas planejadas e regulamentadas daqueles onde a ocupação ocorreu ao longo dos anos sem planejamento e que possuem formas e tamanhos variados das construções residenciais.

\section{- Traçado e tratamento do sistema viário}

Permite a identificação de ruas mais largas, estreitas, se são pavimentadas ou não e também se os traçados são regulares.

\subsubsection{A ANÁLISE DE AGRUPAMENTO FINAL}

Após a elaboração da primeira análise estatística baseada nos dados do Censo Demográfico 2000 (IBGE) e da construção do mapa das zonas residenciais homogêneas, por meio de interpretação das imagens de satélites, elaborou-se uma classificação qualitativa dessas zonas. Essa classificação norteou o processo de fusão dos dados dos setores censitários e das zonas residenciais homogêneas.

Essa classificação foi baseada na divisão das zonas residenciais homogêneas em quatro classes, de acordo com as qualidades de cada zona conforme exposto abaixo:

- ZRH 4, ZRH 8, ZRH 9 - Boa

- ZRH 1, ZRH 2, ZRH 3, ZRH 6, ZRH 10 - Razoável

- ZRH 5 - Ruim

- FAVELA - Péssima 
Os dados classificados acima foram numerados para posteriormente serem processados:

- $\mathrm{BOA}-1$

- RAZOÁVEL - 2

- RUIM - 3

- PÉSSIMA - 4

No processo de imputação dos dados processados no software SPSS para o SIG, foram utilizadas ferramentas existentes no sistema que permitem a união de um banco de dados espaciais para outro por meio da função join, que permite a migração de dados processados fora do SIG, mas que contenha a mesma chave primária, no caso é numeração dos setores censitários.

Após a imputação dos dados no SIG e da classificação dos dados qualitativos, foi efetuada outra análise de agrupamento, visando agregar os dados obtidos via setores censitários e dados das zonas residenciais homogêneas agregadas. Para isso, foi utlizada a função overlay do SIG que trabalha essencialmente com a lógica da sobreposição de áreas. (SOUZA, 2006)

\section{CAPÍTULO 6}

\section{RESULTADOS}

De acordo com o mapa de Uso do Solo e Cobertura vegetal (2002), é possível observarmos a distribuição de favelas na porção urbana ao norte do distrito, acompanhado por alguns conjuntos habitacionais, bem próximos ao limite do parque estadual da Cantareira.

É conhecido o déficit habitacional da cidade de São Paulo de aproximadamente 800mil moradias e ao observarmos o mapa de uso do solo, é possível verificarmos que os conjuntos habitacionais e as favelas se localizam próximos. Geralmente em virtude de programas habitacionais, uma região tida como ilegal, se consolida a partir da construção de conjuntos de edifícios, que irá se beneficiar de uma série de obras de infra-estrutura, tais como: água, esgoto, 
asfaltamento. Esse processo atrai novos moradores para região, que sem terem para onde ir, constroem suas moradias no entorno desses conjuntos habitacionais.

O mapa de Uso do Solo e Vegetação (Mapa 5) demonstra que o distrito de Cachoeirinha possui um predomínio de casas em relação aos edifícios e aos conjuntos habitacionais verticais e que também grande parte de sua área verde, está restrita à parcela do Parque Estadual da Cantareira. Com relação à primeira observação, sua corroboração pode ser visualizada no mapa 6: 
Mapa 5: Uso do Solo e Cobertura Vegetal.

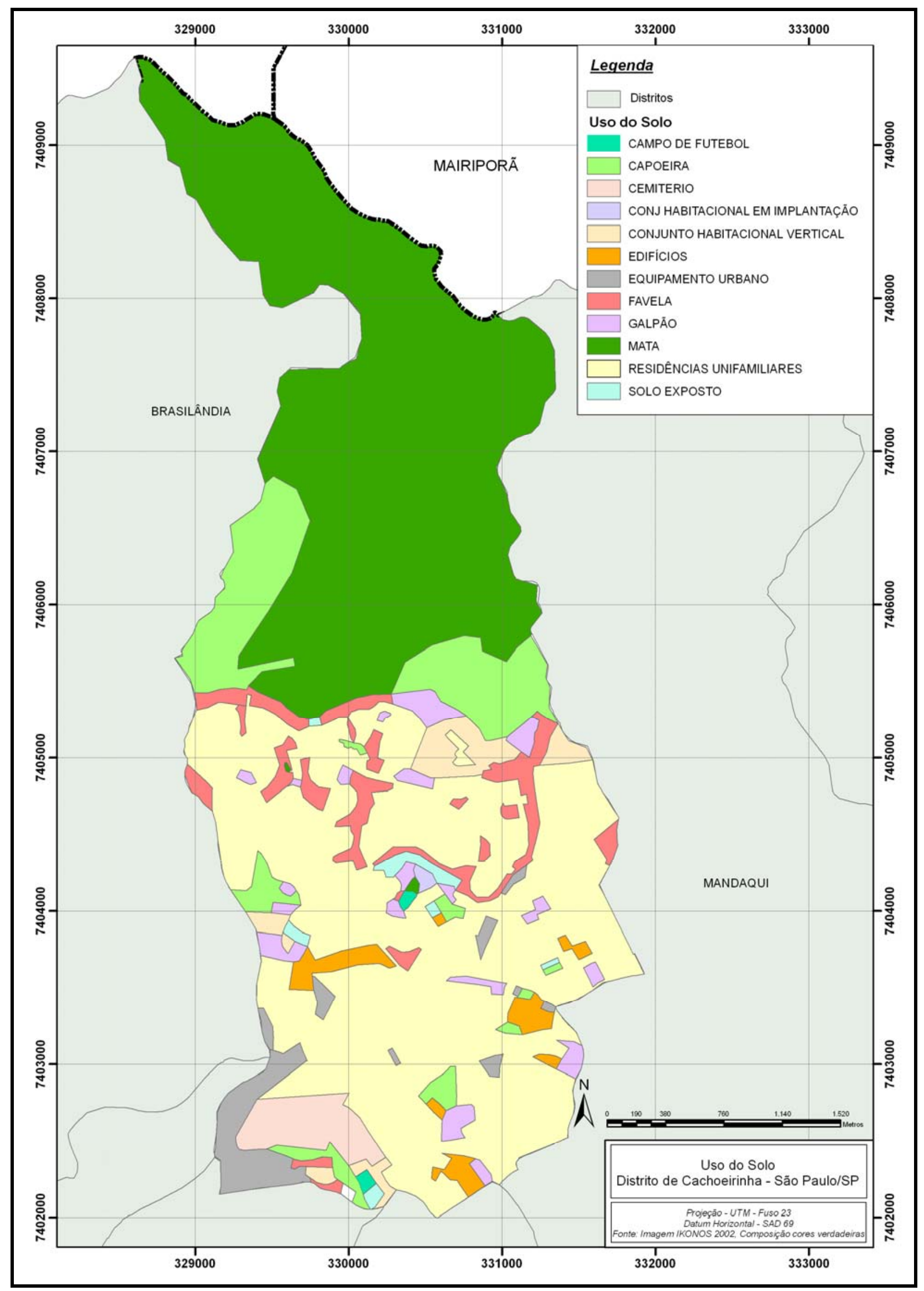

Fonte: Imagem Ikonos composição cores verdadeiras. Geolog, 2000. Elaborado pela autora, 2008. 
Mapa 6: Proporção de Casas e Edifícios no Distrito de Cachoeirinha.

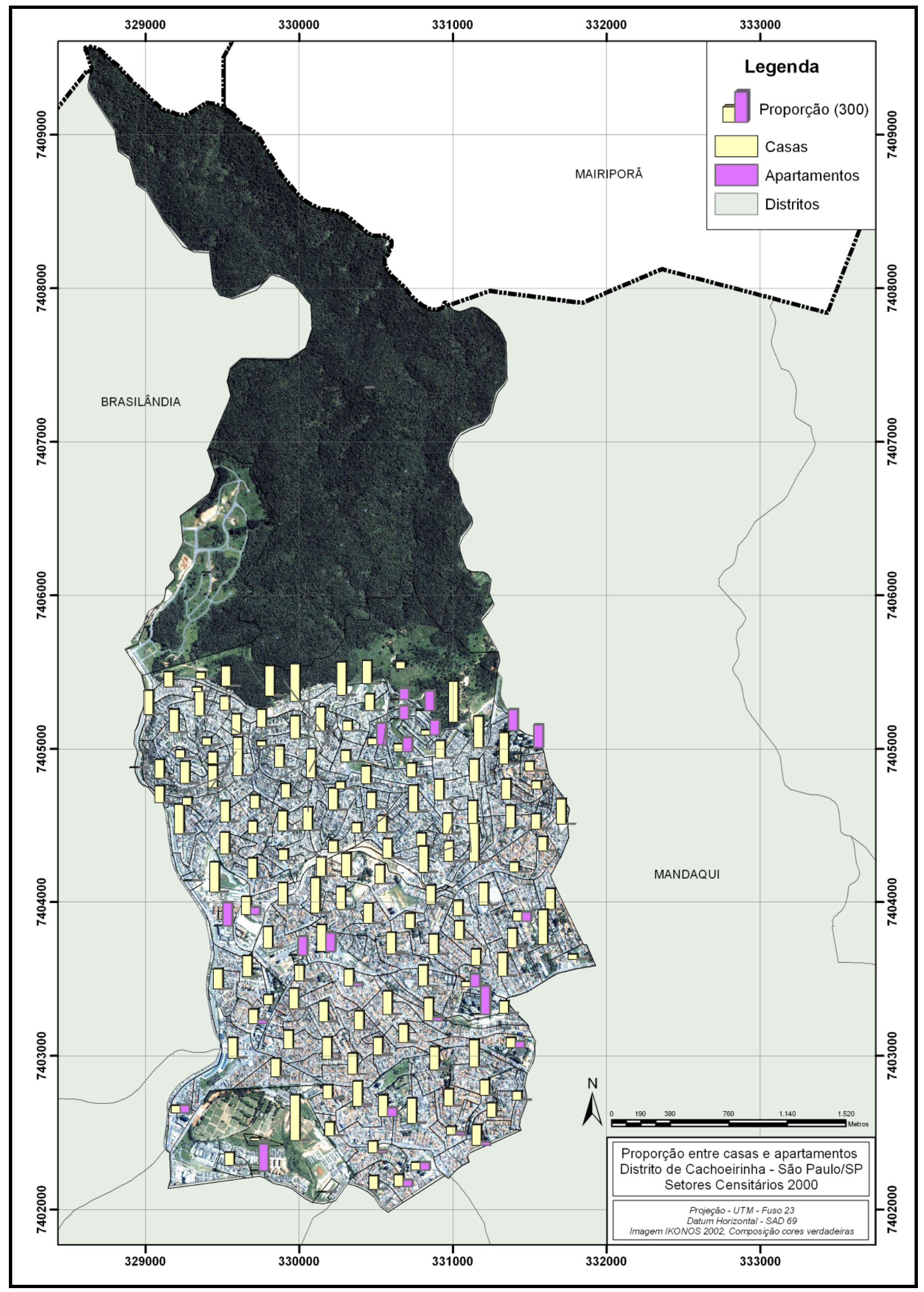

Fonte: Dados do Censo Demográfico (IBGE, 2000); Geolog, 2000. Mapa elaborado pela autora, 2008. 
É importante ressaltar os edifícios por que, paralelo ao processo de verticalização ocorre o adensamento populacional. A nossa realidade diária vem nos demonstrando que a deterioração da qualidade de vida urbana pode ser conseqüência do "empilhamento" humano em áreas restritas. (Rattner, 1978 apud in Nucci, 2001) E as conseqüências desse processo não ficam circunscritas às áreas verticalizadas, elas influenciam na qualidade de vida de toda a população ao redor, desde o vizinho até áreas mais distantes, podendo se verificar, por exemplo, uma piora do trânsito no bairro ou distrito ou mesmo piora nos serviços de transporte público.

Portanto, devido à presença maior de casas na área de estudo, o fator edifícios, ou melhor, a verticalização não pôde ser destacada como processo com influência direta na caracterização da qualidade de vida no distrito de Cachoeirinha.

\subsection{ZONAS RESIDENCIAIS HOMOGÊNEAS}

O Mapa das Zonas Residenciais homogêneas foi elaborado com a utilização de imagens Ikonos II (2002) de alta resolução e resultou nas seguintes classes interpretativas a seguir:

Zona Residencial Homogênea 1 - ZRH 1

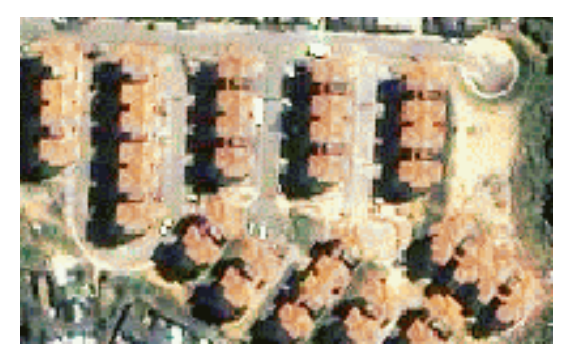

Esta Zona é formada pelo Conjunto Habitacional de Vila Nova Cachoeirinha denominada COHAB VILA NOVA CACHOEIRINHA. O conjunto localiza-se em uma área urbana dotada de infra-estrutura e de ocupação consolidada. O conjunto é rodeado pela favela Morro da Esperança, o traçado viário é regular e algumas ruas apresentam pavimentação. Praticamente não 
apresenta arborização, sendo as áreas verdes do entorno representativa devido à proximidade do Conjunto ao Cemitério de Cachoeirinha.

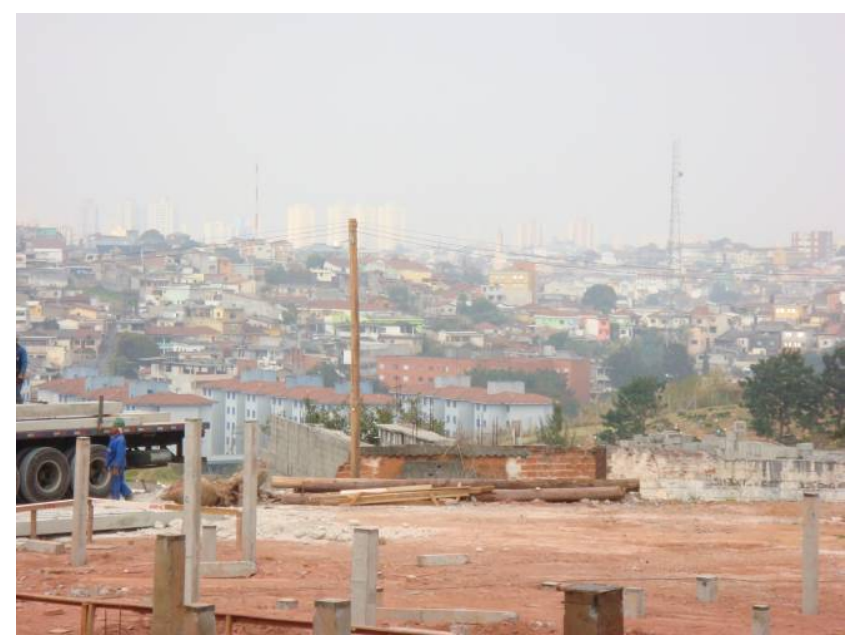

Foto 4: Conjunto Habitacional da Vila Nova Cachoeirinha ao fundo (Prédios Azuis). Limite do Cemitério da Vila Nova Cachoeirinha e no primeiro plano, novo conjunto habitacional sendo construído. Marilia Roggero, 23/09/07.

Zona Residencial Homogênea 2 - ZRH 2

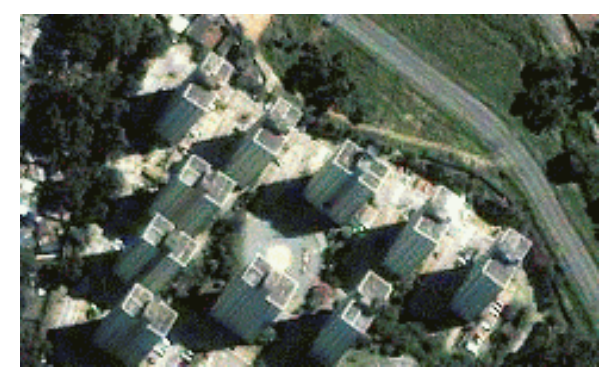

Esta zona é formada por um condomínio de edifícios. O condomínio está localizado em uma região urbana consolidada e dotado de infra-estrutura, fica bem próximo da Serra da Cantareira. Ao lado do localiza-se a favela Eucaliptos II. O sistema viário da zona é regular e as ruas são pavimentadas. Apresenta considerável arborização e inclusive uma praça no centro do conjunto. Apresenta edifícios com mais de 10 pavimentos, porém não apresenta áreas de lazer conforme os edifícios da ZRH 10. 


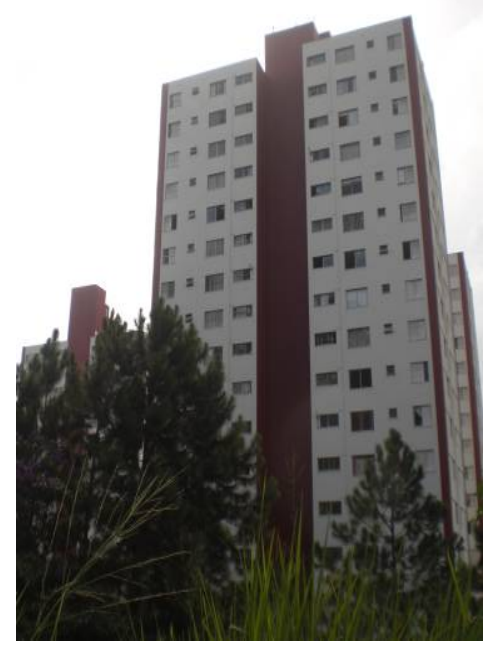

Foto 5: Prédio do condomínio Localizado na Avenida Santa Inês. Marilia Roggero 25/01/09.

Zona Residencial Homogênea 3 - ZRH 3

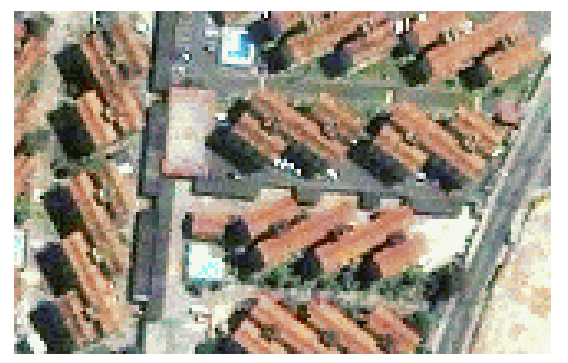

Esta zona residencial é formada também por conjunto de edifícios, entretanto, sua particularidade se encontra na área de lazer, composta por piscinas (pelo menos 3 foram identificadas), quadras de esporte e campo de futebol. A presença de arborização na área não é notável, porém a presença de jardins demonstra ter havido um planejamento ou até mesmo um projeto paisagístico para esses conjuntos de edifícios. Esse conjunto residencial localizase na Avenida Inajar de Souza, esquina com a rua Pedro D'oro. 


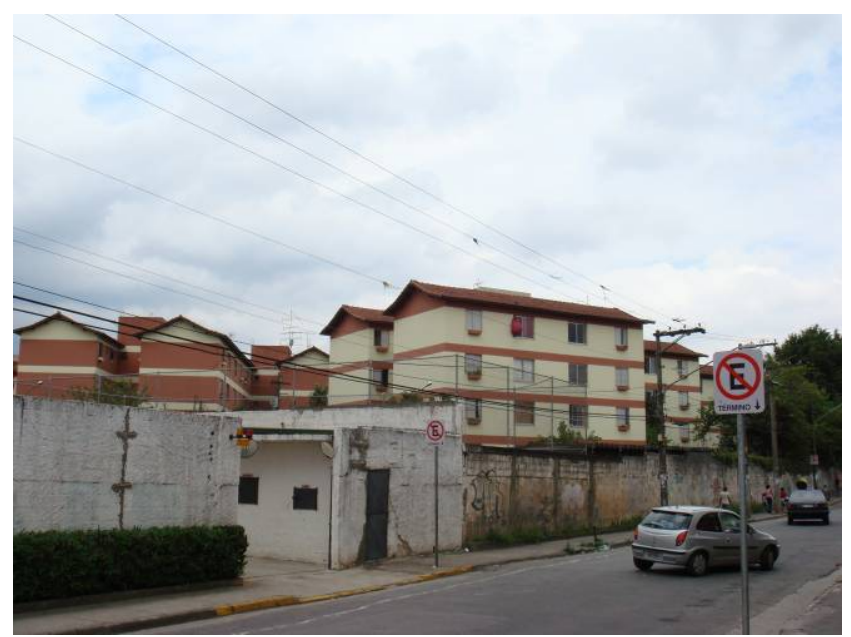

Foto 6: Conjunto Residencial Brasil 1. Marilia Roggero, 10/11/2007.

Zona Residencial Homogênea 4 - ZRH 4

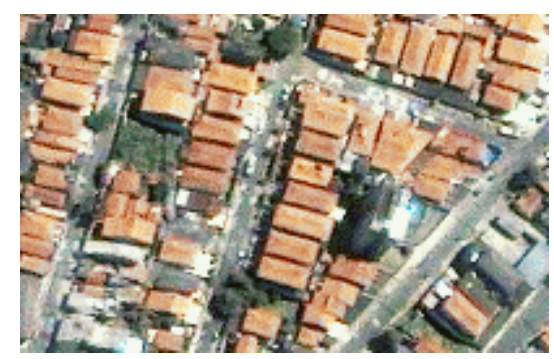

Esta Zona se caracteriza por apresentar lotes urbanos grandes, com a presença de residências unifamiliares, com texturas parecidas, tamanhos dos telhados, bem como as cores que demonstram serem construídos de cerâmica. Alguns lotes apresentam piscinas. O sistema viário é regular, as ruas são pavimentadas e seu entorno é bem arborizado.

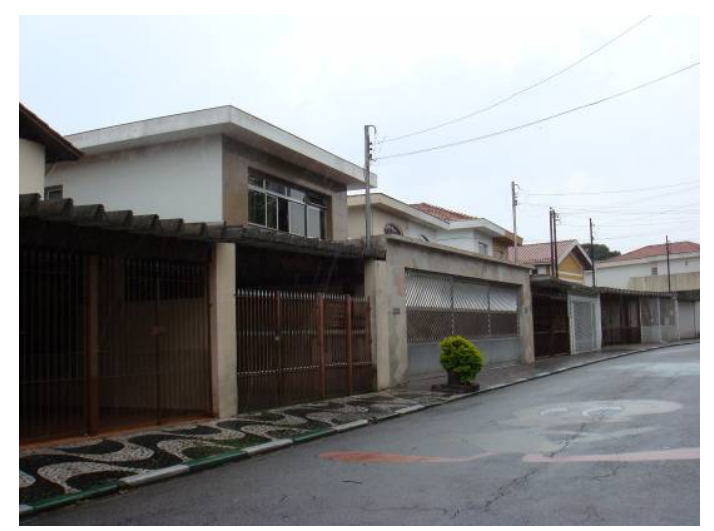

Foto 7: Casas Maiores em uma rua tranqüila (Rua Angola) do distrito de Cachoeirinha. Muitas dessas casas possuem piscina, conforme verificado na imagem de satélite. Marilia Roggero, 10/11/07. 


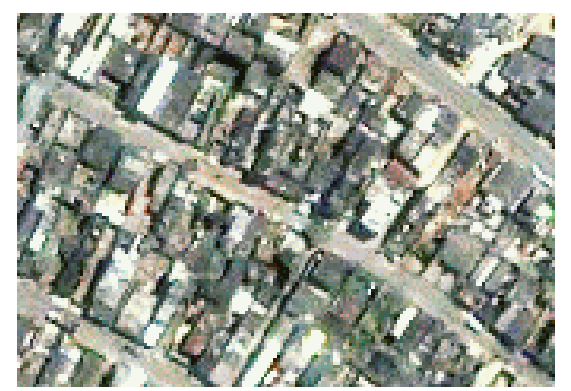

Esta zona residencial apresenta lotes bem menores que a anterior, não há praticamente a presença de telhados de cerâmica, as casas possuem laje ou telhado de amianto. As residências são horizontais e praticamente são todas autoconstruídas, a laje caracteriza a idéia da possível criação de mais um pavimento. As casas dessa zona residencial podem chegar a até quatro andares.

Praticamente não existe arborização nas ruas nem nos lotes, tomados pela construção inteira. A ocupação é consolidada, as ruas são pavimentadas, mas, não aparenta possuir boa infra-estrutura. Essa zona é rodeada de favelas que beiram a Serra da Cantareira.

A densidade das construções é expressiva, bem como a pouca arborização dos lotes e das ruas. O traçado viário é regular e as ruas são pavimentadas.

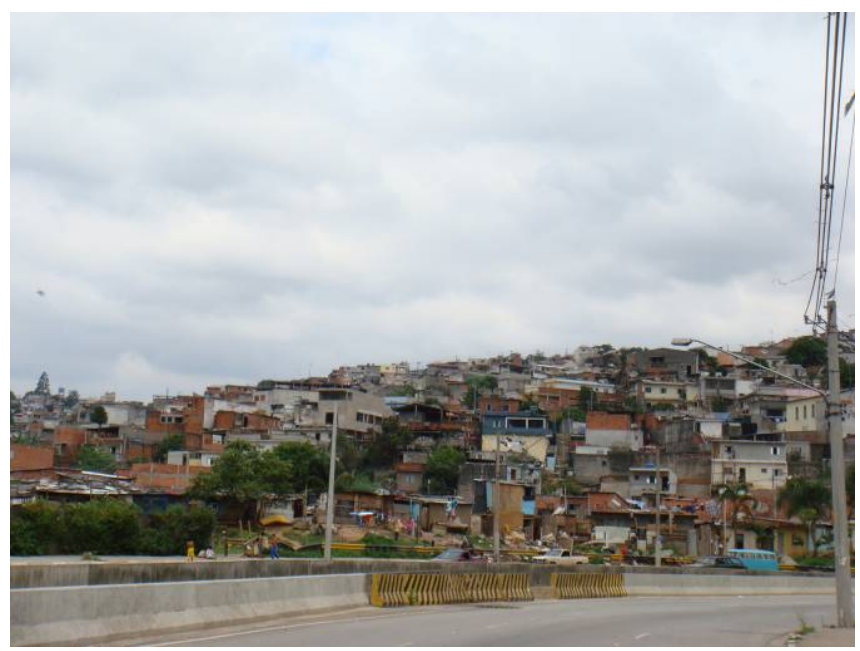

Foto 8: Vista das casas desta zona residencial (Av. Inajar de Souza). Muitas são autoconstruidas e não apresentam telhado cerâmico, nem acabamento externo. Marilia Roggero, 10/11/07. 
Zona Residencial Homogênea 6 - ZRH 6

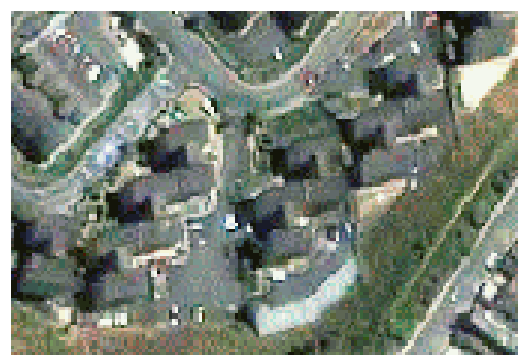

Esta zona residencial é composta por conjuntos habitacionais verticais que apresentam texturas próximas. O traçado viário da área é regular e as ruas são pavimentadas. Apesar dos conjuntos estarem localizados bem próximos a Serra da Cantareira, eles praticamente não apresentam arborização. O Conjunto habitacional Jardim Antártica, é um desses conjuntos.

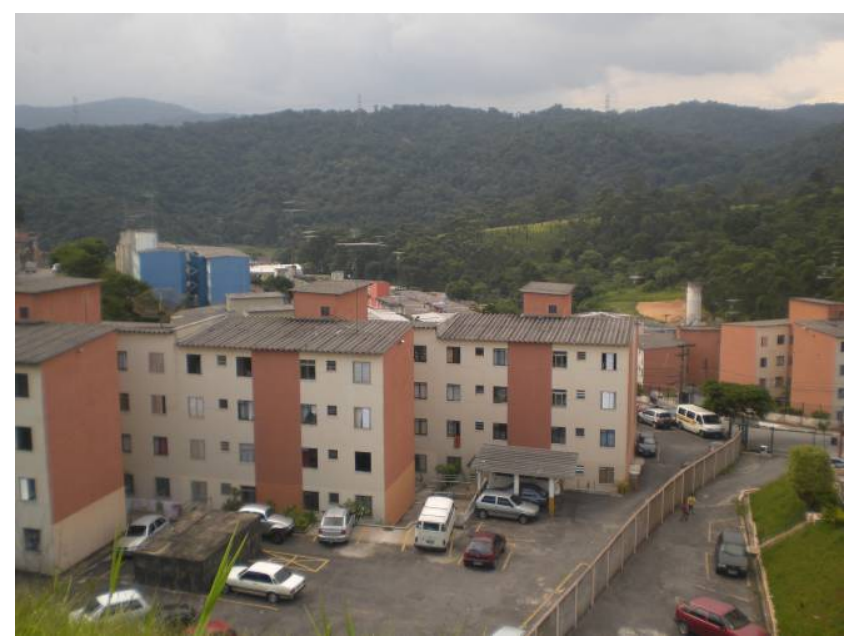

Foto 9: Vista dos prédios da Cohab Jardim Antártica. A Serra da Cantareira ao fundo. Marilia Roggero $25 / 01 / 09$ 


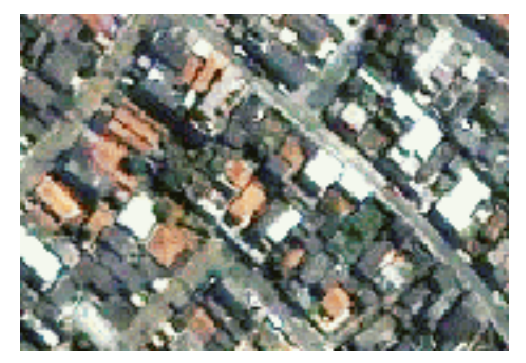

Esta zona residencial é formada por texturas mescladas de casas com telhados cerâmicos e lajes. Os lotes também possuem tamanhos aproximados. Há uma divisão melhor dos lotes do que a divisão observada na imagem de satélite.

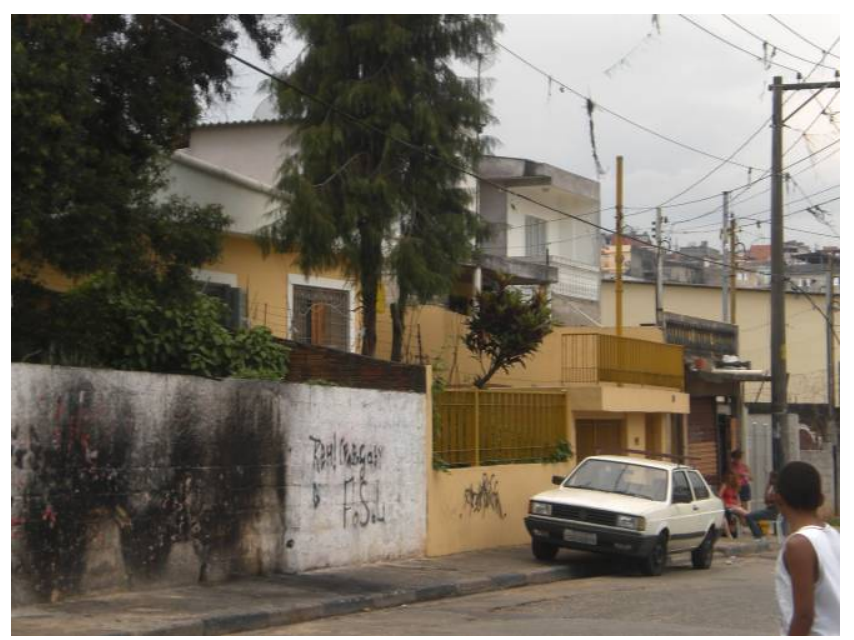

Foto 10: Casas da Rua Caiena próximo à Rua Antônio Amorim. Marilia Roggero 25/01/09. 


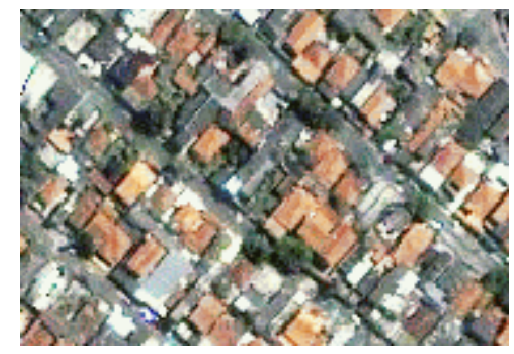

Esta zona apresenta lotes urbanos com um tamanho bom, um pouco menor do que os lotes da ZRH 4. As ruas desta zona apresentam-se arborizadas. O traçado viário é regular, a área urbana é consolidada e apresenta boa infraestrutura.

As casas desta zona apresentam predominantemente telhado de cerâmica.

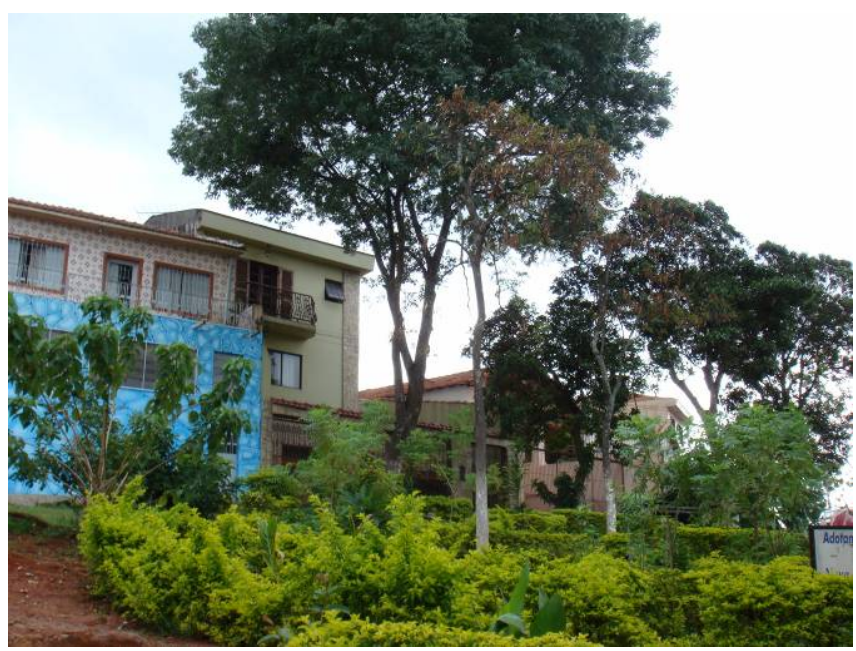

Foto 11: Sobrados antigos que fazem parte dessa zona residencial localizados na pracinha da Rua Maracaia próximos à Rua dos Patis. Ruas arborizadas conforme o relato acima. Marilia Roggero, 10/11/2007. 
Zona Residencial Homogênea 9 - ZRH 9

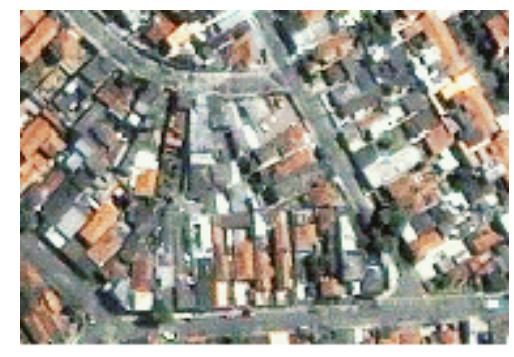

Esta zona apresenta grande densidade construtiva, traçado viário regular, ruas pavimentadas. Seus lotes são pequenos, de onde se observa a grande densidade. Essa zona residencial é composta principalmente por casas com telhado cerâmico e a arborização é menor do que na ZRH 8 e a densidade é maior.

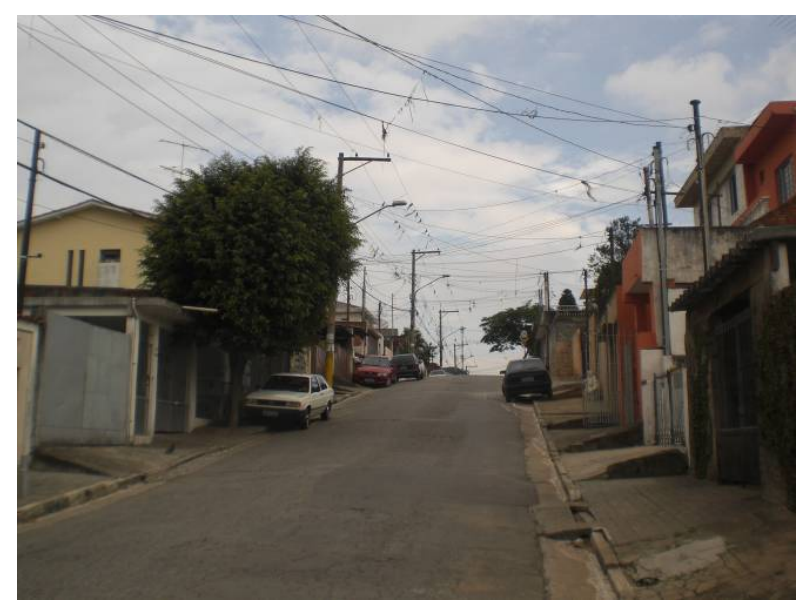

Foto 12: Sobrados da Rua Almir Rodrigues. Marilia Roggero 25/01/09. 


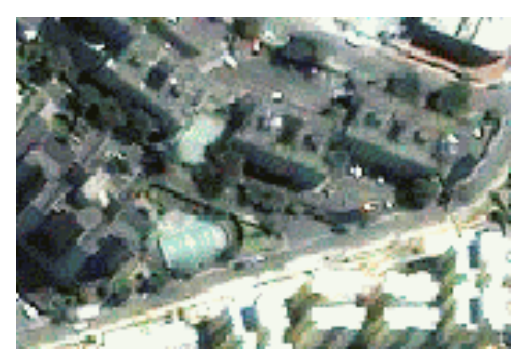

Esta zona residencial é formada por edifícios com mais de 10 pavimentos. Esses edifícios possuem ampla área de lazer e jardins planejados. Atendem principalmente à classe média. Essa zona aparece espalhada pelo distrito de cachoeirinha, mas não é muito representativa, pois conforme exposto no capítulo anterior a área de estudo é principalmente composta por residências horizontais.

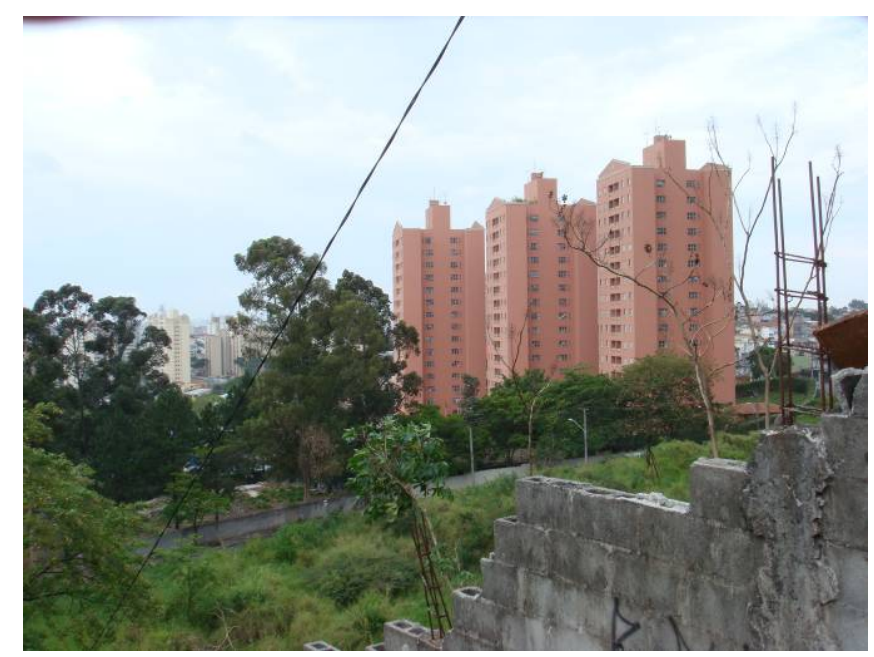

Foto 13: Edifícios que compõem essa zona residencial homogênea. Foto tirada da esquina da Rua dos Patis x Rua Franklin Amaral. Marilia Roggero, 10/11/2007. 


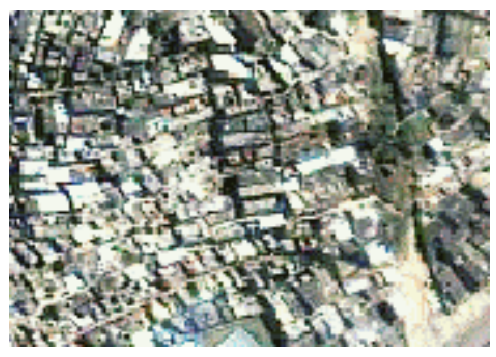

Esta zona apresenta traçado viário irregular, onde muitas ruas não são pavimentadas. É possível observar que os lotes não são definidos e não existem recuos. O tipo de telhado predominante são as lajes e telha amianto. As unidades residenciais são construídas em alvenaria sem acabamento externo, alguns são barracos, conforma a foto abaixo na beira do córrego do Bispo.

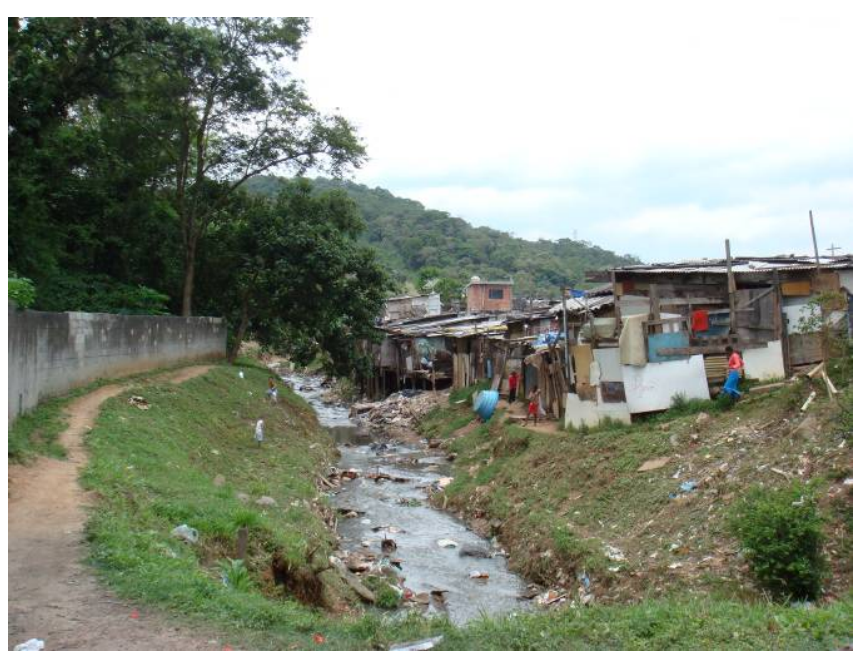

Foto 14: Favela localizada na beira do córrego, bem próximo à base da Serra da Cantareira, vista ao fundo da fotografia. Marilia Roggero, 10/11/2007. 
Mapa 7: Zonas Residenciais Homogêneas e seus códigos.

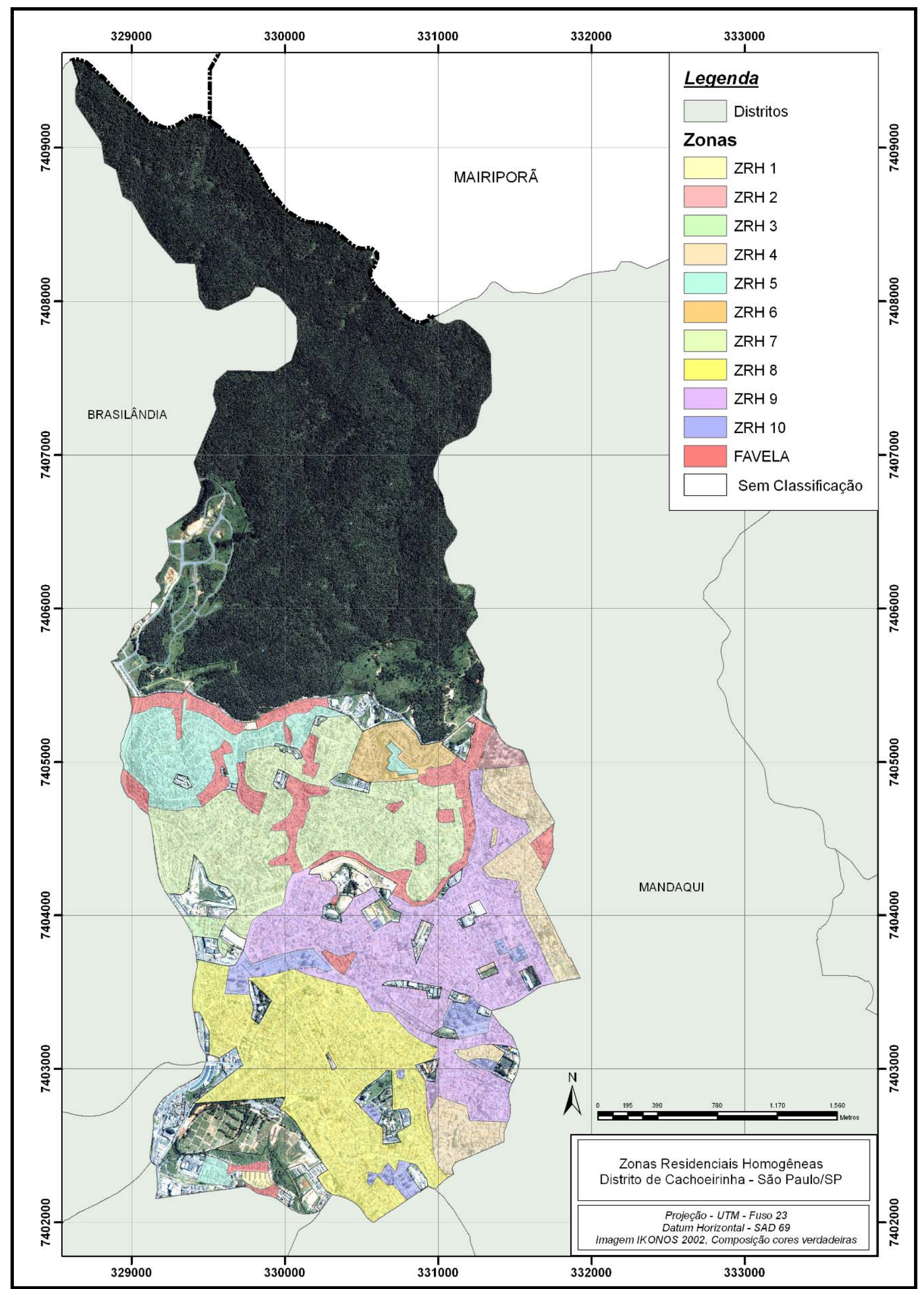

Fonte: Fonte: Imagem Ikonos composição "cores verdadeiras", 2002. Elaborado pela autora, 2008. 


\subsection{ANÁLISES MULTIVARIADAS}

Com relação às análises multivariadas, segundo Pereira (2001), a interpretação dos resultados de uma análise fatorial pode ser bastante extensiva e complexa. Esse autor ressalta em seu trabalho que com o destaque de alguns conceitos importantes e se estes forem adequadamente entendidos pode-se efetuar uma interpretação satisfatória da análise fatorial, foi essa a intenção da presente pesquisa.

No método adotado das componentes principais rodado no software SPSS 13, independente da correlação entre as variáveis, foram sempre encontrados três fatores. No modelo final, no qual ficaram os indicadores expostos na tabela 3 , o fator 1 explica 49,87\% da variância da amostra, o segundo demonstra 15,29\% e o terceiro $10,22 \%$ respectivamente. Os três fatores juntos representam $75,38 \%$ da variância total dos dados, resultado que pode ser considerado satisfatório expresso na tabela a seguir:

Tabela 5: Total da Variância Explicada

\begin{tabular}{|c|c|c|c|c|c|c|c|c|c|}
\hline \multirow[b]{2}{*}{ Fator } & \multicolumn{3}{|c|}{ Eigenvalues iniciais } & \multicolumn{3}{|c|}{ Soma dos quadrados } & \multicolumn{3}{|c|}{$\begin{array}{c}\text { Rotação da Soma dos } \\
\text { Quadrados }\end{array}$} \\
\hline & Total & $\begin{array}{c}\text { \% da } \\
\text { Variância }\end{array}$ & $\begin{array}{c}\text { Cumulativo } \\
\%\end{array}$ & Total & $\begin{array}{c}\text { \% da } \\
\text { Variância }\end{array}$ & $\begin{array}{c}\text { Cumulativo } \\
\%\end{array}$ & Total & $\begin{array}{c}\text { \% da } \\
\text { Variância }\end{array}$ & $\begin{array}{c}\text { Cumulativo } \\
\%\end{array}$ \\
\hline 1 & 4,987 & 49,870 & 49,870 & 4,987 & 49,870 & 49,870 & 3,953 & 39,532 & 39,532 \\
\hline 2 & 1,530 & 15,296 & 65,166 & 1,530 & 15,296 & 65,166 & 2,211 & 22,111 & 61,643 \\
\hline 3 & 1,022 & 10,221 & 75,386 & 1,022 & 10,221 & 75,386 & 1,374 & 13,743 & 75,386 \\
\hline 4 & ,656 & 6,561 & 81,947 & & & & & & \\
\hline 5 & ,613 & 6,130 & 88,077 & & & & & & \\
\hline 6 & ,450 & 4,496 & 92,573 & & & & & & \\
\hline 7 & ,260 & 2,595 & 95,168 & & & & & & \\
\hline 8 & ,230 & 2,295 & 97,464 & & & & & & \\
\hline 9 & ,203 & 2,025 & 99,489 & & & & & & \\
\hline 10 & 051 &, 511 & 100,000 & & & & & & \\
\hline
\end{tabular}

Fonte: Output Spss 13.

As cargas fatoriais que indicam a importância relativa dos indicadores criados a partir das variáveis do Censo em cada fator estão apresentadas na tabela a seguir: 
Tabela 6: Componentes da Matrix Rotacionada

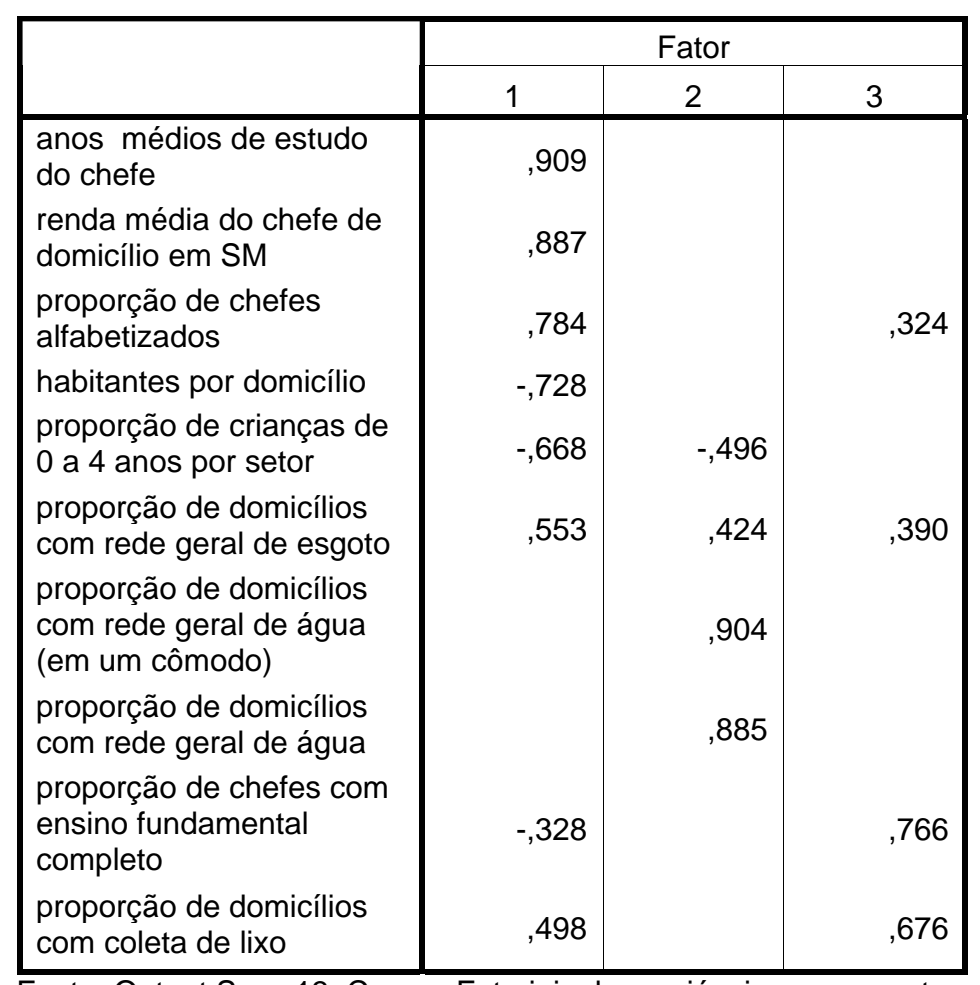

Fonte: Output Spss 13. Cargas Fatoriais das variáveis componentes.

Normalmente a matriz utilizada para a interpretação dos resultados de uma análise fatorial é a rotacionada, que se constitui de um artifício para prover maior distinção das relações encontradas. (Pereira, 2001) O método utilizado foi o Varimax, que é um método de rotação ortogonal que minimiza o número de variáveis que cada agrupamento terá. Ele simplifica a interpretação dos fatores.

Há também uma medida de adequação dos dados chamada Kaiser-MeyerOlkin measure of sampling adequecy o $\mathrm{KMO}$. Esse teste apresenta valores normalizados entre 0 e 1 e mostra qual é a proporção da variância que as variáveis apresentam em comum ou a proporção desta que são devidas a fatores comuns. Para a interpretação do resultado obtido, valores próximos a 1 indicam que o método de análise é adequado para o tratamento dos dados. Porém, os valores inferiores a 0,5 indicam a inadequação do método. (Pereira, 2001)

No caso da presente pesquisa o valor do teste KMO obtido foi 0,807 o que nos mostra uma boa adequação de possibilidades de tratamento dos dados com o método citado.

Outro teste que precede a análise fatorial e que visa à verificação de suas premissas chama-se Barllet testo $f$ Sphericity (BTS), que testa a hipótese de a matriz de correlação ser uma matriz identidade, onde a diagonal é igual a um e 
todos os outros valores sejam zero, ou seja, não existe correlação entre as variáveis.

Valores de significância maior que 0,100 indicam que os dados não são adequados para o tratamento com o método em questão; que a hipótese nula não pode ser rejeitada. Já valores menores do que 0,05 podem rejeitar a hipótese nula.

No caso da presente pesquisa o valor de significância de Barllet, mostrouse menor que 0,0005, o que permite mais uma vez confirmar a possibilidade e adequação do método de análise fatorial para o tratamento dos dados.

Conforme apresentado no capítulo 4.1.3 a análise de agrupamento ou cluster analysis, é um outro tipo de análise multivariada.

No presente estudo a análise de clusters foi elaborada a partir dos resultados da análise anterior. Dos 3 fatores gerados, foi possível criar 4 clusters, que indicam diferentes qualidades de vida no distrito de Cachoeirinha.

O método de análise de agrupamento utilizado foi o two step clusters, disponível no software SPSS 13. Este algoritmo lida com variáveis ou atributos contínuos e categóricos, e possui a vantagem de requerer um passo apenas para a execução do procedimento. Na primeira fase os registros são pré-agrupados em vários pequenos sub-agrupamentos. Em seguida, agrupamos os subagrupamentos, criados na etapa de pré-agrupamento, e inserimos o número desejado de agrupamentos, no caso 4. Por meio do uso da Two Step Cluster, os dados foram agrupados de modo que os registros dentro de um grupo sejam similares, resultando no mapa exposto a seguir.

A seguir estão expostos os resultados desta análise: 
Tabela 7: Distribuição dos Clusters

\begin{tabular}{|ll|r|r|r|}
\hline & $\begin{array}{c}\text { Número de } \\
\text { Casos }\end{array}$ & \% Combinada & \% do Total \\
\hline Cluster & 1 & 46 & $30,5 \%$ & $29,3 \%$ \\
& 2 & 73 & $48,3 \%$ & $46,5 \%$ \\
& 3 & 9 & $6,0 \%$ & $5,7 \%$ \\
& 4 & 22 & $14,6 \%$ & $14,0 \%$ \\
& Outlier (-1) & 1 &, $7 \%$ &, $6 \%$ \\
Casos Excluídos & Combined & 151 & $100,0 \%$ & $96,2 \%$ \\
Total & 6 & & $3,8 \%$ \\
& & 157 & & $100,0 \%$ \\
\hline
\end{tabular}

Fonte: Output Spss 13.

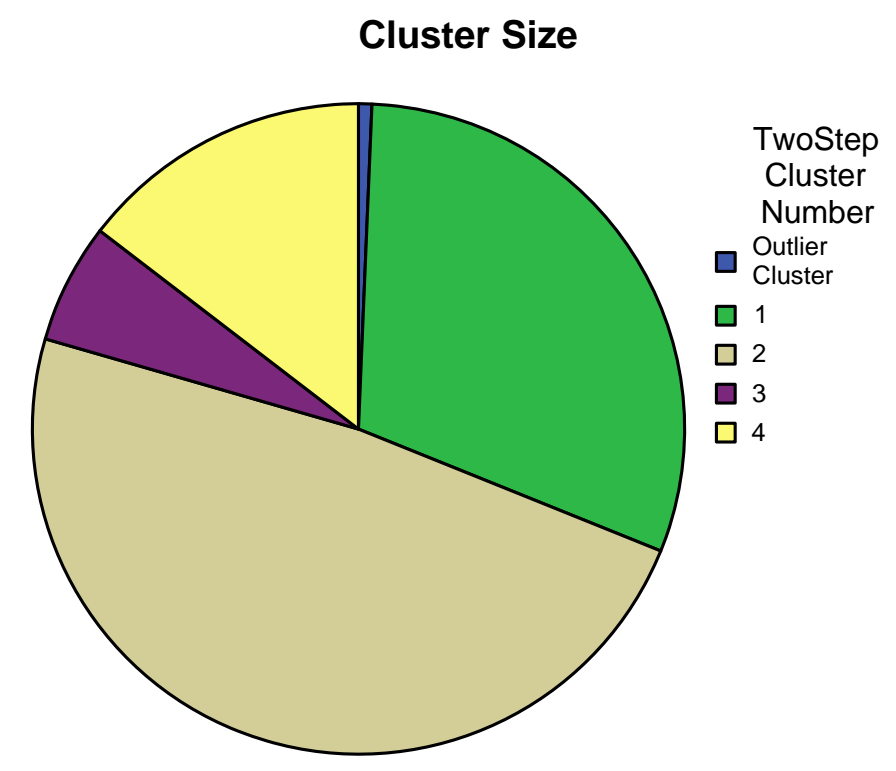

Gráfico 1: Tamanho dos Clusters gerados.

Seguem os resultados da análise de agrupamento final, elaborada com a análise anterior dos setores censitários IBGE 2000 em conjunto com a análise qualitativa das zonas residenciais homogêneas. 
Tabela 8: Distribuição dos Clusters - final

\begin{tabular}{|rl|r|r|r|}
\hline & & $\mathrm{N}$ & $\begin{array}{c}\text { \% of } \\
\text { Combined }\end{array}$ & \% of Total \\
\hline Cluster & 1 & 11 & $28,2 \%$ & $28,2 \%$ \\
& 2 & 10 & $25,6 \%$ & $25,6 \%$ \\
& 3 & 9 & $23,1 \%$ & $23,1 \%$ \\
& 4 & 9 & $23,1 \%$ & $23,1 \%$ \\
& Combined & 39 & $100,0 \%$ & $100,0 \%$ \\
Total & & 39 & & $100,0 \%$ \\
\hline
\end{tabular}

Fonte: Output Spss 13.

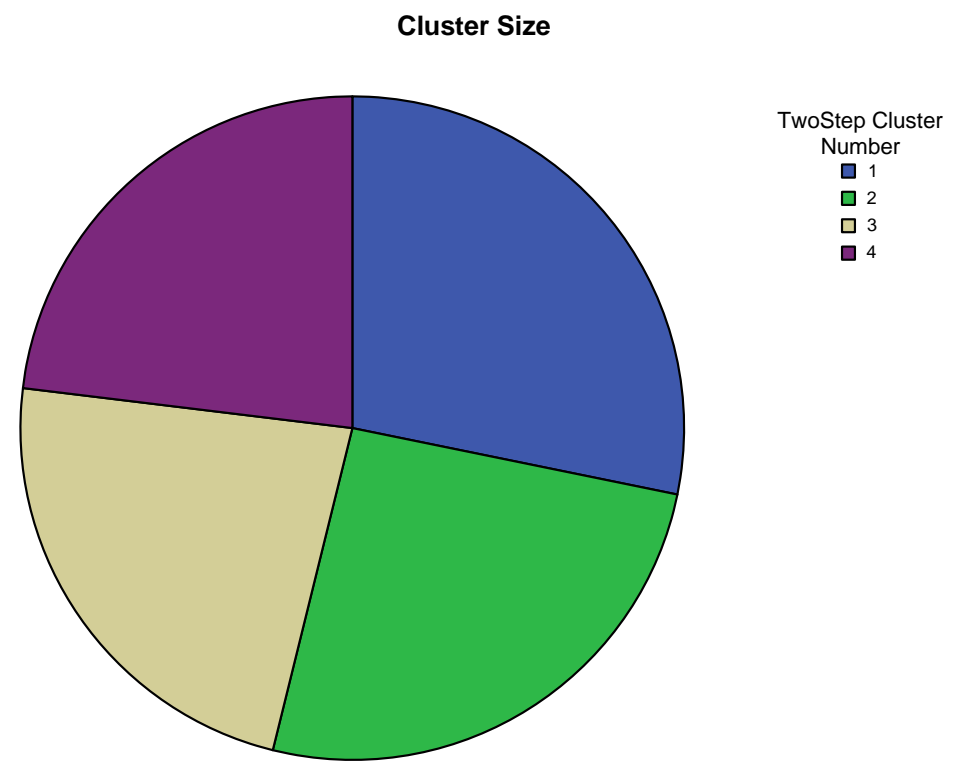

Gráfico 2: Tamanho dos Clusters gerados - final 
Mapa 8: Resultado da primeira análise de agrupamento

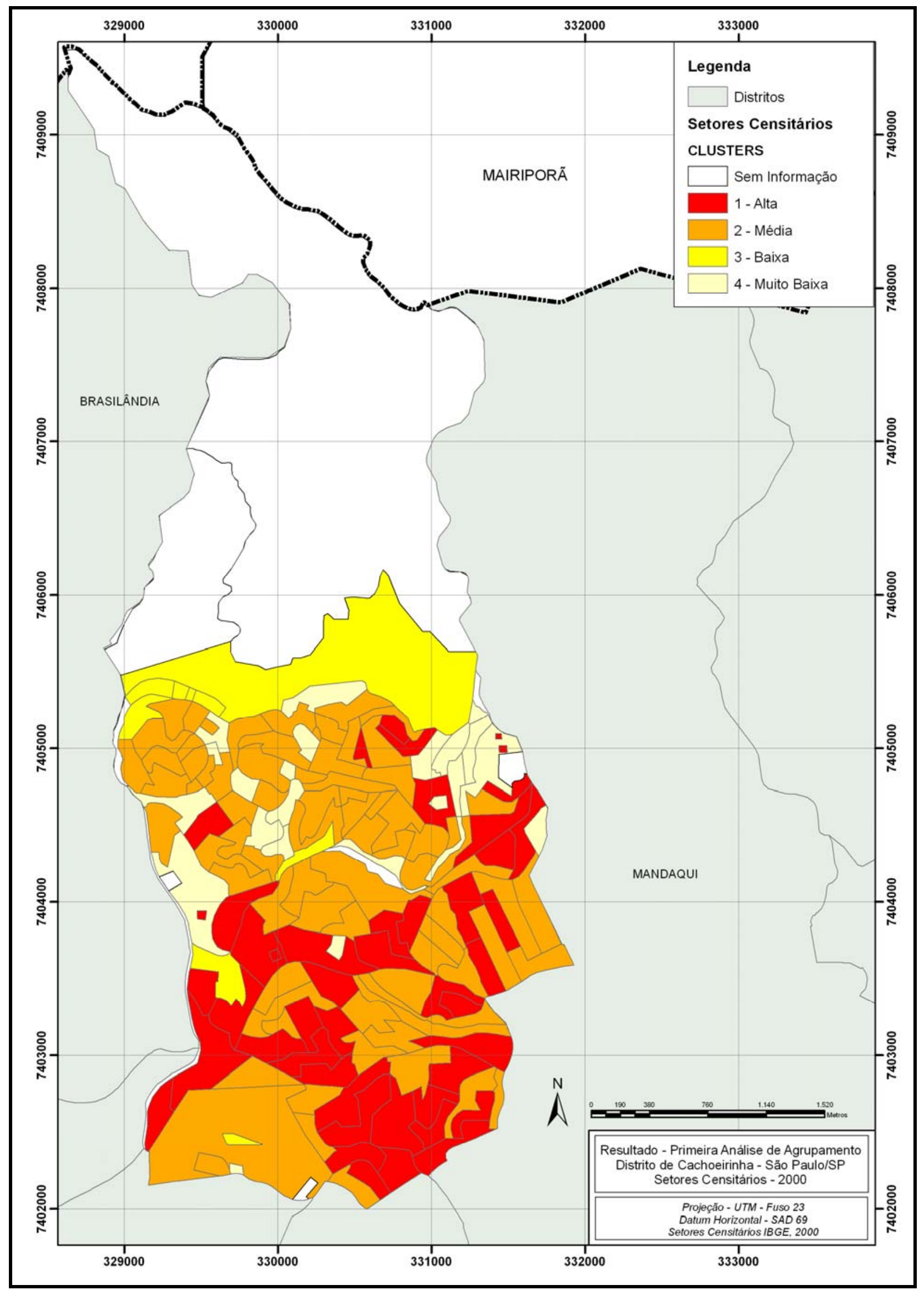

Fonte: Setores Censitários IBGE, 2000. CEM/CEBRAP, 2003. Elaborado pela autora, 2008. 
Mapa 9: Zonas Residenciais agrupadas, segundo os critérios demonstrados na metodologia.

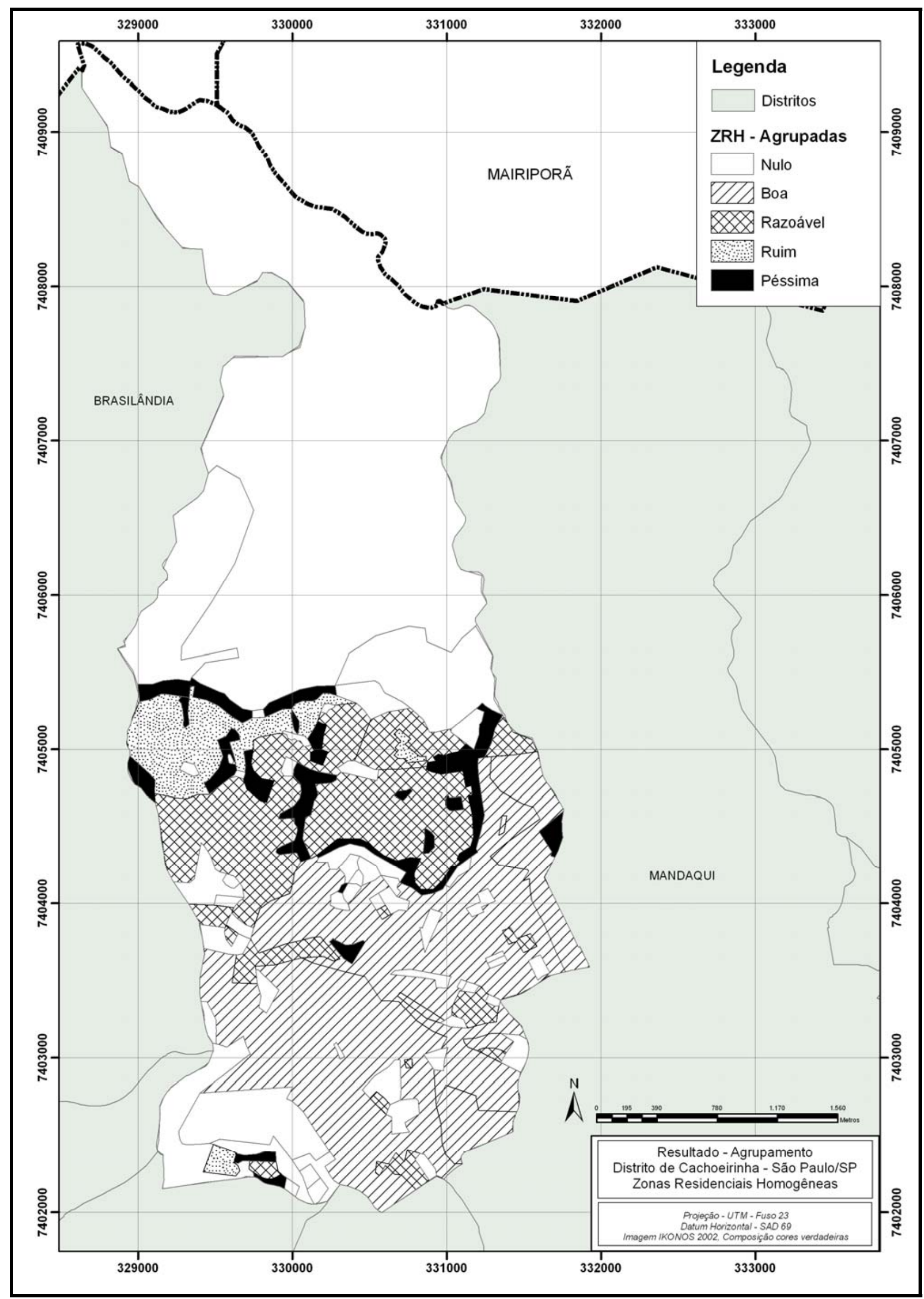

Fonte: Imagem Ikonos composição "cores verdadeiras", 2002. Elaborado pela autora, 2008. 
Mapa 10: Agrupamentos Zonas Residenciais e Setores Censitários

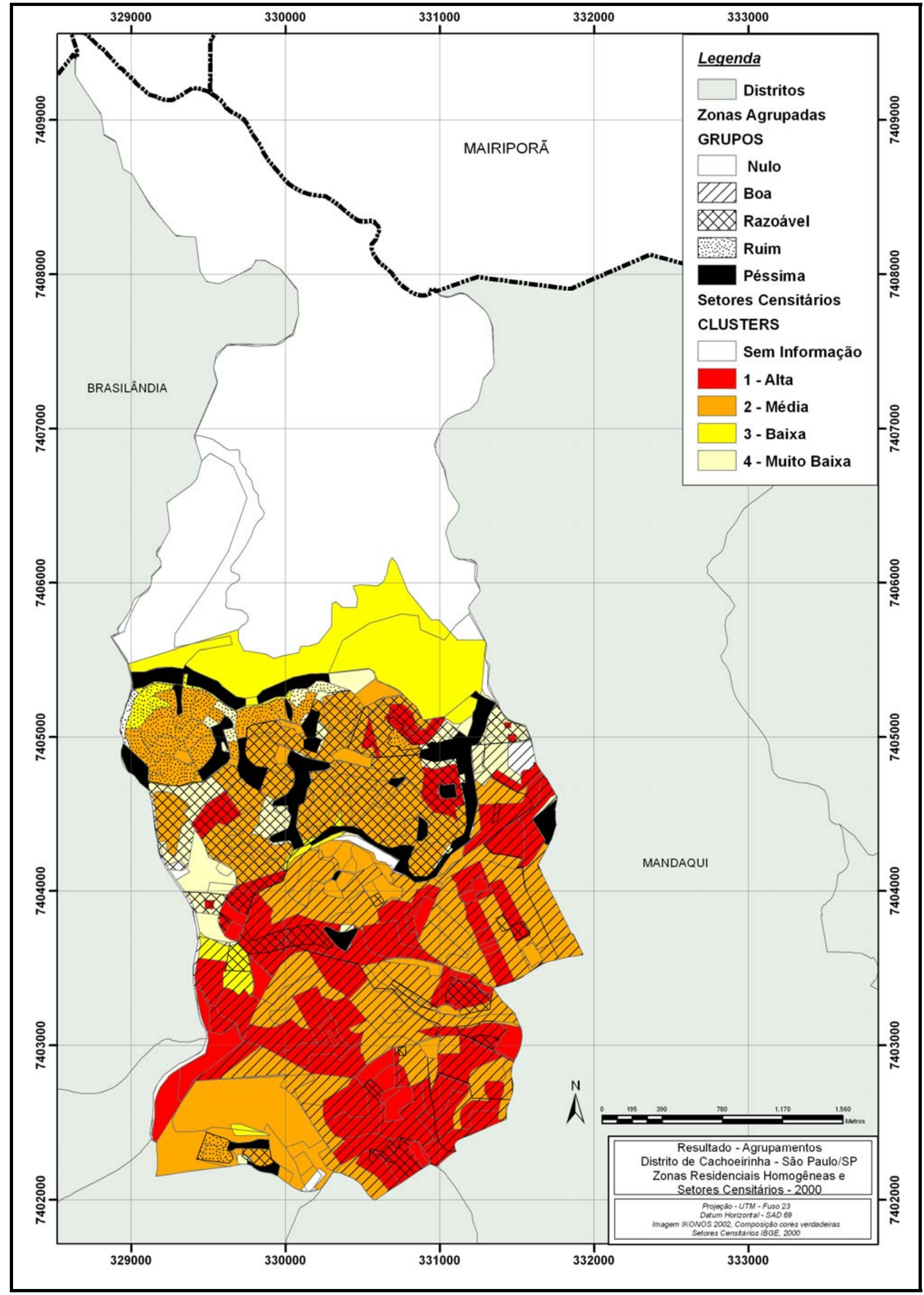

Fonte: Setores Censitários IBGE, 2000. CEM/CEBRAP, 2003. Zonas Residenciais Homogêneas. Elaborado pela autora, 2008. 
Mapa 11: Síntese Final elaborada após as análises multivariadas

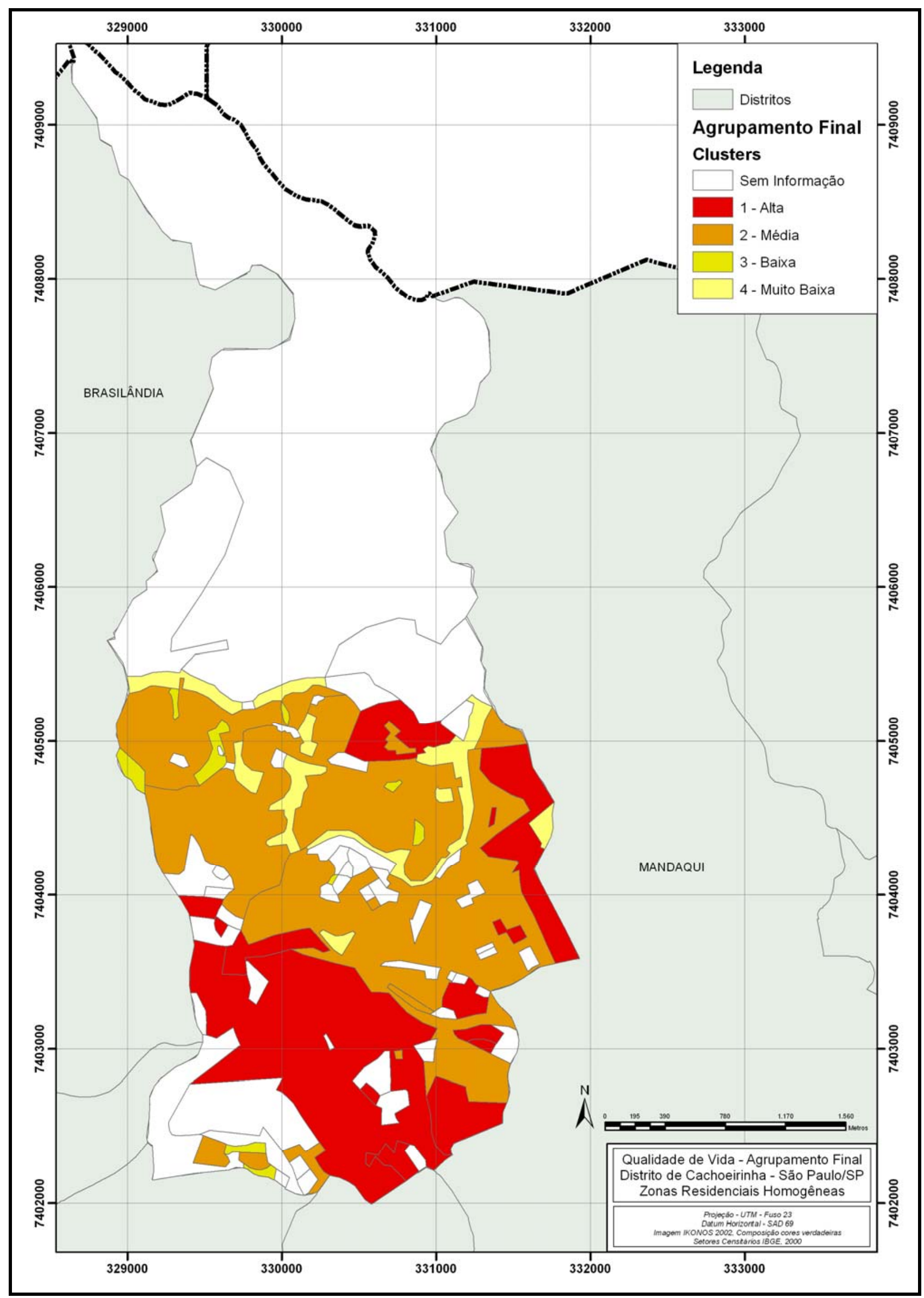

Fonte: Síntese Final elaborada após as análises multivariadas. Elaborado pela autora, 2008. 
É possível observarmos no mapa 8 áreas entremeadas com boa e média qualidade de vida, que correspondem a grande parcela do distrito de Cachoeirinha.

As áreas onde se verifica uma piora na qualidade de vida correspondem às bordas urbanas, situadas no limite do Parque Estadual da Cantareira, o que demonstra uma pressão urbana nesta região. As piores áreas, onde a qualidade de vida foi classificada como baixa e muito baixa, correspondem majoritariamente às favelas e áreas mais precárias do distrito.

Os resultados da primeira análise de cluster demonstram que a qualidade de vida, segundo a metodologia e os crit adotados, se deteriora a medida que nos dirigimos à porção norte da parte urbana do distrito da Cachoeirinha, limítrofe ao Parque Estadual da Cantareira. A classe 1 agrega os setores censitários que possuem melhores condições de saneamento, socioeconômicas e demográficas do distrito, as moradias dessa classe são amplas e geralmente possuem telhados cerâmicos (fatos verificados em campo). A classe 2 demonstra que em alguns aspectos houve pequeno decréscimo na qualidade de vida, tanto na parte demográfica, assim como nas condições de saneamento e socioeconômica. Essa classe possui setores espalhados por toda área de estudo e também localizados ao norte do distrito, na parcela urbana, onde os terrenos são menores, as construções também e geralmente, os telhados são de amianto ou lajes. A classe 3 apresenta os setores localizados na porção extremo norte da parte urbana do distrito de Cachoeirinha, onde os resultados da análise de agrupamento demonstram uma queda maior no nível de rendimento dos chefes de família que ficam entorno de um salário mínimo, nos anos de estudo dos chefes de família por volta de cinco anos; bem como as condições de saneamento, principalmente no que se refere à coleta de lixo e a proporção casas com esgoto ligado à rede geral.

A classe 4 corresponde às manchas de favelas verificadas nas imagens de satélite interpretadas, em campo e também comparada à base de favelas (vetorial) elaborada pelo Centro de Estudos da Metrópole em 2003. As áreas de favelas apresentam uma ligeira concentração na porção urbana norte da área de estudo.

Com relação ao mapa 11 da síntese final, os resultados apresentados de acordo com a metodologia adotada, demonstram uma boa qualidade de vida no distrito de maneira geral. Poucas são as zonas residenciais que se enquadraram 
nas classes baixas e muito baixas; isso porque os valores extraídos das primeiras análises multivariadas, correspondente ao censo demográfico 2000, apresentam bons resultados para todos os indicadores que fizeram parte das análises. Entretanto, vale ressaltar que as concentrações das classes 3 e 4, baixa e muito baixa respectivamente, continuam sendo na porção norte e urbanizada do distrito, reforçando os resultados da primeira análise.

\section{CAPÍTULO 7}

\section{CONSIDERAÇÕES FINAIS}

De maneira geral, os resultados obtidos no trabalho, de acordo com a fundamentação teórica e a metodologia adotada, demonstraram que a união das técnicas de sensoriamento remoto, cartografia digital e estatísticas multivariadas são adequadas para análise intra-urbana.

A metodologia proposta apresentou bons resultados para análise da qualidade de vida no distrito de Cachoeirinha e ao contrário do que muitas vezes se pensa na ciência Geográfica, o auxílio dos números, ou melhor, das técnicas estatísticas, pode ser um grande aliado na demonstração de resultados de maneira mais objetiva. É certo que a seleção de variáveis pode ser considerada arbitrária, no entanto, se isto ocorresse dessa maneira, os modelos de análises multivariadas propostos, dificilmente estariam adequados e com isso, não seriam encontrados resultados com distribuição espacial coerentes dos fenômenos.

A presente metodologia não está finalizada, há muito para se aprimorar visando retratar e compreender melhor a qualidade de vida urbana. Tem-se a intenção de, futuramente, entender melhor também a união das três técnicas citadas acima dando ênfase principalmente, na contribuição das estatísticas multivariadas.

O crescimento concêntrico da cidade também pôde ser observado nos resultados apresentados por meio dos mapas elaborados neste estudo; mas, principalmente, no mapa síntese final, confirmando assim que os estudos de morfologias das cidades muito têm a explicar a respeito da distribuição espacial nas áreas urbanas, e que estes podem auxiliar outras pesquisas relacionadas à 
segregação espacial bem como à qualidade de vida urbana, caso da presente pesquisa.

Verificou-se também, que as técnicas de sensoriamento remoto, fotointerpretação, processamento digital de imagens têm muito a colaborar na caracterização e análise de áreas urbanas e, apesar de todas as dificuldades apontadas ao longo da pesquisa, os resultados obtidos com as zonas residenciais homogêneas foram de grande valia para a caracterização e análise da qualidade de vida urbana no distrito estudado. 


\section{CAPÍTULO 8}

\section{BIBLIOGRAFIA}

ANDREUS, F. M. \& WHITEY, S. B. Social Indicators of well-being: America's perception of quality of life. New York: Plenum Press, 1976.

ARAÚJO, E. H. Geraldi. Análise Multi-temporal de Cenas do Satélite Quickbird usando um novo paradigma de classificação de imagens e inferências espaciais: Estudo de caso - Belo Horizonte, MG. 2005. 175 páginas. Dissertação de Mestrado (Pós-Graduação em Sensoriamento Remoto) - INPE, São José dos Campos.

ARCHELA, R. S. A Cartografia no Pensamento Geográfico. Disponível em http://br.geocities.com/cartografiatematica/textos/Pensamen.html Acesso em $13 / 11 / 07$

BICHIR, R. M. Segregação e acesso a políticas públicas no município de São Paulo. 2006. 128 páginas. Dissertação de Mestrado - FFLCH/USP, São Paulo.

BOWEN, B. D. \& KRONISCK, J. A. \& WEISBERG, H. F. An Introduction to survey research, polling and data analysis. Londres:SAGE Publications, 1996.

CÂMARA, G. \& MONTEIRO, M. \& MEDEIROS J. S. de Representações Computacionais do Espaço: Um diálogo entre a Geografia e a Ciência da Geoinformação. Divisão de Processamento de Imagens Instituto Nacional de Pesquisas Espaciais (DPI/INPE), São José dos Campos: 2000.

CANTERO, M. J. S. y otros. Indicadores de Calidad de Vida. Madrid: Centro de Investigaciones Sociológicas, 2003.

CARLOS, Ana Fani A. A (Re)produção do Espaço Urbano. São Paulo:Editora da Universidade de São Paulo, 1994. 
CASTELLS, Manuel. A Questão Urbana. Rio de Janeiro: Paz e Terra, 1983.

CEM/CEBRAP, Censo Demográfico por Setores Censitários IBGE 2000 - Bases de dados com cartografias e variáveis censitárias (dados demográficos, socioeconômicos, caracterização dos domicílios etc.) da Região Metropolitana de São Paulo, 2003.

CHRISTOFOLETTI, Antonio. As características da Nova Geografia. In: CHRISTOFOLETTI, A. (org) Perspectivas da Geografia. São Paulo: DIFEL, 1985, 2 cd. Cap 5, p. 71-101

CHANOND, C. Recent changes in the land market on the urban fringe of Bangkok. ITC Journal, 1987.

CONAMA, (Conselho Nacional do Meio Ambiente). Resolução 369, 28 de março de 2006.

CHEN, K. An approach to linking remotely sensed data and areal census data. International Journal of Remote Sensing, v. 23, n.1, p. 37-48, Jan. 2002.

CORDEIRO, H. A. A Qualidade de Vida Urbana e as Condições de Saúde: O Caso do Rio de Janeiro. Souza, A. (Org) In Qualidade da Vida Urbana. Rio de Janeiro: Zahar Editores, 1982.

CÔRREA, Lobato Roberto. O Espaço Urbano. São Paulo: Ática, 2005.

DRUCK, S.; CARVALHO, M.S.; CÂMARA, G.; MONTEIRO, A.V.M. (eds) "Análise Espacial de Dados Geográficos". Brasília, EMBRAPA : 2004.

EHLERS, M. Sensoriamento Remoto para usuários de SIG - Sistemas sensores e Métodos: as Exigências e a Realidade. BLASCHKE \& KUX, T. H. (Orgs.) In Sensoriamento Remoto e SIG Avançados - Novos Sistemas Sensores, Métodos Inovadores. São Paulo: Oficina de Textos, 2005. (19-32) 
EVANGELISTA, H. de A. A Geografia Crítica no Brasil. Disponível em Conceitos Básicos em Ciência da Geoinformação. Disponível em http://www.feth.ggf.br/GeografiaCr\%C3\%ADtica.htm. Acesso em 10/10/08.

EVANGELISTA, H. de A. Geografia Crítica, 2006. Disponível em http://www.feth.ggf.br. Acesso em 05/10/08.

FAISSOL, S. Urbanização e metropolização no Brasil. São Paulo: le, 1972.

FERREIRA, J. S. W. Globalização e urbanização subdesenvolvida. In São Paulo em perspectiva. Volume 14, nº 4 São Paulo / Oct. Dec. 2000.

FILHO, O. Bueno Amorim \& FILHO, N. de Sena. A Morfologia das Cidades. Goiânia: Ed. Vieira, 2005.

FILHO, U. Doria Introdução à Bioestatística - para simples mortais. São Paulo: Negócio Editora, 1999.

FLORENZANO, T. Gallotti, Imagens de Satélite para Estudos Ambientais. São Paulo, Oficina de Textos, 2002.

FORESTI, C. Estimativas populacionais e de crescimento de áreas urbanas no Estado de São Paulo, com a utilização de imagens Landsat. São José dos Campos, SP. 1978 - 128 páginas. Dissertação de Mestrado - INPE, São José dos Campos.

FRÚGOLI JÚNIOR, Heitor. Centralidades em São Paulo: Trajetórias, Conflitos e Negociações na Metrópole. São Paulo: Cortez/Edusp, 2000.

GERARDI, L. H. O. \& SILVA, B. C. N. Quantificação em Geografia. São Paulo:Difel, 1981.

GUIMARÃES, J. R. S. \& JANNUZZI, P. M. Indicadores sintéticos no processo de formulação e avaliação de políticas públicas: Limites e Legitimidade. XIV Encontro 
Nacional de Estudos Populacionais, ABEP, realizado em Caxambu- MG - Brasil, de 20- 24 de Setembro de 2004.

GUIMARÃES, R. P. Ecopolítica em Áreas Urbanas: A Dimensão Política dos Indicadores de Qualidade Ambiental. Souza, A. (Org) In Qualidade da Vida Urbana. Rio de Janeiro: Zahar Editores, 1982.

HARVEY, D. Explanation in Geography. Londres, 1969.

HOGAN, D. J. Indicadores Sócio-demográficos de Sustentabilidade. HOGAN, D. J. in Migração e Ambiente nas Aglomerações Urbanas. Campinas: Núcleo de Estudos da População/UNICAMP, 2001.

HOGAN, D. J. \& MARANDOLA, E. J. Para uma conceituação interdisciplinar da vulnerabilidade. in (Org.) In Novas Metrópoles Paulistas. População, Vulnerabilidade e Segregação. Campinas: Núcleo de Estudos da População, 2006. (23-50)

IBGE, Noções básicas de cartografia disponível em http://www.ibge.gov.br/home/geociencias/cartografia/manual_nocoes/representac ao.html. Acesso em 09/05/2008.

JACOBI, P. Cidade e Meio Ambiente, percepções e práticas em São Paulo. São Paulo: Annablume, 2006.

JANUZZI, P. M. Indicadores Sociais na formulação e avaliação de Políticas Públicas - Revista Brasileira de Administração Pública, Rio de Janeiro, V. 36 p. 51-72, Janeiro/fevereiro 2002.

JORDAN, R. Os problemas das metrópoles latino-americanas frente à crise. In América Latina: Crise nas Metrópoles. São Paulo: SEMPLA, 1985. (13-25)

JORNAL FREGUESIA NEWS/Santana News/Folha do Limão - 06 de agosto de 2000. 
JUNIOR, B. W. Planejamento de urbanização de Favelas. Caracterização sócioeconômica-ambiental de favelas a partir de dados censitários do IBGE. 2005. 131 páginas. Dissertação de mestrado - Escola Politécnica - USP.

KRAUS, P. S.; SENGER, L. Estimation population photographically determined residential land use types. Remote Sensing of Environment, v.3,n.1, p. 35-42, 1974.

KÜPFER, Gerard, TURKSTRA, Jan \& HOFSTEE, Paul. Spatial growth of unplanned areas in Nairobi. ITC Journal, 1987.

KURKDJIAN, M. L. N. O. Um método para a identificação e análise de setores residenciais urbanos homogêneos, através de dados de sensoriamento remoto, com vistas ao planejamento urbano. 1986. 146 páginas. Tese de Doutorado FAU/USP, São Paulo.

LACOSTE, Y. A Geografia, isso serve, em primeiro lugar, para fazer a guerra. Campinas: Papirus, 1993.

LUCHIARI, A. As Tecnologias para Análise do Espaço. Informe - Informativo da FFLCH/USP, São Paulo, Nova Série, n²5, p.1-4, outubro 2001.

Imagens da Metrópole. CARLOS \& OLIVEIRA, A. F. A. \& A. U. (Orgs.) In Geografias de São Paulo, Volume I - Representação e Crise da metrópole. São Paulo:Contexto , 2003. (231-245)

KAWAKUBO \& MORATO, A. \& F. S. \& R. G. Aplicações de Sensoriamento Remoto na Geografia. In Praticando a Geografia - Técnicas de Campo e Laboratório. São Paulo: Oficina de Textos, 2005. (33-54)

MARTINES \& FERREIRA A. \& F. S. \& R.

G. \& M. R. \& R. V Mapeamento da Qualidade de vida Urbana no Município de Osasco/SP. Artigo apresentado no III Encontro da Associação Nacional de Pós Graduação e Pesquisa em Ambiente e Sociedade - Maio, 2006. 
MACK, C., MARSH, S.E. \& HUTCHINSON, C.F. Application of Aerial Photography and GIS Techniques in the Development of a Historical Perspective of Enviromental Hazards at the Rural-Urban Fringe. Peer-Reviewed Article, 1993.

MARQUES, E. Elementos Conceituais da Segregação, da pobreza urbana e da ação do Estado. MARQUES \& TORRES, E. \& H. (Orgs.) In São Paulo: Segregação, Pobreza e Desigualdades Sociais. São Paulo:Senac, 2005. (19-56)

Espaço e grupos sociais na virada do século XXI. MARQUES \& TORRES, E. \& H. (Orgs.) In São Paulo: Segregação, Pobreza e Desigualdades Sociais. São Paulo:Senac, 2005. (57-80)

MARQUES \& SARAIVA, E. \& C. A dinâmica social das favelas da Região Metropolitana de São Paulo. MARQUES \& TORRES, E. \& H. (Orgs.) In São Paulo: Segregação, Pobreza e Desigualdades Sociais. São Paulo:Senac, 2005. $(143-168)$

MARTINELLI, M. As Representações da Metrópole em Mapa. CARLOS \& OLIVEIRA, A. F. A. \& A. U. (Orgs.) In Geografias de São Paulo, Volume I Representação e Crise da metrópole. São Paulo:Contexto , 2003. (213-270)

MAUTNER, Y. A periferia como expansão do capital in DEÁK, Csaba \& SCHIFFER, S. Ramos (Orgs) O Processo de Urbanização no Brasil. São Paulo: Edusp, 2004.

MONTEIRO, COSTA \& FANTIN, M. V., M. A. \& M. A relevância de uma infraestrutura geoinformacional como subsídio ao desenvolvimento de políticas públicas. ALMEIDA, CÂMARA \& MONTEIRO, C. M., G. \& A. M. V. (Orgs.) in Geoinformação em Urbanismo: cidade real X cidade virtual, 2007. (132-159)

MORATO, R. G. Análise da Qualidade de Vida Urbana no Município de Embu/SP. 2004. 108 páginas Dissertação de Mestrado - FFLCH/USP , São Paulo. 
MOURA, A. C. M. Geoprocessamento na Gestão e Planejamento Urbano. Belo Horizonte: Editora da autora, 2003.

NAHAS, M. I. P. Metodologia de Construção de Índices e Indicadores Sociais, como Instrumentos Balizadores de Gestão Municipal e Qualidade de Vida Urbana: Uma síntese da experiência de Belo Horizonte. HOGAN, D. Joseph et al (Org) in Migração e Ambiente nas Aglomerações Urbanas. Campinas: Núcleo de Estudos de População/Unicamp, 2001. (465-487)

Indicadores Intra-Urbanos como instrumento de gestão da qualidade de vida urbana em grandes cidades: discussão teórico metodológica. Disponível em http://www.idhs.pucminas.br/textos. Acesso em 08/05/07.

NAPOLEÃO, R. M. Criminalidade Urbana e condições de vida na região administrativa de Campinas (SP) no ano de 2000: Uma Análise Espacial. 2005. 121 páginas Dissertação de Mestrado - UNESP, Rio Claro.

NATIONAL RESEARCH COUNCIL of U.E.A, Community and Quality of Life. Washington, 2002.

NOVO, E. M. L. de Sensoriamento remoto: princípios e aplicações. Sao Paulo: Edgard Blucher, 1989.

NUCCI, J. C. Qualidade Ambiental \& Adensamento Urbano. São Paulo: Humanitas/FFLCH/USP, 2001.

NUSSBAUM, M. \& SEN, A. The Quality of Life. Oxford: Oxford University Press, 1993.

OLIVEIRA, M. A. Análise da Qualidade Ambiental urbana na Bacia Hidrográfica do Rio Itaquera no município de São Paulo - Um Ensaio Metodológico. 2006. 177 páginas Dissertação de Mestrado - FFLCH/USP, São Paulo. 
PAIVA, J. E. M. Mapeando a qualidade de vida em Minas Gerais Utilizando dados de 1991 e 2000. 2003. 155 páginas. Tese de Doutorado - Unesp/Rio Claro.

PAVÃo, M. Estudo da Dinâmica de Urbanização na Bacia do Córrego do Bananal Município de São Paulo, através da utilização de técnicas de Sensoriamento Remoto e Geoprocessamento. 2005. 159 páginas. Dissertação de Mestrado FFLCH/USP, São Paulo.

PENNA, N. A. Urbanização, Cidade e Meio Ambiente. GEOUSP - Espaço e Tempo, São Paulo, No 12, pp. XX, 2002.

PEREIRA, J. C. R. Análise de dados qualitativos - Estratégias Metodológicas para as Ciências da Saúde, Humanas e Sociais. São Paulo: EDUSP, 2001.

PEREIRA \& SAMPAIO, M. R. de \& P. C. X. Habitação em São Paulo. Estudos Avançados, Volume 17 n 48. São Paulo, 2003.

PIERSON, D. Estudos de Ecologia Humana. São Paulo: Martins, 1948.

PMSP - Prefeitura do Município de São Paulo - Geolog, Mapa Oficial da Cidade de São Paulo, 2.1.2, 2000

PMSP - Prefeitura do Município de São Paulo - Plano Diretor Estratégico do Município de São Paulo, 2002.

PMSP - Boletim da Subprefeitura Casa Verde/Cachoeirinha - Março/2007 disponível em ww2.prefeitura.sp.gov.br//arquivos/subprefeituras/boletim/2007. Acesso em 13/03/2007.

PNUD - Programa das Nações Unidas para o Desenvolvimento, 1998. Atlas de Desenvolvimento Humano no Brasil. Fundação João Pinheiro (FJP) e Instituto de Pesquisas Econômicas Aplicadas (IPEA). 
RAFFO, J. G. da G. Posicionamento de Objetos sobre a superfície da Terra. VENTURI, L. A. B. (Org.) In Praticando a Geografia - Técnicas de Campo e Laboratório. São Paulo: Oficina de Textos, 2005. (13-18)

REIS, N. G. Notas sobre dispersão urbana e novas formas de tecido urbano. São Paulo: Via das Artes, 2006.

ROLNIK, R. Cidade e políticas urbanas no Brasil: velhas questões, novos desafios. In: Henrique Rattner. (Org.). Brasil no limiar do século XXI: alternativas para construção de uma sociedade sustentável. São Paulo: EDUSP, 2000. (105124)

ROSS, J. L. S. São Paulo: A cidade e as águas. CARLOS \& OLIVEIRA , A. F. A. \& A. U. (Orgs.) In Geografias de São Paulo, Volume II - A Metrópole do Século XXI. São Paulo: Contexto, 2004. (183-219)

SABESP, Saneamento Básico do Estado de São Paulo. www.sabesp.com.br. Acesso em 05/06/2008.

SANTOS \& MARTINS, L. D. \& I. A Qualidade de Vida Urbana. O Caso da Cidade do Porto. Disponível em www.fep.up.pt/investigacao/workingpapers. Acesso em 04/07/07.

SANTOS, M. Por uma Geografia nova: da crítica da Geografia a uma Geografia crítica. São Paulo: Editora da Universidade de São Paulo, 2002.

SEABRA, O. C. de L. São Paulo: Os Bairros e a Periferia. CARLOS \& OLIVEIRA, A. F. A. \& A. U. (Orgs.) In Geografias de São Paulo, Volume I - Representação e Crise da metrópole. São Paulo:Contexto , 2003. (271-311)

SEADE, Índice Paulista de Vulnerabilidade Social. Disponível em www.seade.gov.br/ipvs. Acesso em 19/07/2007. 
SLIWIANY, R. M. Estatística Social - Como medir a qualidade de vida. Curitiba: Araucária Cultural, 1987.

SPOSATI, A. Cidade, Território, Exclusão/Inclusão Social. Geo Brasil 2000. São Paulo. 16/06/2000.

SOUZA, Gustavo C. O. Construção de um Indicador Sócioambiental: O exemplo do município de São Paulo. In São Paulo Perspectiva. Fundação SEADE. 2006.

SOUZA, Íris. M. Análise do Espaço Intra-Urbano para Estimativa Populacional Intercensitária Utilizando Dados Orbitais de Alta Resolução. 2004. 87 páginas Dissertação de Mestrado (Mestrado em Planejamento Urbano e Regional) INPE, São José dos Campos.

SVMA - Secretaria do Verde e Meio Ambiente - Atlas Ambiental do Município de São Paulo, SVMA e SEMPLA - Secretaria Municipal do Planejamento Urbano, 2002.

TORRES, H. G.; FERREIRA, M. P.; DINI, N. P. Indicadores sociais: porque construir novos indicadores como o IPRS. São Paulo em Perspectiva, v. 17, p. 8090, 2003.

TORRES, H. Medindo a Segregação. MARQUES \& TORRES, E. \& H. (Orgs.) In São Paulo: Segregação, Pobreza e Desigualdades Sociais. São Paulo:Senac, 2005. (81-100)

A fronteira paulistana. MARQUES \& TORRES, E. \& H. (Orgs.) In São Paulo: Segregação, Pobreza e Desigualdades Sociais. São Paulo:Senac, 2005. (101-120)

VENTURI, L. A. B. O papel da técnica no processo de produção Científica. VENTURI, L. A. B. (Org.) In Praticando a Geografia - Técnicas de Campo e Laboratório. São Paulo: Oficina de Textos, 2005. (13-18) 
VERONA, J. A. Qualidade Ambiental e de Vida na cidade de Várzea Paulista SP: Estudo de Caso. 2002. 97 páginas. Dissertação de Mestrado (Instituto de Geociências e Ciências Exatas, UNESP). Rio Claro - SP.

VILLAÇA, F. Espaço Intra - Urbano no Brasil. São Paulo : Studio Nobel: FAPESP: Lincoln Institute, 1998.

WILHEIM, Jorge. "Intervenções na Paisagem Urbana de São Paulo". São Paulo: Instituto Florestan Fernandes de Políticas Públicas, 2000. 


\section{CAPÍTULO 9}

\section{ANEXOS}

Outputs spss - análise fatorial

\begin{tabular}{|c|c|c|c|c|c|c|c|c|c|c|c|}
\hline \multicolumn{12}{|c|}{ n Matrix } \\
\hline & & $\begin{array}{l}\text { proporcao de } \\
\text { domicilios } \\
\text { com rede } \\
\text { geral de água }\end{array}$ & $\begin{array}{c}\text { proporcao de } \\
\text { domicilios } \\
\text { com rede } \\
\text { geral de } \\
\text { água (em um } \\
\text { cômodo) }\end{array}$ & $\begin{array}{c}\text { proporcalo de } \\
\text { domicilios } \\
\text { com rede } \\
\text { geral de } \\
\text { esgoto }\end{array}$ & $\begin{array}{l}\text { proporcao de } \\
\text { domicilios } \\
\text { com coleta } \\
\text { de lixo }\end{array}$ & $\begin{array}{c}\text { renda media } \\
\text { do chéfe de } \\
\text { domicilio em } \\
\text { sm }\end{array}$ & $\begin{array}{l}\text { proporcao de } \\
\text { chefes } \\
\text { alfabetizados }\end{array}$ & $\begin{array}{c}\text { proporcao de } \\
\text { chefes com } \\
\text { ensino } \\
\text { fundamental } \\
\text { completo }\end{array}$ & $\begin{array}{c}\text { anos medios } \\
\text { de estudo do } \\
\text { chefe }\end{array}$ & $\begin{array}{c}\text { Habitantes } \\
\text { por } \\
\text { Domicilios } \\
\end{array}$ & $\begin{array}{c}\text { proporcaso de } \\
\text { criancas de } \\
\text { a } 4 \text { anos por } \\
\text { setor }\end{array}$ \\
\hline \multirow[t]{10}{*}{ Comelation } & $\begin{array}{l}\text { proporcao de domicilios } \\
\text { com rede geral de água }\end{array}$ & 1,000 & .761 & .546 & .274 & .311 & .461 & .141 & .388 &.,- 303 & -.592 \\
\hline & $\begin{array}{l}\text { proporcao de domicilios } \\
\text { com rede geral de água } \\
\text { (em um cốmodo) }\end{array}$ & .761 & 1,000 & .420 & 193 & .278 & .388 & .111 & .359 & $\cdot .248$ & .491 \\
\hline & $\begin{array}{l}\text { proporcao de domicilios } \\
\text { com rede geral de esgoto }\end{array}$ & .546 & .420 & 1,000 & .471 & .477 & .623 & 090 & .524 & -.378 & -.623 \\
\hline & $\begin{array}{l}\text { proporcao de domicilios } \\
\text { com coleta de lixo }\end{array}$ & .274 & .193 & .471 & 1,000 & .313 & .539 & .139 & .374 & -.287 & -.433 \\
\hline & $\begin{array}{l}\text { renda media do chefe de } \\
\text { domićílio em } \mathrm{sm}\end{array}$ & .311 & .278 & .477 & .313 & 1,000 & .669 & $\cdot .242$ & .927 & -.530 & -.560 \\
\hline & $\begin{array}{l}\text { proporcao de chefes } \\
\text { alfabetizados }\end{array}$ & .461 & .388 & .623 & .539 & .669 & 1,000 & 038 & .781 & -.514 & .628 \\
\hline & $\begin{array}{l}\text { proporoao de chefes com } \\
\text { ensino fundamental } \\
\text { completo }\end{array}$ & .141 & .111 & .090 & 139 &,- 242 & 038 & 1,000 & -.177 & .159 & .024 \\
\hline & $\begin{array}{l}\text { anos medios de estudo } \\
\text { do chefe }\end{array}$ & .388 & .359 & .524 & .374 & .927 & .781 & -.177 & 1,000 &,- 602 & -.609 \\
\hline & Habitantes por Domicilios & -.303 & $\cdot .248$ & -378 & -.287 & -.530 & -.514 & .159 & $\cdot .602$ & 1,000 & .682 \\
\hline & $\begin{array}{l}\text { proporeaso de criancas de } \\
0 \text { a } 4 \text { anos por setor }\end{array}$ & -.592 & -.491 & -.623 & .433 &,- 560 & .628 & $\cdot .024$ &., 609 & .682 & 1,000 \\
\hline \multirow[t]{10}{*}{ Sig. (1-tailed) } & $\begin{array}{l}\text { proporcao de domicilios } \\
\text { com rede geral de água }\end{array}$ & & .000 & .000 & .000 & .000 & .000 & .042 & .000 & .000 & .000 \\
\hline & $\begin{array}{l}\text { proporcao de domicilios } \\
\text { com rede geral de água } \\
\text { (em um cômodo) }\end{array}$ & .000 & & .000 & & .000 & .000 & .088 & .000 & .001 & .000 \\
\hline & $\begin{array}{l}\text { proporcao de domicilios } \\
\text { com rede geral de esgoto }\end{array}$ & .000 & .000 & & .000 & .000 & .000 & .136 & .000 & .000 & .000 \\
\hline & $\begin{array}{l}\text { proporcao de domicilios } \\
\text { com coleta de lixo }\end{array}$ & .000 & .009 & .000 & & .000 & .000 & .045 & .000 & .000 & .000 \\
\hline & $\begin{array}{l}\text { renda media do chefe de } \\
\text { domićlio em sm }\end{array}$ & .000 & .000 & .000 & .000 & & .000 & .001 & .000 & .000 & .000 \\
\hline & $\begin{array}{l}\text { proporcao de chefes } \\
\text { alfabetizados }\end{array}$ & .000 & .000 & .000 & .000 & .000 & & .322 & .000 & .000 & .000 \\
\hline & $\begin{array}{l}\text { proporoao de chefes com } \\
\text { ensino fundamental } \\
\text { completo }\end{array}$ & .042 & .088 & .136 & .045 & .001 & .322 & & .015 & .025 &, 387 \\
\hline & $\begin{array}{l}\text { anos medios de estudo } \\
\text { do chefe }\end{array}$ & .000 & .000 & .000 &, 000 & .000 & .000 & .015 & & .000 & ,000 \\
\hline & Habitantes por Domicilios & .000 & .001 & .000 & .000 & .000 & .000 & .025 & .000 & & ,000 \\
\hline & $\begin{array}{l}\text { proporcao de criancas de } \\
0 \text { a } 4 \text { anos por setor }\end{array}$ & .000 & .000 & .000 & .000 & .000 & .000 & .387 & .000 & .000 & \\
\hline
\end{tabular}

Determinant $=, 00$

KMO and Bartlett's Test

\begin{tabular}{|c|c|c|}
\hline \multicolumn{2}{|c|}{$\begin{array}{l}\text { Kaiser-Meyer-Olkin Measure of Sampling } \\
\text { Adequacy. }\end{array}$} & 807 \\
\hline $\begin{array}{l}\text { Bartlett's Test of } \\
\text { Sphericity }\end{array}$ & $\begin{array}{l}\text { Approx. Chi-Square } \\
\text { df } \\
\text { Sig. }\end{array}$ & $\begin{array}{r}1027,780 \\
45 \\
, 000\end{array}$ \\
\hline
\end{tabular}




\begin{tabular}{|c|c|c|c|c|c|c|c|c|c|c|c|}
\hline \multicolumn{12}{|c|}{ Anti-image Matrices } \\
\hline & & \begin{tabular}{|c|} 
proporcao de \\
domicilios \\
com rede \\
geral de agua \\
\end{tabular} & $\begin{array}{c}\text { proporcao de } \\
\text { domicilios } \\
\text { com rede } \\
\text { geral de } \\
\text { agua (em um } \\
\text { cômodo) }\end{array}$ & $\begin{array}{c}\text { proporcao de } \\
\text { domicilios } \\
\text { com rede } \\
\text { geral de } \\
\text { esgoto }\end{array}$ & $\begin{array}{c}\text { proporcaa de } \\
\text { domicilios } \\
\text { com coleta } \\
\text { de lixo }\end{array}$ & $\begin{array}{c}\text { renda media } \\
\text { do chefe de } \\
\text { domicilio em } \\
\text { sm }\end{array}$ & $\begin{array}{c}\text { proporcao de } \\
\text { chefes } \\
\text { alfabetizados } \\
\end{array}$ & $\begin{array}{c}\text { proporcao de } \\
\text { chefes com } \\
\text { ensino } \\
\text { fundamental } \\
\text { completo }\end{array}$ & $\begin{array}{c}\text { anos medios } \\
\text { de estudo do } \\
\text { chefe }\end{array}$ & $\begin{array}{c}\text { Habitantes } \\
\text { por } \\
\text { Domicilios } \\
\end{array}$ & \begin{tabular}{|c} 
proporcao de \\
criancas de 0 \\
a 4 anos por \\
setor \\
\end{tabular} \\
\hline \multirow{10}{*}{ Ant-image Covariance } & $\begin{array}{l}\text { proporcao de domicilios } \\
\text { com rede geral de agua }\end{array}$ & .332 &,- 234 &,- 081 & .017 & .010 &,- 014 & -026 &,- 002 &,- 029 & .076 \\
\hline & $\begin{array}{l}\text { proporcao de domicilios } \\
\text { com rede geral de agua } \\
\text { (em um cômodo) }\end{array}$ & -234 & .408 & ,014 & .033 & ,021 & ,007 & -013 &,- 024 &,- 032 & .030 \\
\hline & $\begin{array}{l}\text { proporcao de domicilios } \\
\text { com rede geral de esgoto }\end{array}$ & -081 & .014 & .466 &,- 093 &,- 020 &,- 073 & -025 & .008 & -039 & .085 \\
\hline & $\begin{array}{l}\text { proporcao de domicilios } \\
\text { com coleta de lixo }\end{array}$ & .017 & .033 &,- 093 & .650 & .006 &,- 120 & -071 & .005 &,- 012 & .053 \\
\hline & $\begin{array}{l}\text { renda media do chefe de } \\
\text { domicilio em } \mathrm{sm}\end{array}$ & .010 & .021 &,- 020 & .006 & .122 & .036 & .053 & -086 & -039 & .031 \\
\hline & $\begin{array}{l}\text { proporcao de chefes } \\
\text { alfabetizados }\end{array}$ &,- 014 & .007 &,- 073 &,- 120 & .036 & .265 &,- 059 &,- 073 &,- 007 & .023 \\
\hline & $\begin{array}{l}\text { proporcao de chefes com } \\
\text { ensino fundamental } \\
\text { completo }\end{array}$ & -026 & -013 & -025 & -071 & .053 & -059 & 812 & .001 & -091 & .041 \\
\hline & $\begin{array}{l}\text { anos medios de estudo } \\
\text { do chefe }\end{array}$ &,- 002 &,- 024 & .008 & .005 & -.086 & -.073 & .001 & .084 & .051 & -.017 \\
\hline & Habitantes por Domicifios & -029 &, 032 & .039 &, 012 & .039 & -007 & -091 & .051 & .431 & -194 \\
\hline & $\begin{array}{l}\text { proporcao de criancas de } \\
0 \text { a } 4 \text { anos por setor }\end{array}$ & .076 & .030 & .085 & .053 & .031 & .023 & .041 & -017 & -194 & .295 \\
\hline \multirow[t]{10}{*}{ Ant-image Correlation } & $\begin{array}{l}\text { proporcao de domicilios } \\
\text { com rede geral de água }\end{array}$ & $.783^{\circ}$ &,- 636 &,- 206 & .038 & .050 &,- 046 & -050 & -014 &,- 076 & .242 \\
\hline & $\begin{array}{l}\text { proporcao de domicilios } \\
\text { com rede geral de água } \\
\text { (em um cómodo) }\end{array}$ & ,636 & $.765^{\circ}$ & .032 & .063 & .095 & .021 & .023 & -129 & $\cdot, 075$ & .087 \\
\hline & $\begin{array}{l}\text { proporcao de domicilios } \\
\text { com rede geral de esgoto }\end{array}$ & -206 & .032 & $.920^{\circ}$ & -.170 & -083 & -207 &,- 040 & .039 & -.087 & .229 \\
\hline & $\begin{array}{l}\text { proporcao de domicilios } \\
\text { com coleta de lixo }\end{array}$ & .038 & .063 &,- 170 & $.889^{\circ}$ & .023 & -290 & -097 & .023 &,- 023 & .121 \\
\hline & $\begin{array}{l}\text { renda media do chefe de } \\
\text { domicilio em sm }\end{array}$ & .050 & .095 & -083 & .023 & $.741^{\mathrm{a}}$ & .198 & .169 & -848 & -169 & .164 \\
\hline & $\begin{array}{l}\text { proporcao de chefes } \\
\text { alfabetizados }\end{array}$ &., 046 & .021 & .207 & , 290 & .198 & $.865^{\circ}$ & -127 & - 487 & -019 & .084 \\
\hline & $\begin{array}{l}\text { proporcao de chefes com } \\
\text { ensino fundamental } \\
\text { completo }\end{array}$ & -050 &,- 023 &., 040 & -097 & 169 &,- 127 & $.664^{\circ}$ & .005 &,- 154 & .084 \\
\hline & $\begin{array}{l}\text { anos medios de estudo } \\
\text { do chefe }\end{array}$ & -014 & -129 & .039 & .023 &,- 848 & -487 & .005 & $.734^{3}$ & .269 &,- 106 \\
\hline & Habitantes por Domic而的s & -,076 &,- 075 &,- 087 &,- 023 & -169 &,- 019 &,- 154 & 269 & $.802^{\mathrm{a}}$ &,- 543 \\
\hline & $\begin{array}{l}\text { proporcao de criancas de } \\
\text { Oa } 4 \text { anos por setor }\end{array}$ &, 242 & .087 & ,229 & .121 & .164 & ,084 & , 084 & , 106 & -543 &, $849^{3}$ \\
\hline
\end{tabular}

Communalities

\begin{tabular}{|l|r|r|}
\hline & \multicolumn{1}{|c|}{ Initial } & Extraction \\
\hline $\begin{array}{l}\text { proporcao de domicilios } \\
\text { com rede geral de água } \\
\text { proporcao de domicilios } \\
\text { com rede geral de água } \\
\text { (em um cômodo) }\end{array}$ & 1,000 &, 865 \\
$\begin{array}{l}\text { proporcao de domicilios } \\
\text { com rede geral de esgoto } \\
\text { proporcao de domicilios } \\
\text { com coleta de lixo }\end{array}$ & 1,000 &, 846 \\
$\begin{array}{l}\text { renda media do chefe de } \\
\text { domicilio em sm } \\
\text { proporcao de chefes }\end{array}$ & 1,000 &, 638 \\
$\begin{array}{l}\text { alfabetizados } \\
\text { proporcao de chefes com } \\
\text { ensino fundamental } \\
\text { completo } \\
\text { anos medios de estudo } \\
\text { do chefe }\end{array}$ & 1,000 \\
Habitantes por Domicilios & 1,000 &, 814 \\
$\begin{array}{l}\text { proporcao de criancas de } \\
0 \text { a } 4 \text { anos por setor }\end{array}$ & 1,000 &, 725 \\
\hline
\end{tabular}

Extraction Method: Principal Component Analysis. 


\begin{tabular}{|c|c|c|c|c|c|c|c|c|c|c|c|}
\hline \multicolumn{12}{|c|}{ Reproduced Correlations } \\
\hline & & \begin{tabular}{|c|} 
proporcao de \\
domicilios \\
con rede \\
geral de água \\
\end{tabular} & \begin{tabular}{|c|} 
proporcao de \\
domicilios \\
com rede \\
geral de \\
água (ern um \\
cômodo) \\
\end{tabular} & \begin{tabular}{|c} 
proporcao de \\
domicilios \\
com rede \\
geral de \\
esgoto
\end{tabular} & $\begin{array}{c}\text { proporcao de } \\
\text { domicilios } \\
\text { com coleta } \\
\text { de lixo }\end{array}$ & $\begin{array}{l}\text { renda media } \\
\text { do chefe de } \\
\text { domiclio em } \\
\text { sm }\end{array}$ & $\begin{array}{l}\text { proporcao de } \\
\text { chefes } \\
\text { alfabetizados }\end{array}$ & $\begin{array}{l}\text { proporcao de } \\
\text { chefes com } \\
\text { ensino } \\
\text { fundamental } \\
\text { completo }\end{array}$ & $\begin{array}{l}\text { anos medios } \\
\text { de estudo do } \\
\text { chefe }\end{array}$ & $\begin{array}{l}\text { Habitantes } \\
\text { por } \\
\text { Domicilios }\end{array}$ & $\begin{array}{c}\text { proporcao de } \\
\text { criancas de } 0 \\
\text { a } 4 \text { anos por } \\
\text { setor }\end{array}$ \\
\hline \multirow[t]{10}{*}{ Reproduced Correlation } & $\begin{array}{l}\text { proporcao de domicilios } \\
\text { com rede geral de água }\end{array}$ & $.865^{b}$ & .846 & .568 & 2223 & .310 & .461 & .191 & ,392 &,- 333 &.,- 629 \\
\hline & $\begin{array}{l}\text { proporcao de donicilios } \\
\text { com rede geral de água } \\
\text { (em um cômodo) }\end{array}$ & 846 & $846^{\mathrm{b}}$ & .488 & .107 & .256 & 369 & 132 & .328 &,- 288 &,- 565 \\
\hline & $\begin{array}{l}\text { proporcao de domicilios } \\
\text { com rede geral de esgoto }\end{array}$ &, 568 & 488 & $.638^{\mathrm{b}}$ &, 540 &, 502 & .667 & .192 & .578 &,- 457 & -.652 \\
\hline & $\begin{array}{l}\text { proporcao de domicilios } \\
\text { com coleta de lixo }\end{array}$ & .223 & .107 & .540 & $.705^{b}$ &, 371 & .610 & .354 & .439 &,- 318 & -.459 \\
\hline & $\begin{array}{l}\text { renda media do chefe de } \\
\text { donicilio en sm }\end{array}$ & .310 & 256 & .502 & .371 & $814^{b}$ & 693 &,- 350 & 834 &,- 676 &,- 634 \\
\hline & $\begin{array}{l}\text { proporcao de chefes } \\
\text { alfabetizados }\end{array}$ & .461 &, 369 & .667 & .610 & .693 & $.783^{\mathrm{b}}$ &, 036 & .756 &,- 597 & -.709 \\
\hline & $\begin{array}{l}\text { proporcao de chefes com } \\
\text { ensino tundamental } \\
\text { completo }\end{array}$ & 191 & .132 & .192 & ,354 &,- 350 & 036 & $.725^{\mathrm{b}}$ &,- 280 & 256 &,- 011 \\
\hline & $\begin{array}{l}\text { anos medios de estudo } \\
\text { do chete }\end{array}$ & 392 & .328 & .578 & 439 & 834 & .756 & -280 & $866^{b}$ &,- 701 & -.701 \\
\hline & Habitartes por Domicilios &,- 333 & -288 & -457 &,- 318 & -.676 & -597 & .256 & -701 & $.570^{\mathrm{b}}$ & .567 \\
\hline & $\begin{array}{l}\text { proporcao de criancas de } \\
0 \text { a } 4 \text { anos por setor }\end{array}$ &,- 629 &,- 565 &,- 652 & -.459 &,- 634 & -709 &,- 011 &,- 701 & .567 & $.726^{\mathrm{b}}$ \\
\hline \multirow[t]{10}{*}{ Residual a } & $\begin{array}{l}\text { proporcao de donicilios } \\
\text { com rede geral de água }\end{array}$ & &,- 085 & -022 & ,051 &, 002 & $-5,35 E-005$ & -.050 &,- 004 & ,030 &, 036 \\
\hline & $\begin{array}{l}\text { proporcao de domicilios } \\
\text { comn rede geral de água } \\
\text { (em um cốmodo) }\end{array}$ &,- 085 & &,- 069 &, 086 & .022 & 019 & -.021 & .030 & .040 & .075 \\
\hline & $\begin{array}{l}\text { proporcao de domicilios } \\
\text { com rede geral de esgogoto }\end{array}$ &,- 022 &,- 069 & &,- 069 & -.025 & -0.044 & -102 &,- 054 & .078 & .029 \\
\hline & $\begin{array}{l}\text { proporcao de domicilios } \\
\text { com coleta de lixo }\end{array}$ & ,051 & .086 &,- 069 & &,- 058 & -.071 & -.215 &,- 064 &, 032 & .026 \\
\hline & $\begin{array}{l}\text { renda media do chete de } \\
\text { donicilio en sm }\end{array}$ & .002 & .022 & -.025 & -058 & &,- 024 & .107 & .093 & .147 & .075 \\
\hline & $\begin{array}{l}\text { proporcao de chetes } \\
\text { alfabetizados }\end{array}$ & $-5,35 E-005$ & .019 & -044 & -.071 &,- 024 & & ,002 & .026 & .083 & ,081 \\
\hline & $\begin{array}{l}\text { proporcao de chetes com } \\
\text { ensino fundamental } \\
\text { completo }\end{array}$ &,- 050 &,- 021 & -102 &,- 215 & .107 & .002 & & .103 & -097 & $-0,013$ \\
\hline & $\begin{array}{l}\text { anos medios de estudo } \\
\text { do chefe }\end{array}$ &,- 004 & .030 &,- 054 &,- 064 & .093 & .026 & .103 & & ,099 & 091 \\
\hline & Habitantes por Donicilios &, 030 & .040 & .078 & 032 & .147 & 083 &,- 097 & .099 & & .115 \\
\hline & $\begin{array}{l}\text { proporcao de criancas de } \\
\text { 0 a } 4 \text { anos por setor }\end{array}$ & ,036 & .075 & .029 & .026 & .075 & 081 &,- 013 & .091 & .115 & \\
\hline
\end{tabular}

Extraction Method: Principal Component Analysis.

b. Reproduced communalties

Rotated Component Matrī̄

\begin{tabular}{|c|c|c|c|}
\hline & \multicolumn{3}{|c|}{ Component } \\
\hline & 1 & 2 & 3 \\
\hline $\begin{array}{l}\text { proporcao de domicilios } \\
\text { com rede geral de água }\end{array}$ & &, 885 & \\
\hline $\begin{array}{l}\text { proporcao de domicilios } \\
\text { com rede geral de água } \\
\text { (em um cômodo) }\end{array}$ & & 904 & \\
\hline $\begin{array}{l}\text { proporcao de domicilios } \\
\text { com rede geral de esgoto }\end{array}$ &, 553 & .424 &, 390 \\
\hline $\begin{array}{l}\text { proporcao de domicilios } \\
\text { com coleta de lixo }\end{array}$ & 498 & & .676 \\
\hline $\begin{array}{l}\text { renda media do chefe de } \\
\text { domicilio ern sm }\end{array}$ &, 887 & & \\
\hline $\begin{array}{l}\text { proporcao de chefes } \\
\text { alfabetizados }\end{array}$ & 784 & &, 324 \\
\hline $\begin{array}{l}\text { proporcao de chefes com } \\
\text { ensino fundamental } \\
\text { completo }\end{array}$ &,- 328 & &, 766 \\
\hline $\begin{array}{l}\text { anos medios de estudo } \\
\text { do chefe }\end{array}$ & 909 & & \\
\hline Habitantes por Domicilios &,- 728 & & \\
\hline $\begin{array}{l}\text { proporcao de criancas de } \\
0 \text { a } 4 \text { anos por setor }\end{array}$ &,- 668 &,- 496 & \\
\hline
\end{tabular}

Extraction Method: Principal Component Analysis.

Rotation Method: Varimax with Kaiser Normalization.

a. Rotation converged in 5 iterations. 
Component Transformation Matrix

\begin{tabular}{|l|r|r|r|}
\hline Component & \multicolumn{1}{|c|}{1} & \multicolumn{1}{|c|}{2} & \multicolumn{1}{l|}{3} \\
\hline 1 &, 839 &, 500 &, 214 \\
2 &,- 521 &, 627 &, 579 \\
3 &, 155 &,- 597 &, 787 \\
\hline
\end{tabular}

Extraction Method: Principal Component Analysis.

Rotation Method: Varimax with Kaiser Normalization.

\begin{tabular}{|c|c|c|c|}
\hline \multicolumn{4}{|c|}{ Rotated Component Matrī̄ } \\
\hline & \multicolumn{3}{|c|}{ Component } \\
\hline & 1 & 2 & 3 \\
\hline $\begin{array}{l}\text { proporcao de domicilios } \\
\text { com rede geral de água }\end{array}$ & & 885 & \\
\hline $\begin{array}{l}\text { proporcao de domicilios } \\
\text { com rede geral de água } \\
\text { (em um cômodo) }\end{array}$ & &, 904 & \\
\hline $\begin{array}{l}\text { proporcao de domicilios } \\
\text { com rede geral de esgoto }\end{array}$ &, 553 & .424 &, 390 \\
\hline $\begin{array}{l}\text { proporcao de domicilios } \\
\text { com coleta de lixo }\end{array}$ & .498 & & .676 \\
\hline $\begin{array}{l}\text { renda media do chefe de } \\
\text { domicilio em sm }\end{array}$ &, 887 & & \\
\hline $\begin{array}{l}\text { proporcao de chefes } \\
\text { alfabetizados }\end{array}$ &, 784 & &, 324 \\
\hline $\begin{array}{l}\text { proporcao de chefes com } \\
\text { ensino fundamental } \\
\text { completo }\end{array}$ &,- 328 & &, 766 \\
\hline $\begin{array}{l}\text { anos medios de estudo } \\
\text { do chefe }\end{array}$ & 909 & & \\
\hline Habitantes por Domicilios &,- 728 & & \\
\hline $\begin{array}{l}\text { proporcao de criancas de } \\
0 \text { a } 4 \text { anos por setor }\end{array}$ &,- 668 &,- 496 & \\
\hline
\end{tabular}

Extraction Method: Principal Component Analysis.

Rotation Method: Varimax with Kaiser Normalization.

a. Rotation converged in 5 iterations.

\section{Component Plot in Rotated Space}

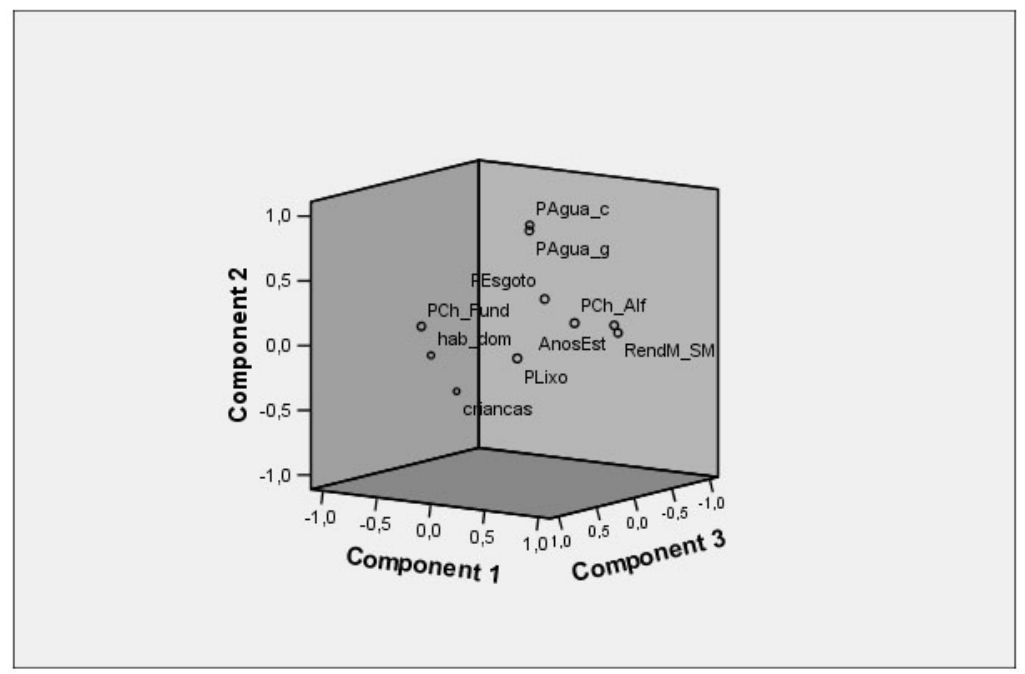


Outputs - TwoStep cluster

Cluster Distribution

\begin{tabular}{|ll|r|r|r|}
\hline & & $\mathrm{N}$ & $\begin{array}{c}\text { \% of } \\
\text { Combined }\end{array}$ & \% of Total \\
\hline Cluster & 1 & 46 & $30,5 \%$ & $29,3 \%$ \\
& 2 & 73 & $48,3 \%$ & $46,5 \%$ \\
& 3 & 9 & $6,0 \%$ & $5,7 \%$ \\
& 4 & 22 & $14,6 \%$ & $14,0 \%$ \\
& Outlier (-1) & 1 &, $7 \%$ &, $6 \%$ \\
Excluded Cases & Combined & 151 & $100,0 \%$ & $96,2 \%$ \\
Total & & 157 & & $3,8 \%$ \\
& & & & $100,0 \%$ \\
\hline
\end{tabular}

\section{Cluster Profile}

Frequencies

\section{Centroids}

\begin{tabular}{|c|c|c|c|c|c|c|c|}
\hline & \multicolumn{2}{|c|}{$\begin{array}{c}\text { REGR factor score } 1 \text { for } \\
\text { analysis } 2\end{array}$} & \multicolumn{2}{|c|}{$\begin{array}{c}\text { REGR factor score } 2 \text { for } \\
\text { analysis } 2\end{array}$} & \multicolumn{2}{|c|}{$\begin{array}{c}\text { REGR factor score } 3 \text { for } \\
\text { analysis } 2\end{array}$} \\
\hline & & Mean & Std. Deviation & Mean & Std. Deviation & Mean & Std. Deviation \\
\hline \multirow[t]{7}{*}{ Cluster } & 1 & 1,0655096 & 65964882 & ,0620849 & ,29266169 &,- 5513499 & ,47762068 \\
\hline & 2 & -,1631957 & 47858315 & 2650386 & 27075811 & 6929761 & 42925314 \\
\hline & 3 &,- 6479587 & 1,00557689 & 3,4346662 & 1,50284065 &,- 1559872 & 1,29940587 \\
\hline & 4 & $12851538^{-}$ & 35082543 & 2970037 & 47075294, & -,7916104 & 65031333 \\
\hline & Outlier (-1) & - & & 21741934 & & & \\
\hline & Combined & 2,9951498 & 1 & ( & חתמחמחתחת 1 & 6,405846 & 1 \\
\hline & & ,0000000 & 1,00000000 & ,0000000 & $\perp, 0000000$ & , & 1,00000000 \\
\hline
\end{tabular}

\section{Attribute Importance}

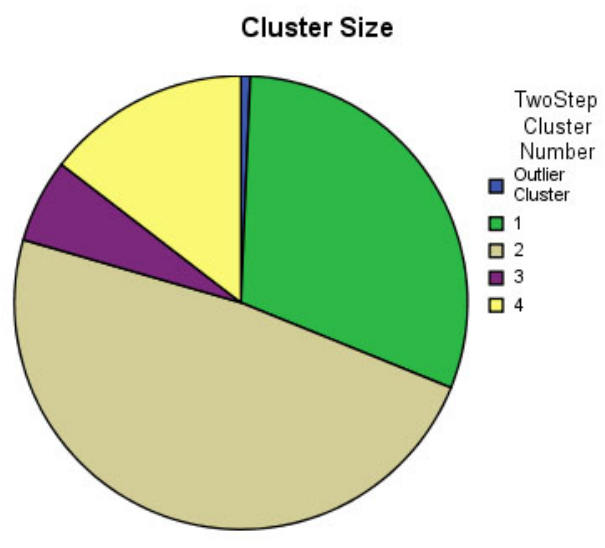


Within Cluster Variation

Simultaneous $95 \%$ Confidence Intervals for Means

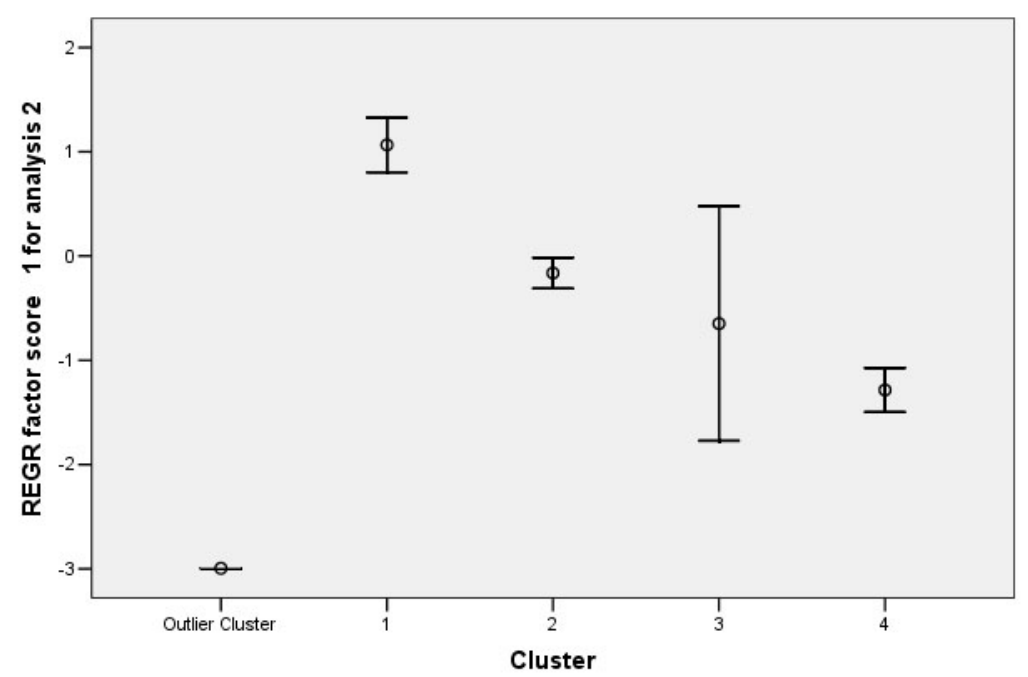

Simultaneous $95 \%$ Confidence Intervals for Means

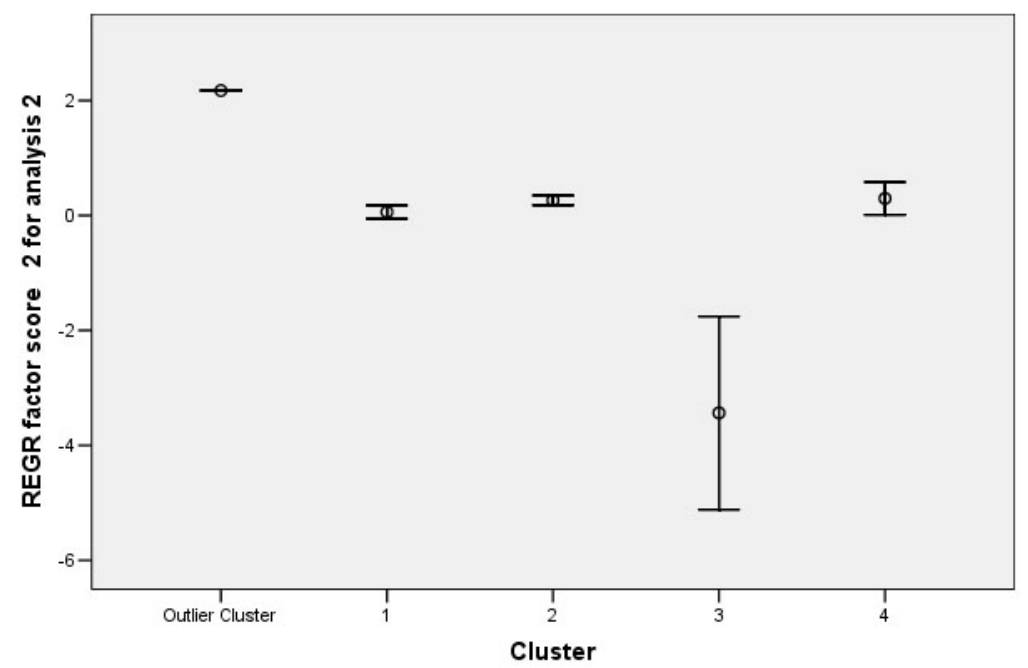




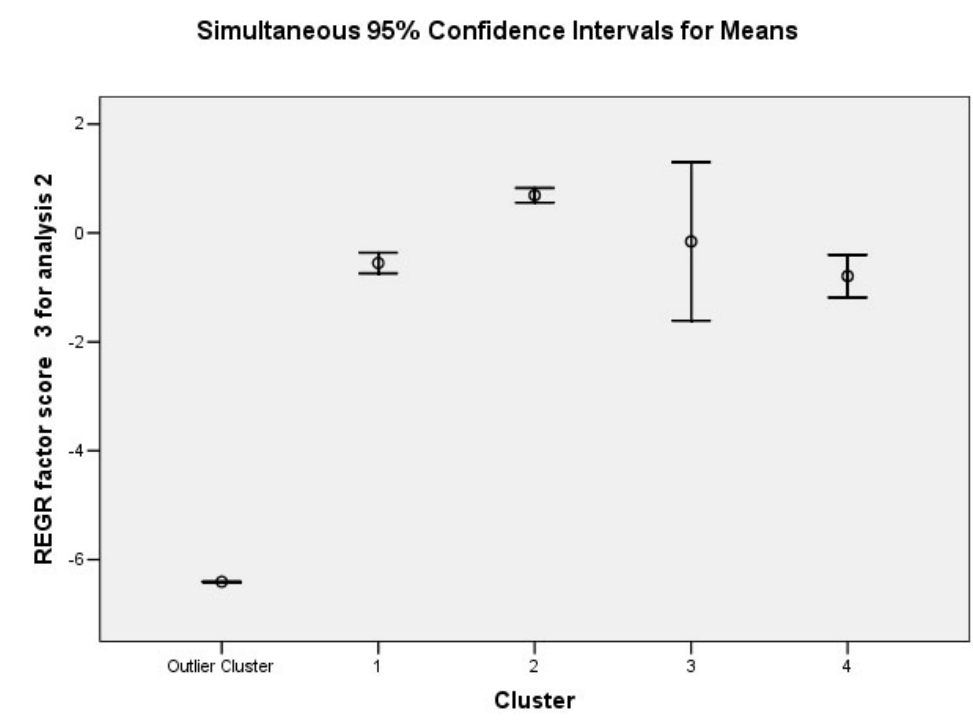

Outputs - TwoStep cluster

\section{Cluster Distribution}

\begin{tabular}{|rl|r|r|r|}
\hline & & $\mathrm{N}$ & $\begin{array}{r}\text { \% of } \\
\text { Combined }\end{array}$ & \% of Total \\
\hline Cluster & 1 & 11 & $28,2 \%$ & $28,2 \%$ \\
& 2 & 10 & $25,6 \%$ & $25,6 \%$ \\
& 3 & 9 & $23,1 \%$ & $23,1 \%$ \\
& 4 & 9 & $23,1 \%$ & $23,1 \%$ \\
& Combined & 39 & $100,0 \%$ & $100,0 \%$ \\
Total & & 39 & & $100,0 \%$ \\
\hline
\end{tabular}

\section{Cluster Profile}

Frequencies

set_cluste

\begin{tabular}{|c|c|c|c|c|c|c|c|c|c|}
\hline & & \multicolumn{2}{|c|}{1} & \multicolumn{2}{|c|}{2} & \multicolumn{2}{|c|}{3} & \multicolumn{2}{|c|}{4} \\
\hline & & Frequency & Percent & Frequency & Percent & Frequency & Percent & Frequency & Percent \\
\hline \multirow[t]{5}{*}{ Cluster } & 1 & 11 & $100,0 \%$ & 0 & ,0\% & 0 & ,0\% & 0 &, $0 \%$ \\
\hline & 2 & 0 &, $0 \%$ & 9 & $50,0 \%$ & 0 &, $0 \%$ & 1 & $12,5 \%$ \\
\hline & 3 & 0 &, $0 \%$ & 9 & $50,0 \%$ & 0 &, $0 \%$ & 0 &, $0 \%$ \\
\hline & 4 & 0 &, $0 \%$ & 0 &, $0 \%$ & 2 & $100,0 \%$ & 7 & $87,5 \%$ \\
\hline & Combined & 11 & $100,0 \%$ & 18 & $100,0 \%$ & 2 & $100,0 \%$ & 8 & $100,0 \%$ \\
\hline
\end{tabular}


cluster_zr

\begin{tabular}{|c|c|c|c|c|c|c|c|c|c|}
\hline & & \multicolumn{2}{|l|}{1} & \multicolumn{2}{|l|}{2} & \multicolumn{2}{|c|}{3} & \multicolumn{2}{|c|}{4} \\
\hline & & Frequency & Percent & Frequency & Percent & Frequency & Percent & $\begin{array}{l}\text { Frequ } \\
\text { ency }\end{array}$ & Percent \\
\hline \multirow{5}{*}{$\begin{array}{l}\text { Cluste } \\
r\end{array}$} & 1 & 4 & $66,7 \%$ & 7 & $58,3 \%$ & 0 &, $0 \%$ & 0 &, $0 \%$ \\
\hline & 2 & 2 & $33,3 \%$ & 5 & $41,7 \%$ & 3 & $100,0 \%$ & 0 &, $0 \%$ \\
\hline & 3 & 0 &, $0 \%$ & 0 &, $0 \%$ & 0 &, $0 \%$ & 9 & $50,0 \%$ \\
\hline & 4 & 0 &, $0 \%$ & 0 &, $0 \%$ & 0 &, $0 \%$ & 9 & $50,0 \%$ \\
\hline & $\begin{array}{l}\text { Combine } \\
\text { d }\end{array}$ & 6 & $100,0 \%$ & 12 & $100,0 \%$ & 3 & $100,0 \%$ & 18 & $100,0 \%$ \\
\hline
\end{tabular}

\section{Cluster Size}

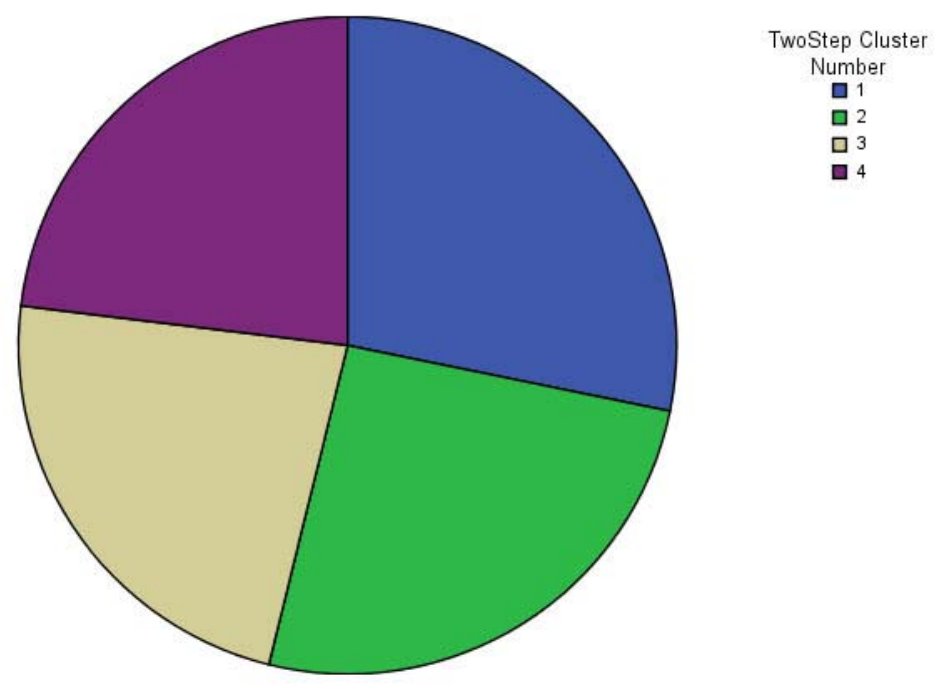

